\author{
UNIVERSIDADE DE SÃO PAULO - USP \\ FACULDADE DE ECONOMIA, ADMINISTRAÇÃO E CONTABILIDADE \\ DEPARTAMENTO DE ECONOMIA \\ PROGRAMA DE PÓS-GRADUAÇÃO EM ECONOMIA
}

\title{
Distribuição de Riqueza e Atividade Econômica: Uma Extensão Kaleckiana
}

Eduardo Lederman Rawet

Orientador: Laura Barbosa de Carvalho

São Paulo, Brasil

2018 
Prof. Dr. Vahan Agopyan

Reitor da Universidade de São Paulo

Prof. Dr. Adalberto Américo Fischmann

Diretor da Faculdade de Economia, Administração e Contabilidade

Prof. Dr. Eduardo Amaral Haddad

Chefe do Departamento de Economia

Prof. Dr. Ariaster Baumgratz Chimeli

Coordenador do Programa de Pós-Graduação em Economia 
EDUARDO LEDERMAN RAWET

\title{
Distribuição de Riqueza e Atividade Econômica: Uma Extensão Kaleckiana
}

\begin{abstract}
Dissertação apresentada ao Departamento de Economia da Faculdade de Economia, Administração e Contabilidade da Universidade de São Paulo como requisito parcial para a obtenção do título de Mestre em Ciências.
\end{abstract}

Orientador: Laura Barbosa de Carvalho

\section{Versão Corrigida}

(versão original disponível na Faculdade de Economia, Administração e Contabilidade)

São Paulo, Brasil 
FICHA CATALOGRÁFICA

Elaborada por Rafael Mielli Rodrigues - CRB-8/7286

Seção de Processamento Técnico do SBD/FEA/USP

Rawet, Eduardo Lederman

Distribuição de riqueza e atividade econômica: uma extensão

kaleckiana / Eduardo Lederman Rawet. - São Paulo, 2018.

$120 \mathrm{p}$.

Dissertação (Mestrado) - Universidade de São Paulo, 2018.

Orientador: Laura Barbosa de Carvalho.

1. Macroeconomia 2. Economia keynesiana 3. Riqueza I. Universidade de São Paulo. Faculdade de Economia, Administração e Contabilidade. II. Título.

CDD - 339 


\title{
Distribuição de Riqueza e Atividade Econômica: Uma Extensão Kaleckiana
}

\author{
Dissertação apresentada ao Departamento de \\ Economia da Faculdade de Economia, Admi- \\ nistração e Contabilidade da Universidade de \\ São Paulo como requisito parcial para a ob- \\ tenção do título de Mestre em Ciências.
}

Trabalho aprovado. São Paulo, Brasil, de de 2018:

Laura Barbosa de Carvalho

Orientadora

Gilberto Tadeu Lima

Antônio Carlos Macedo e Silva

Fábio Neves Perácio de Freitas

São Paulo, Brasil

2018 

Dedico este trabalho à memória de Maria Regina, que cuidou de mim durante mais da metade da minha vida como se fosse um filho. 



\section{Agradecimentos}

Agradeço a minha família, por todo apoio financeiro e psicológico que me deram durante toda a minha vida. Sem dúvidas as idas para o Rio, onde eu me sentia acolhido por todos, foram essenciais para que eu pudesse relaxar e estudar com toda a calma e tranquilidade que é preciso. Agradeço especialmente a meu pai, Raul Rawet, que durante todo o processo em que escrevi a dissertação, leu o trabalho inúmeras vezes, revisando e sugerindo alterações nos textos.

Agradeço à Fundação Instituto de Pesquisas Econômicas (FIPE) pelo auxilio financeiro que foi dado no início deste projeto e à Fundação de Amparo a Pesquisa do Estado de São Paulo (FAPESP), pelo apoio financeiro no restante do tempo, nos processos $\mathrm{n}^{\circ}$ 2017/14763-7 e n o 2016/18755-6.

À todos os professores que tive, tanto na graduação como na pós graduação, pois todos foram únicos na minha formação acadêmica

Agradeço ao professor Marc Lavoie, que no meu período na França me deu todo o apoio e orientação, oferecendo reflexões sobre o encaminhamento do trabalho, além de dar uma formação acadêmica que vou levar para sempre. Também agradeço aos amigos de Paris, a vida lá não seria a mesma sem vocês.

À todos os amigos do Rio, que entenderam e respeitaram a dificuldade de morar em outra cidade e abrindo a agenda sempre que eu poderia fazer uma visita.

Agradeço a kvutzá de São Paulo, a vinda para cá e as horas de estudo foram infinitamente mais fáceis com a presença constante de vocês. Seria impossível terminar essa dissertação sem os necessários momentos de relaxamento que vocês proporcionaram.

Agradeço enormemente aos amigos que fiz no mestrado. O apoio e a companhia tornou o mestrado extremamente especial. Agradeço especialmente ao eterno amigo de todas as horas, literalmente, Adriano. Sem dúvidas os monólogos, as dúvidas, as inquietações e os medos foram devidamente compartilhados e aliviados durante esses mais de 2 anos de mestrado. Essa dissertação não teria saído sem a sua intensa ajuda.

Ao grupo dos heterodoxos, com nossas reuniões constantes e encontros no corredor que contribuíram muito para feitura desta dissertação, em especial à Gilberto Lima e Fernando Rugitsky, pela participação nas bancas de qualificação e avaliação de progresso.

Agradeço também aos anônimos: trabalhadores e trabalhadoras do bandejão, motoristas de ônibus, faxineiras, secretaria e pessoal de infraestrutura.

Por fim, agradeço especialmente à minha orientadora, Laura Carvalho, que me 
orientou toda a dedicação. Acompanhou de perto todo o desenvolvimento da dissertação, contribuindo não apenas academicamente, sugerindo caminhos e reflexões, como também revisando cada palavra que está nesta dissertação (a responsabilidade ainda é minha). Muito obrigado! 
"Limitar-se à racionalidade formal (concernente aos meios) é vocação do tecnocrata. Mas ignorar que essa racionalidade existe e que é independente dos juízos de valor com respeito aos fins é fechar a porta ao avanço da ciência social. Combater esta simplesmente porque pode ser eficaz nas mãos daqueles que têm objetivo de consolidar as estruturas sociais que não aprovamos é desconhecer que, para construir novas estruturas, ela não é menos indispensável."Furtado (2013)[p. 48] 



\section{Resumo}

No contexto em que a distribuição de riqueza fica cada vez mais concentrada nas mãos dos mais ricos (Piketty (2014)), torna-se essencial incluir a riqueza e a sua distribuição no estudo dos determinantes da atividade econômica. Assim, dentro de um arcabouço Kaleckiano com modelagem stock-flow-consistent, essa dissertação busca entender como o grau de utilização de capacidade das firmas se relaciona com a distribuição de renda e riqueza. Trabalhos na tradição pós-Keynesiana já haviam buscado entender essas relações, primeiro em Kaldor (1955) e Pasinetti (1962), na literatura neo-Keynesiana, e posteriormente em Dutt (1990) e Palley (2012), na literatura Kaleckiana. A principal inovação desta dissertação é incluir a acumulação de riqueza por trabalhadores e capitalistas, eliminando porém a possibilidade de trabalhadores acumularem estoque de capital físico.

O modelo desenvolvido possui três classes, duas de trabalhadores que dividem a massa de salários, e uma de capitalistas, que recebe os lucros. Uma das classes de trabalhadores é mais qualificada, recebe um salário mais elevado e tem propensão a consumir sobre a renda disponível menor que a unidade. Assim como os capitalistas, que também têm propensão a poupar positiva sobre a renda disponível, a classe dos trabalhadores mais qualificados acumula riqueza na forma de títulos públicos, que rendem juros, e moeda. Além disso, ambas as classes têm propensão a consumir positiva sobre o estoque de riqueza financeira.

No modelo, a riqueza impacta a demanda agregada por quatro canais: i) consumo sobre a riqueza; ii) gasto do governo sobre a riqueza tributada; consumo sobre a renda financeira; gasto do governo sobre a renda financeira tributada.

No curto prazo valem o paradoxo dos custos e o paradoxo da poupança, e uma maior proporção da riqueza dos trabalhadores mais qualificados na distribuição de riqueza financeira eleva a utilização de capacidade. No longo prazo, os resultados sugerem que uma maior parcela dos trabalhadores na distribuição de riqueza está associada, na maioria dos casos, com uma menor utilização de capacidade. Além disso, o paradoxo dos custos e o paradoxo da poupança também deixam de valer, a despeito do modelo ser liderado pela demanda.

Palavras-chaves: kaleckiano, modelo kaleckiano, riqueza, Distribuição de Riqueza, crescimento econômico 



\section{Abstract}

In a context in which wealth is increasly more concentrated Piketty (2014), it becomes essential to include this variable and its distribution to study the economic activity. Thus, in a Kaleckian approach with Stock Flow Consistent modelling, this thesis aims to investigate how the rate of utilization of capacity of firms related with income and wealth distributions. Papers aligned with post-Keynesian tradition has already shown attempts to understand these relations, first by Kaldor (1955) and Pasinetti (1962), in neo-Keynesian approach, and more recently by Dutt (1990) and Palley (2012), in Kaleckian literature. The main in innovation of this thesis is to propose the inclusion the accumulation on financial wealth by workers and capitalists, while workers are nor allowed to accumulate capital stock.

The proposed model has three classes, two of workers who share the total wages, and the capitalists, who earn profits. One of workers is high skilled and earns a higher wage. The high skilled workers have a propensity to consume out of disposable income smaller than one. Just like capitalists, who also have a positive propensity to save out of disposable income, high skilled workers accumulate wealth as public bonds, which provide financial income as interest, and as money. Besides that, both classes have a positive propensity to consume out of financial wealth.

Wealth can impact aggregate demand on four ways: i) consumption out of wealth; ii) government expenditure out of wealth taxes; iii) consumption out of financial income; iv) government expenditure out of financial income taxes.

In short run, the paradox of thrift and the paradox of costs hold, while a higher share of high skilled workers' wealth has a positive impact on capacity utilization. In long run, the results suggest that a higher share of high skilled workers wealth has a negative correlation with capacity utilization. Besides that, the paradox of thrift and the paradox of costs do not hold, despite the model is demand-led.

Key-words: Kaleckian, Kaleckian Model, wealth, wealth distribution 



\section{Sumário}

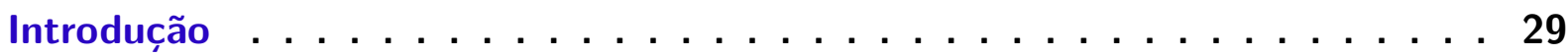

1 Literatura neo-Kaleckiana . . . . . . . . . . . . . . . . . . . . 33

1.1 Literatura Kaleckiana . . . . . . . . . . . . . . . . . . . 33

1.1.1 Desenvolvimento da Literatura . . . . . . . . . . . . . 37

1.1.1.1 Distribuição Pessoal da Renda . . . . . . . . . . . . . . 37

1.2 Riqueza na Literatura Econômica . . . . . . . . . . . . . . . . . . . . . 39

1.2.1 Como a riqueza pode afetar a atividade econômica? . . . . . . . . . 40

1.2.2 A Equação de Cambridge e seus desdobramentos . . . . . . . . . 42

1.2.3 Modelos Kaleckianos com Distribuição de Riqueza . . . . . . . . . . 46

2 Modelo e Solução de Curto Prazo . . . . . . . . . . . . . . . . . . . . 53

2.1 Panorama Geral . . . . . . . . . . . . . . . . . . . . . . . 53

2.2 Modelo. . . . . . . . . . . . . . . . . . . . 56

2.2 .1 Famílias . . . . . . . . . . . . . . . . 56

2.2.1.1 Trabalhadores Menos Qualificados . . . . . . . . 56

2.2.1.2 Trabalhadores Mais Qualificados . . . . . . . . . . 56

2.2.1.3 Capitalistas/Firmas . . . . . . . . . . . . . 57

2.2 .2 Banco Central . . . . . . . . . . . . . . . . . . . . . . . 58

2.2 .3 Governo . . . . . . . . . . . . . . . . . . 58

2.3 Equilíbrio de Curto Prazo . . . . . . . . . . . . . . . . . . 59

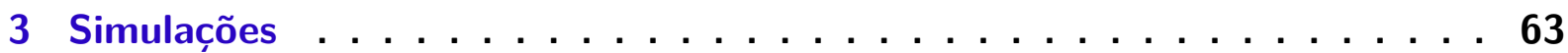

3.1 Introdução . . . . . . . . . . . . . . . . . . 63

3.2 Equações Dinâmicas . . . . . . . . . . . . . . . . . . 65

3.3 Valores Iniciais . . . . . . . . . . . . . . . . . . . . 67

3.4 Simulações . . . . . . . . . . . . . . . . . . . . . . . . . . . 69

3.4.1 Choques em Variáveis Comportamentais . . . . . . . . . 70

3.4.1.1 Propensão a Consumir dos Trabalhadores Mais Qualificados sobre a Renda Disponível . . . . . . . . . . . . . 70

3.4.1.2 Propensão a Consumir dos Capitalistas sobre a Renda Dis-

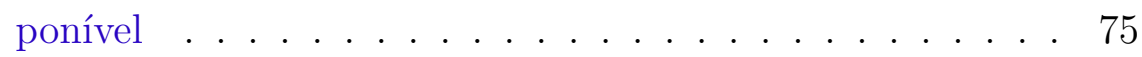

3.4.1.3 Propensão a Consumir dos Trabalhadores Mais Qualificados sobre a Riqueza . . . . . . . . . . . . . . . 80

3.4.1.4 Propensão a Consumir dos Capitalistas sobre a Riqueza . 82

3.4.1.5 Distribuição Funcional da Renda . . . . . . . . . . . . . 84 
3.4.1.6 Distribuição de Salários . . . . . . . . . . . . . . . . . 90

3.4 .2 Política Econômica . . . . . . . . . . . . . . . . . . 9 96

3.4.2.1 Imposto sobre a Riqueza Financeira . . . . . . . . . . 96

3.4.2.2 Taxa de Juros . . . . . . . . . . . . . . . . . . . . . . . . 98

3.4.2.3 Superavit Primário . . . . . . . . . . . . . . . . . . 100

3.5 Discussão . . . . . . . . . . . . . . . . . . . 102

Conclusão . . . . . . . . . . . . . . . . . . . . . . 107

$\begin{array}{ll}\text { Apêndices } & 111\end{array}$

.1 Apêndice. . . . . . . . . . . . . . . . . . . . . . 113

.1 .1 Utilização de Capacidade . . . . . . . . . . . . . . . . . . . 113

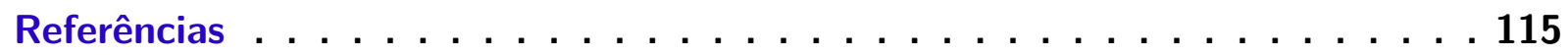




\section{Lista de ilustrações}

Figura 1 - Efeito do aumento de $5 \%$ na propensão a consumir sobre a renda disponível dos trabalhadores mais qualificados $\left(\beta_{h}\right)$ na utilização $\left(u^{*}\right)$ e na proporção da riqueza dos trabalhadores mais qualificados na riqueza financeira total $\left(\varphi_{V}\right) \ldots \ldots \ldots$. . . . . . . . . . . . . . . . . .

Figura 2 - Efeito do aumento de $5 \%$ na propensão a consumir sobre a renda disponível dos trabalhadores mais qualificados $\left(\beta_{h}\right)$ nas fontes de determinação da demanda normalizadas) . . . . . . . . . . . . . . . 72

Figura 3 - Efeito do aumento de $5 \%$ na propensão a consumir sobre a renda disponível dos trabalhadores mais qualificados $\left(\beta_{h}\right)$ na riqueza financeira dos trabalhadores normalizada $\left(v_{h}\right)$ na riqueza financeira dos capitalistas normalizada $\left(v_{c}\right)$ e no crescimento do estoque de capital $\left(g_{k}\right) \ldots$. . .

Figura 4 - Efeito do aumento de $5 \%$ na propensão a consumir sobre a renda disponível dos trabalhadores mais qualificados $\left.\left(\beta_{h}\right)\right)$ na parcela dos trabalhadores na repartição líquida da renda $\left(\varphi_{D L}\right)$ e na taxa de lucros

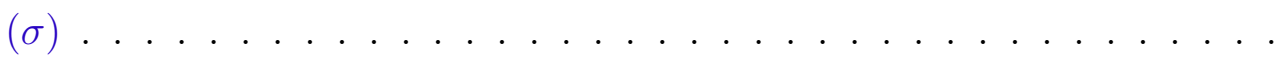

Figura 5 - Efeito do aumento de $5 \%$ na propensão a consumir sobre a renda disponível dos capitalistas $\left(\beta_{c}\right)$ na utilização $\left(u^{*}\right)$ e na proporção da riqueza dos trabalhadores mais qualificados na riqueza financeira total $\left(\varphi_{V}\right)$. .

Figura 6 - Efeito do aumento de $5 \%$ na propensão a consumir sobre a renda disponível dos capitalistas $\left(\beta_{c}\right)$ nas fontes de determinação da demanda normalizadas $\ldots \ldots \ldots \ldots \ldots$. . . . . . . . . . . . .

Figura 7 - Efeito do aumento de $5 \%$ na propensão a consumir sobre a renda disponível dos capitalistas $\left(\beta_{c}\right)$ na riqueza financeira dos trabalhadores normalizada $\left(v_{h}\right)$ na riqueza financeira dos capitalistas normalizada $\left(v_{c}\right)$ e no crescimento do estoque de capital $\left(g_{k, t}\right) \ldots \ldots \ldots$

Figura 8 - Efeito do aumento de $5 \%$ na propensão a consumir sobre a renda disponível dos capitalistas $\left(\beta_{c}\right)$ na parcela dos trabalhadores na repartição líquida da renda $\left(\varphi_{D L}\right)$ e na taxa de lucros $(\sigma) \ldots \ldots \ldots$

Figura 9 - Efeito do aumento de $10 \%$ na propensão a consumir sobre a riqueza dos trabalhadores mais qualificados $\left(\theta_{h}\right)$ na utilização $\left(u^{*}\right)$ e na proporção da riqueza dos trabalhadores mais qualificados na riqueza financeira toral $\left(\varphi_{V}\right) \ldots \ldots \ldots \ldots \ldots \ldots$

Figura 10 - Efeito do aumento de $5 \%$ na propensão a consumir sobre a riqueza dos trabalhadores mais qualificados $\left.\left(\theta_{h}\right)\right)$ na parcela dos trabalhadores na repartição líquida da renda $\left(\varphi_{D L}\right)$ e na taxa de lucros $(\sigma) \ldots . .$. . 
Figura 11 - Efeito do aumento de $10 \%$ na propensão a consumir sobre a riqueza dos capitalistas $\left(\theta_{c}\right)$ na utilização $\left(u^{*}\right)$ e na proporção da riqueza dos trabalhadores mais qualificados na distribuição de riqueza financeira $\left(\varphi_{V}\right) \ldots \ldots \ldots \ldots \ldots \ldots$

Figura 12 - Efeito do aumento de $5 \%$ na propensão a consumir sobre a riqueza dos capitalistas $\left(\theta_{c}\right)$ na parcela dos trabalhadores na repartição líquida da renda $\left(\varphi_{D L}\right)$ e na taxa de lucros $(\sigma) \ldots \ldots . \ldots . \ldots 84$

Figura 13 - Efeito do aumento de $10 \%$ na parcela de salários na renda, $\left(\psi_{W}\right)$, na utilização $\left(u^{*}\right)$ e na proporção da riqueza dos trabalhadores mais qualificados na riqueza financeira total $\left(\varphi_{V}\right) \ldots \ldots$. . . . . . . 85

Figura 14 -Efeito do aumento de $10 \%$ na parcela de salários na renda, $\left(\psi_{W}\right)$, nas fontes de determinação da demanda normalizadas) . . . . . . . . . . . 86

Figura 15 - Efeito do aumento de $10 \%$ na parcela de salários na renda $\left(\psi_{W}\right)$ na riqueza financeira dos trabalhadores normalizada $\left(v_{h}\right)$ na riqueza financeira dos capitalistas normalizada $\left(v_{c}\right)$ e no crescimento do estoque de capital $\left(g_{k}\right) \ldots \ldots \ldots \ldots$. . . . . . . . . . . . . 88

Figura 16 - Efeito do aumento de $10 \%$ na parcela de salários na renda $\left(\psi_{W}\right)$ na parcela dos trabalhadores na repartição líquida da renda $\left(\varphi_{D L}\right)$ e na

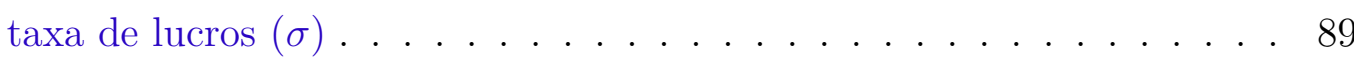

Figura 17 - Efeito do aumento de $10 \%$ na distribuição de salários $\left(\psi_{L}\right)$ na utilização $\left(u^{*}\right)$ e na proporção dos trabalhadores mais qualificados na riqueza financeira total $\left(\varphi_{V}\right) \ldots \ldots \ldots$. . . . . . . . . . . . . 91

Figura 18 - Efeito do aumento de $10 \%$ na distribuição de salários $\left(\psi_{L}\right)$ nas fontes de determinação da demanda normalizadas) . . . . . . . . . . . . . . 92

Figura 19 - Efeito do aumento de $10 \%$ na distribuição de salários $\left(\psi_{L}\right)$ na riqueza financeira dos trabalhadores normalizada $\left(v_{h}\right)$ na riqueza financeira dos capitalistas normalizada $\left(v_{c}\right)$ e no crescimento do estoque de capital $\left(g_{k}\right) 93$

Figura 20 -Efeito do aumento de $10 \%$ na distribuição de salários $\left(\psi_{L}\right)$ na parcela dos trabalhadores na repartição líquida da renda $\left(\varphi_{D L}\right)$ e na taxa de lucros $(\sigma) \ldots \ldots \ldots \ldots$. . . . . . . . . . . . . . . . 94

Figura 21 -Efeito do aumento de $10 \%$ na taxa sobre a riqueza $\left(\tau_{V}\right)$ na utilização $\left(u^{*}\right)$ e na proporção da riqueza dos trabalhadores mais qualificados na riqueza financeira total $\left(\varphi_{V}\right) \ldots \ldots . \ldots . \ldots 96$

Figura 22 - Efeito do aumento de $10 \%$ na taxa sobre a riqueza $\left(\tau_{V, t}\right)$ na parcela dos trabalhadores na repartição de renda líquida $\left(\varphi_{D L, t}\right)$ e na taxa de

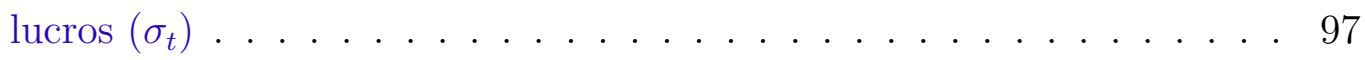

Figura 23 - Efeito do aumento de $10 \%$ na taxa de juros $(r)$ na utilização $\left(u^{*}\right)$ e na proporção dos trabalhadores mais qualificados na distribuição de riqueza financeira $\left(\varphi_{V}\right) \ldots \ldots \ldots$. . . . . . . . . . . . . 98 
Figura 24 - Efeito do aumento de $10 \%$ na taxa de juros $(r)$ na parcela dos trabalhadores na repartição de renda líquida $\left(\varphi_{D L}\right)$ e na taxa de lucros $(\sigma) \ldots \ldots \ldots \ldots \ldots \ldots \ldots$

Figura 25 - Efeito da queda de $10 \%$ no superavit primário $(\omega)$ na utilização $\left(u^{*}\right)$ e na proporção da riqueza dos trabalhadores mais qualificados na distribuição de riqueza financeira $\left(\varphi_{V}\right) \ldots$. . . . . . . . . . . . . 100

Figura 26 - Efeito da queda de $10 \%$ no superavit primário $(\omega)$ na parcela dos trabalhadores na repartição de renda líquida $\left(\varphi_{D L}\right)$ e na taxa de lucros

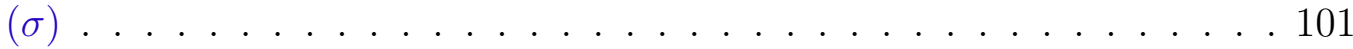





\section{Lista de tabelas}

Tabela 1 - Matriz de Balanços . . . . . . . . . . . . . . . 54

Tabela 2 - Efeito de choques nas varáveis exógenas na utilização . . . . . . . . . 60

Tabela 3 - Parâmetros Exógenos ................... 69

Tabela 4 - Valores Iniciais . . . . . . . . . . . . . . . . . . 69

Tabela 5 - Efeito de choques das varáveis exógenas na utilização, u*, na proporção da riqueza dos trabalhadores mais qualificados na riqueza financeira total, $\varphi_{V, t}$ e na proporção dos trabalhadores na repartição líquida da renda, $\psi_{D L, t} \ldots \ldots \ldots \ldots$. . . . . . . . . . . . . . . . . . . . . . . . .

Tabela 6 - Efeito de políticas Estatais na utilização, u* $^{*}$, na proporção da riqueza dos trabalhadores mais qualificados na riqueza financeira total, $\varphi_{V, t}$ e na parcela dos trabalhadores na repartição líquida da renda, $\psi_{L D, t}$. . . 104 



\section{Lista de símbolos}

$B_{c, t} \quad$ Títulos públicos detidos pelos capitalistas

$B_{c b, t} \quad$ Títulos públicos na posse do Banco Central

$B_{h, t} \quad$ Títulos públicos detidos pelos trabalhadores mais qualificados

$B_{s, t} \quad$ Títulos públicos emitidos pelo governo

$b_{c, t} \quad$ Títulos públicos detidos pelos capitalistas no período t normalizados pelo estoque de capital do período anterior

$b_{c b, t} \quad$ Títulos públicos na posse do Banco Central no período t normalizados pelo estoque de capital do período anterior

$b_{h, t} \quad$ Títulos públicos detidos pelos trabalhadores mais qualificados no período t normalizados pelo estoque de capital do período anterior.

$b_{s, t} \quad$ Títulos públicos emitidos pelo governo no período t normalizados pelo estoque de capital do período anterior

$C_{c, t} \quad$ Consumo dos capitalistas no período $t$

$C_{h, t} \quad$ Consumo dos trabalhadores mais qualificados no período t

$C_{l, t} \quad$ Consumo dos trabalhadores menos qualificados no período $\mathrm{t}$

$D A \quad$ Demanda agregada

$g_{k, t} \quad$ Taxa de acumulação de capital (taxa de crescimento)

$G_{t} \quad$ Gasto do governo

$I_{t} \quad$ Investimento

$K_{t} \quad$ Estoque de capital

$L_{h, t} \quad$ Trabalhadores mais qualificados

$L_{l, t} \quad$ Trabalhadores menos qualificados

$D_{c, t} \quad$ Moeda detida pelos capitalistas

$D_{h, t} \quad$ Moeda detida pelos trabalhadores mais qualificados

$r_{t} \quad$ Taxa de Juros 


\begin{tabular}{|c|c|}
\hline$S_{c, t}$ & Poupança dos capitalistas \\
\hline$S_{h, t}$ & Poupança dos trabalhadores mais qualificados \\
\hline$T_{t}$ & Tributação \\
\hline$u$ & Nível de utilização de capacidade ou utilização \\
\hline$v$ & Razão estoque de capital e produto de plena capacidade \\
\hline$v_{c, t}$ & $\begin{array}{l}\text { Riqueza financeira dos capitalistas no período t normalizada pelo esto- } \\
\text { que de capital do período anterior }\end{array}$ \\
\hline$v_{h, t}$ & $\begin{array}{l}\text { Riqueza financeira dos trabalhadores mais qualificados no período t } \\
\text { normalizada pelo estoque de capital do período anterior }\end{array}$ \\
\hline$V$ & Riqueza total \\
\hline$V_{c, t}$ & Riqueza financeira dos Capitalistas \\
\hline$W_{h, t}$ & Salário dos trabalhadores mais qualificados \\
\hline$W_{l, t}$ & Salário dos trabalhadores menos qualificados \\
\hline$Y_{t}$ & Produto \\
\hline$Y_{t}^{*}$ & Produto de Plena Capacidade \\
\hline$Y_{D c, t}$ & Renda disponível dos capitalistas \\
\hline$Y_{D h, t}$ & Renda disponível dos trabalhadores mais qualificados \\
\hline$Y_{D c, t}$ & Renda disponível dos trabalhadores menos qualificados \\
\hline$Y_{W, t}$ & Renda da economia distribuída em salários \\
\hline$Y_{\pi, t}$ & Renda da economia distribuída em lucros \\
\hline$Y_{f i, t}$ & Parcela do produto associada à renda financeira \\
\hline$Y_{i, t}$ & Parcela do produto induzida pela renda \\
\hline$Y_{s, t}$ & Parcela do produto associada à riqueza \\
\hline$Y_{w p, t}$ & $\begin{array}{l}\text { Parcela do Produto associada à distribuição funcional da renda e à } \\
\text { distribuição de salários }\end{array}$ \\
\hline$\beta_{c, t}$ & Propensão a consumir sobre a renda disponível dos capitalistas \\
\hline
\end{tabular}




\begin{tabular}{|c|c|}
\hline$\beta_{h, t}$ & $\begin{array}{l}\text { Propensão a consumir sobre a renda disponível dos trabalhadores mais } \\
\text { qualificados }\end{array}$ \\
\hline$\gamma_{0, t}$ & $\begin{array}{l}\text { Parâmetro que reflete o animal spirits das firmas ou expectativa do } \\
\text { crescimento das vendas no tempo t }\end{array}$ \\
\hline$\gamma_{1, t}$ & Efeito da taxa de juros na taxa de acumulação no tempo t \\
\hline$\gamma_{2, t}$ & Efeito da utilização na taxa de acumulação \\
\hline$\theta_{c, t}$ & Propensão a consumir sobre a riqueza financeira dos capitalistas \\
\hline$\theta_{h, t}$ & $\begin{array}{l}\text { Propensão a consumir sobre a riqueza financeira dos trabalhadores mais } \\
\text { qualificados }\end{array}$ \\
\hline$\lambda_{0, c, t}$ & Parâmetro exógeno na alocação de portfólio dos capitalistas \\
\hline$\lambda_{1, c, t}$ & Parâmetro da taxa de juros na alocação de portfólio dos capitalistas \\
\hline$\lambda_{2, c, t}$ & Parâmetro da renda disponível na alocação de portfólio dos capitalistas \\
\hline$\lambda_{0, h, t}$ & $\begin{array}{l}\text { Parâmetro exógeno na alocação de portfólio dos trabalhadores mais } \\
\text { qualificados }\end{array}$ \\
\hline$\lambda_{1, h, t}$ & $\begin{array}{l}\text { Parâmetro da taxa de juros na alocação de portfólio dos trabalhadores } \\
\text { mais qualificados }\end{array}$ \\
\hline$\lambda_{2, h, t}$ & $\begin{array}{l}\text { Parâmetro da renda disponível na alocação de portfólio dos trabalha- } \\
\text { dores mais qualificados }\end{array}$ \\
\hline$\xi$ & Taxa de depreciação do estoque de capital \\
\hline$\sigma_{t}$ & Taxa de lucros \\
\hline$\tau_{B, t}$ & Alíquota de imposto sobre a renda financeira \\
\hline$\tau_{V, t}$ & Alíquota de imposto sobre a riqueza financeira \\
\hline$\tau_{W, t}$ & Alíquota de imposto sobre a renda dos salarial \\
\hline$\tau_{\pi, t}$ & Alíquota de imposto sobre a renda dos lucros \\
\hline$\varphi_{V, t}$ & $\begin{array}{l}\text { Parcela da riqueza financeira pertencente aos trabalhadores mais qua- } \\
\text { lificados ou distribuição de riqueza }\end{array}$ \\
\hline$\psi_{B, t}$ & $\begin{array}{l}\text { Parcela dos títulos públicos detida pelos trabalhadores mais qualifica- } \\
\text { dos }\end{array}$ \\
\hline$L, t$ & Parcela da renda dos trabalhadores na repartição líquida da renda \\
\hline
\end{tabular}


$\psi_{L, t} \quad$ Parcela dos salários dos trabalhadores menos qualificados na renda distribuída em salários ou distribuição salarial

$\psi_{W, t} \quad$ Parcela de salários na renda ou distribuição funcional da renda

$\omega_{t} \quad$ Meta de déficit primário em proporção do produto 


\section{Introdução}

A despeito da variável riqueza ter sido relevante na literatura econômica desde o início, a distribuição de riqueza foi frequentemente marginalizada. Entretanto, a publicação de $O$ Capital no Século XXI de Thomas Piketty mostrou como a concentração de riqueza torna-se cada vez mais central na atividade econômica.

De acordo com Piketty e Zucman (2015), a concentração de riqueza passou a crescer em boa parte dos países desenvolvidos a partir dos anos 80. Na França, ainda que o valor, em 2010, ainda estivesse distante do seu auge histórico ${ }^{1}$, o primeiro percentil da renda possuía aproximadamente $25 \%$ de toda a riqueza, enquanto que os $10 \%$ mais ricos possuíam mais de $60 \%$ da riqueza. Esse valor mostra-se bastante elevado, principalmente ao se comparar com a desigualdade de renda, pois esse mesmo decil se apropriava de 'apenas' 30\% da renda do trabalho. Assim como na França, no Reino Unido também vem acontecendo uma retomada da concentração de riqueza a níveis elevados. A igualdade na distribuição de riqueza começou a ter um sensível aumento após a primeira grande guerra, caindo de mais de $90 \%$ do primeiro decil no início do século para valores próximos de $60 \%$ nos anos 70. Todavia, a concentração voltou a subir nos anos 80, chegando ao patamar de $80 \%$. Assim, é cada vez mais difícil ignorar a questão da distribuição da riqueza, principalmente porque o valor da razão entre a riqueza e a renda nacional é crescente.

Piketty (2014) argumenta que essa mudança ocorreu devido a transformações na tributação e no crescimento do setor financeiro na economia, introduzidas no inicio da década de 80, que elevaram os rendimentos do capital (r). Uma vez que a taxa de remuneração dos estoques se tornou superior ao crescimento econômico $(\mathrm{g})$, os detentores destes passaram a ter uma renda maior que aqueles que apenas recebem renda do trabalho. Garbinti, Goupille-Lebret e Piketty (2017) estimam que o retorno médio de diferentes tipos de riqueza do decil mais rico da população francesa é de aproximadamente $6 \%$ ao ano, bem superior, portanto, ao crescimento dos salários. Esta situação leva a um processo de retroalimentação de elevação da concentração de renda (Piketty et al. (2017)) e de riqueza.

Destaca-se ainda a heterogeneidade entre os diversos tipos de riqueza. Garbinti, Goupille-Lebret e Piketty (2017) mostram que a proporção dos ativos financeiros e depósitos dos franceses é superior a $40 \%$ do agregado de sua riqueza, pelo menos o dobro do que era há 40 anos. A riqueza imobiliária é quase metade da total, $70 \%$ a mais do que fora no início dos anos 70. A relevância da riqueza financeira é ainda mais evidente ao se

1 Nos países apresentados, o auge da concentração de riqueza ocorreu na transição do século XIX para o século XX. 
aprofundar no 0,1\% mais rico da população francesa. A riqueza destes é primordialmente concentrada em ativos financeiros, ultrapassando $80 \%$ da sua riqueza total. Por outro lado, entre o quarto e o nono decil de renda da população, a riqueza imobiliária é superior a $60 \%$ da riqueza.

No Brasil, a riqueza financeira também é altamente concentrada. De acordo com dados da Anbima, em 2015, pouco mais de cem mil pessoas tinham riqueza per capita de aproximadamente 6 milhões de reais e cinco milhões de pessoas detinham em média 113 mil de reais em riqueza financeira. Já os outros sessenta e seis milhões de clientes possuíam em média pouco mais de 12 mil reais.

A partir desta perspectiva, a concentração de riqueza torna-se essencial para compreender como a economia brasileira se comportou nos últimos quinze anos. Ela permite modificar, por exemplo, um dos temas mais discutidos desse período: a redução da desigualdade de renda. Ao utilizar os dados da PNAD, o índice de Gini sobre a renda total indica uma queda do patamar de 0,57 em 2003 para 0,52 em 2014.

Contudo, o cálculo do índice de Gini que computa a renda sobre a riqueza mais detalhadamente tem um resultado diferente. Medeiros et al. (2015), ao utilizarem os dados da Declaração do Imposto sobre a Renda de Pessoa Física (DIRFP), que são mais completos que a PNAD para o rendimento dos mais ricos, redefinem os coeficientes de Gini no período 2006-2012. Esse índice se eleva nos três primeiros anos e em seguida tem uma leve queda nos três últimos, mantendo-se estável no período.

Medeiros e Castro (2016) explicam esse fenômeno a partir da concentração de riqueza. Por mais que tenha ocorrido uma maior distribuição nos salários, como os dados da PNAD indicam, a renda proveniente dos estoques se concentrou. No início do período, o decíl mais rico da população se apropriava aproximadamente de $20 \%$ deste tipo de renda ${ }^{2}$. Em 2012, este decíl passou a receber $30 \%$ dos rendimentos do capital, indicando uma piora nos índices de distribuição dos rendimentos sobre a riqueza. Esta questão torna-se ainda mais relevante devido à falta de políticas para a desconcentração na carga tributária brasileira( IPEA (2011), Salvador (2017) e Silveira et al. (2013)).

No caso estadunidense, ainda que houvesse políticas públicas para elevar a renda dos mais pobres ou tributar a renda dos mais ricos, o efeito na queda da desigualdade de renda seria pequeno, como destacam Taylor et al. (2014), Taylor, Omer e Rezai (2015) e Piketty et al. (2017). Isso ocorreria porque quatro quintos da renda do $1 \%$ mais rico tem origem em propriedades ou dividendos. Para os autores, apenas reduzindo a concentração de riqueza seria possível diminuir a desigualdade de renda estadunidense.

Nos estudos de economia que trataram a distribuição de riqueza por perspectiva

2 A renda proveniente da riqueza neste trabalho são os lucros, dividendos, rendas de empresas, ganhos e realizações de capital, aplicação financeira e renda variável, heranças e doações. Os aluguéis, por problemas metodológicos, não são computados nesse cálculo. 
neoclássica, destacam-se os trabalhos de Banerjee e Newman (1991), Galor e Zeira (1989) e Aghion e Bolton (1997). Estes, no arcabouço teórico do capital humano, investigaram como a riqueza afeta a tomada de decisão da escolaridade, e por isso a acumulação neste tipo de estoque. Mesmo em países ricos, se a riqueza fosse desigualmente distribuída, poucos decidiriam se escolarizar, o que reduziria o crescimento econômico. Assim, a maior igualdade na distribuição de riqueza seria essencial para potencializar a acumulação de capital.

Pela perspectiva pós-Keynesiana, a questão foi tratada tangencialmente nas teorias de distribuição e crescimento por Kaldor (1955) e Pasinetti (1962). Contudo, o foco dado pela literatura subsequente foi, principalmente, na distribuição da renda e na taxa de lucros. Dutt (1990) modificou a interpretação original, dando ao Teorema de Pasinetti uma explicação a partir da distribuição de riqueza. Deste trabalho, seguiram-se outros, como Dutt (2016), Palley (2012), Palley (2013) e Palley (2016). Além disso, as teorias de Kaldor e Pasinetti, ao supor utilização de capacidade exógena no longo prazo, acabavam por pouco estudar como estas distribuições se relacionavam com a demanda na economia. Assim, dentro do arcabouço pós-Keynesiano, destacam-se os modelos Kaleckianos, que inicialmente se concentraram nos efeitos de mudanças na distribuição funcional da renda (salários e lucros) sobre a demanda agregada.

Dessa forma, o objetivo desta dissertação de mestrado é abordar a questão de como a distribuição de riqueza financeira tem causas e correlações com a distribuição de renda e com a utilização de capacidade, dentro do arcabouço Kaleckiano, com uma modelagem Stock-Flow-Consistent, contribuindo para o debate desenvolvido inicialmente por Pasinetti (1962) e posteriormente por Dutt (1990), Dutt (2016), e Palley (2012), Palley (2014), Palley (2016).

O modelo aqui desenvolvido terá três classes, sendo duas de trabalhadores e uma de capitalistas. A divisão dos trabalhadores entre menos qualificados e mais qualificados permite tirar algumas conclusões acerca da distribuição entre os salários (Carvalho e Rezai (2015), Palley (2015)). Além disso, tanto os trabalhadores mais qualificados como os capitalistas, ao pouparem parte de sua renda, alocam a sua poupança em títulos públicos e moeda. Os primeiros geram rendimentos a cada período, permitindo que a riqueza gere novos fluxos. O governo tributa salários, lucros, renda financeira e riqueza financeira. Com esses impostos e emitindo dívida o governo realiza os seus gastos. Por fim, as firmas investem a depender da demanda da economia e da massa de lucros.

O resto desta dissertação está organizado da seguinte forma: O primeiro capítulo apresenta o arcabouço teórico que embasa o modelo a ser desenvolvido. A literatura Kaleckiana seminal é mostrada, desenvolvendo os modelos iniciais que buscam compreender como a distribuição entre salários e lucros afeta a demanda e a taxa de lucros, assim como algumas extensões. Em seguida, é explicitado como a variável riqueza permeia a 
atividade econômica, tanto do ponto de vista teórico como empírico. Posteriormente, são desenvolvidos os modelos de Kaldor (1955) e Pasinetti (1962) e seus desdobramentos. Por fim, são exibidos modelos que seguem esta literatura, mas que colocam a distribuição de riqueza como ponto central.

No segundo capítulo, o modelo é apresentado, indicando as diversas fontes de renda das classes, assim como os trabalhadores mais qualificados e capitalistas alocam a sua riqueza financeira. Além disso, a solução de curto prazo é encontrada e, assim, é possível entender como mudanças nas variáveis exógenas alteram a demanda agregada.

No terceiro capítulo, as variáveis de estoque que, no curto prazo, eram pré determinadas podem variar até chegar em um equilíbrio de longo prazo. Assim, as equações dinâmicas do estoque de capital, das riquezas financeiras e dos títulos públicos detidos pelas classes são desenvolvidas. Com tais dinâmicas, e supondo alguns valores iniciais, são realizadas simulações que buscam entender como mudanças nos comportamentos das classes, na distribuição entre salários e lucros, na distribuição salarial, e em políticas econômicas alteram a distribuição de riqueza, a repartição da renda e a utilização de capacidade no longo prazo. 


\section{Literatura neo-Kaleckiana}

\subsection{Literatura Kaleckiana}

O ponto inicial da teoria de distribuição de Kalecki (1954) é o modelo de definição de preços a partir do mark-up (Trigg (1994)). Nesse modelo, o preço médio é calculado por uma regra de mark-up, $\mu$, aplicada sobre o custo unitário da produção. Desta forma, a participação de salários na economia é determinada pela razão entre custo de salários e o custo dos materiais, assim como pelo grau de monopólio da economia e de sindicalização dos trabalhadores, os dois primeiros fatores afetando o custo unitário médio e os dois últimos determinantes do mark-up (Kalecki (1943)). Assim, se o mark-up se eleva, os capitalistas detêm uma parcela maior do produto nacional.

Como Kalecki acreditava que a distribuição de renda era um dos caminhos para o pleno emprego (Kalecki (1944)), esta variável torna-se essencial para entender a dinâmica da atividade econômica. Dessa forma, destaca-se a diferença dos modelos neo-Keynesianos para os Kaleckianos. Nos primeiros, inspirados por Keynes (1936), as firmas operam em competição perfeita e a utilização de capacidade no longo prazo opera a plena capacidade ou é fixa (Lavoie (1995)). Assim, em uma economia de um único setor, no longo prazo, há uma relação necessariamente inversa entre salário real e acumulação, uma vez que a distribuição de renda reduz a taxa de lucros, e portanto, o investimento.

A teoria de crescimento Kaleckiana seguiu os passos de Kalecki, mas estendeu a teoria para o longo prazo (Dutt (2012)). Como destaca Amadeo (1987), os primeiros modelos dessa abordagem foram desenvolvidos independentemente por Rowthorn (1981) e Dutt (1984), ainda que os principais resultados tenham sido encontrados anteriormente por Monte (1975). Dutt estava preocupado com a desaceleração da economia industrial indiana, iniciada na década de 60, e acreditava que a "desigualdade da distribuição de renda resultava numa limitada demanda pelos bens industriais, reduzindo os incentivos para investir, e assim reduzindo o crescimento"(Dutt (1984)[p.25]).

Lavoie (2014) argumenta que a literatura Kaleckiana possui quatro aspectos: i) a função investimento deve ser uma função da utilização de capacidade, ainda que também possa ser de outras variáveis ${ }^{1}$. ii) os preços são definidos por forças convencionais como uma margem sobre os custos. iii) a propensão a consumir dos salários, $\beta_{w}$, deve ser inferior à propensão a consumir dos lucros, $\beta_{c}$. iv) a utilização de capacidade da economia é

1 De acordo com Trigg (1994), há uma certa confusão na literatura se a inclusão da utilização de capacidade na função investimento pode ser atribuída a Kalecki. O objetivo desse trabalho não é entrar nesse debate, uma vez que não é possível determinar qual seria a função de investimento de Kalecki, pois o autor não chegou a uma conclusão definitiva. 
geralmente menor do que $1^{2,3}$, ou seja, há capacidade ociosa, e o fator trabalho não é uma restrição.

A versão do modelo desenvolvida por Rowthorn (1981) e Dutt (1984) supõe uma função investimento Kalecki-Steindl, isto é, que o crescimento do estoque de capital é função do 'espírito animal' dos empresários, representada aqui por $\gamma_{0}^{4}$, da taxa de lucros, $\sigma$, e da utilização de capacidade, $u$, e que a propensão a consumir dos trabalhadores sobre os salários é zero. Assim:

$$
\begin{gathered}
g^{i}=\frac{I}{K}=\gamma_{0}+\gamma_{1} \sigma+\gamma_{2} u \\
g^{s}=\frac{S}{K}=\left(1-\beta_{c}\right) \sigma
\end{gathered}
$$

A taxa de lucros na função investimento é justificada a partir da perspectiva de que quanto maiores os lucros esperados, mais as firmas buscam investir para conseguir tal renda. O mesmo fenômeno explica a inclusão da utilização de capacidade. Se ela está acima da desejada, as firmas buscam elevar o estoque de capital para aumentar a capacidade de produção. Repare que o fato de $\sigma=\left(1-\psi_{W}\right) u / v$, faz com que a utilização apareça duas vezes na função investimento ${ }^{5}$.

Dessa forma, ao supor que há equilíbrio no mercado de bens, isto é, $I=S$ :

$$
\begin{gathered}
u^{*}=\frac{\gamma_{0} v}{\left(1-\beta_{c}-\gamma_{1}\right)\left(1-\psi_{W}\right)-v \gamma_{2}} \\
\frac{\partial u^{*}}{\partial \beta_{c}}=\frac{\left(1-\psi_{W}\right) \gamma_{0} v}{\Delta_{1}^{2}}>0 \\
\frac{\partial r^{*}}{\partial \psi_{W}}=\frac{\gamma_{0} \gamma_{1} v}{\Delta_{1}^{2}}>0
\end{gathered}
$$

Tal que $\Delta_{1}$ é o numerador de (1.3).

Assim, supondo que vale a estabilidade keynesiana, isto é, $\frac{\partial g^{s}}{\partial u}>\frac{\partial g^{i}}{\partial u}{ }^{6}$, um aumento na propensão a consumir dos capitalistas eleva a utilização de capacidade, exatamente

2 Esta hipótese é atribuída a Steindl (1952). Para o autor, as firmas desejam ter um excesso de capacidade para conseguir absorver flutuações de demanda sem perder parcela no mercado, dada a indivisibilidade de plantas e as barreiras à entrada.

$3 u=\frac{Y}{Y^{*}}=\frac{Y}{K} \frac{K}{Y^{*}}$, em que u é a utilização de capacidade, Y é o produto corrente, $Y^{*}$ é a o produto de plena capacidade, e K é o estoque de capital.

4 Aqui as variáveis são adaptadas para melhor serem comparadas com aquelas que são utilizadas nos capítulos 2 e 3

5 Tal que $\psi_{W}$ é a parcela de salários na renda e $v$ é a relação capital-produto de plena capacidade.

6 A estabilidade Keynesiana supõe que aumentos na utilização de capacidade elevam mais a poupança do que o investimento. Como Lavoie (2014) diz, se o contrário ocorrer, os empresários vão superestimar a utilização de equilíbrio. Assim, eles são induzidos a aumentar ainda mais o investimento, fazendo 
o oposto dos modelos mainstream. Nos modelos neoclássicos é a poupança que gera o investimento. Como o aumento no consumo das famílias reduz a poupança, o investimento cai. Nos modelos Kaleckianos, é a demanda efetiva que determina a produção da economia. Assim, o aumento do consumo eleva a renda da economia e por isso o investimento ${ }^{7}$. Tal situação, por ser uma conclusão diferente do esperado nos modelos mainstream, é denominada de paradoxo da poupança. .

Além disso, o aumento da parcela de salários na renda eleva a utilização, verificandose o paradoxo dos custos, pois a taxa de lucros também irá aumentar. De acordo com Lavoie (2014), esse último é o resultado mais intrigante dos modelos Kaleckianos, pois, do ponto de vista da firma individual, o aumento dos salários reduz os seus lucros. Contudo, maiores salários aumentam o consumo, elevando a utilização, que por sua vez amplia o investimento e, consequentemente a taxa de lucros agregada.

Há, contudo, dois caminhos na literatura Kaleckiana que questionam o fato de um aumento na parcela de salários na renda necessariamente elevar a utilização e a taxa de lucros: Amadeo (1987) e Bhaduri e Marglin (1990). O primeiro, ao introduzir uma propensão a consumir sobre os salários menor do que a unidade, altera a função poupança. Dessa forma:

$$
\begin{gathered}
g^{s}=\frac{S}{K}=\left(1-\beta_{c}\right)\left(1-\psi_{W}\right) u / v+\left(1-\beta_{w}\right) \psi_{W} u / v \\
u^{*}=\frac{\gamma_{0} v}{\left(\beta_{w}-\beta_{c}-\gamma_{1}\right)\left(1-\psi_{W}\right)-v \gamma_{2}} \\
\frac{\partial u^{*}}{\partial \beta_{i}}>0 \\
\frac{\partial u_{W}^{*}}{\partial \psi_{W}}=\frac{\gamma_{0} v\left(\beta_{w}-\beta_{c}-\gamma_{1}\right)}{\Delta_{2}^{2}} \lessgtr 0 \\
\frac{\partial r^{*}}{\partial \psi_{W}}=\frac{\gamma_{0}\left(\left(1-\beta_{w}\right)-v \gamma_{2}\right)}{\Delta_{2}^{2}} \lessgtr 0
\end{gathered}
$$

Em que $\Delta_{1}$ é o numerador de (1.5).

Assim, a inclusão de uma propensão a poupar positiva sobre os salários não altera a validade do paradoxo da poupança. Porém, o aumento na parcela de salários na renda só aumenta a utilização se $\left(\beta_{h}-\beta_{c}-\gamma_{1}\right)>0$, isto é, se a elevação no consumo dos

com que o excesso de demanda permaneça. Este excesso aumentará ainda mais a capacidade, gerando um efeito retroalimentativo.

7 A poupança, nesses modelos, é um resíduo (Lerner, 1951). 
trabalhadores for maior do que a queda no consumo dos capitalistas e no investimento. Além disso, o paradoxo dos custos se verifica quando $\beta_{h}>v \gamma_{u}$.

Para Bhaduri e Marglin (1990), a função investimento do modelo de Rowthorn (1981) e Dutt (1984) possui um problema. É possível que a taxa de lucros permaneça constante, ainda que a parcela dos lucros na renda caia, uma vez que um aumento proporcional da utilização a compensaria. Para os autores, tal redução na parcela dos lucros deveria ter um impacto no investimento das firmas. Em seu modelo há uma mudança na função investimento, substituindo a taxa de lucros pela parcela de lucros na renda, assim:

$$
\begin{gathered}
g^{i}=\frac{I}{K}=\gamma_{0}+\gamma_{1}\left(1-\psi_{W}\right)+\gamma_{2} u \\
u^{*}=\frac{\left(\gamma_{0}+\gamma_{1}\left(1-\psi_{W}\right)\right) v}{\left(1-\beta_{c}\right)\left(1-\psi_{W}\right)-v \gamma_{2}} \\
\frac{\partial u^{*}}{\partial \beta_{c}}>0 \\
\frac{\partial u^{*}}{\partial \psi_{W}}=\frac{v\left(\gamma_{1} \gamma_{2} v+\gamma_{0}\left(1-\beta_{c}\right)\right)}{\Delta_{3}^{2}} \lessgtr 0 \\
\frac{\partial r^{*}}{\partial \psi_{W}}=\frac{\gamma_{0} \gamma_{2} v-\left(\left(1-\beta_{h}\right)\left(1-\psi_{W}\right)-2 \gamma_{2} v\right)\left(1-\psi_{W}\right) \gamma_{1}}{\Delta_{3}^{2}} \lessgtr 0
\end{gathered}
$$

Tal que $\Delta_{3}$ é o denominador de (1.7)

Assim como na inclusão da propensão a poupar dos salários, a mudança na função investimento não deixa de verificar o paradoxo da poupança. Contudo, como $\gamma_{0}$ deixa de necessariamente ser positivo ${ }^{8}$, o efeito na utilização de capacidade torna-se ambíguo. Além disso, o paradoxo dos custos não necessariamente vale, como é possível observar na derivada da taxa de lucros com relação à proporção de salários na renda.

Dessa forma pode-se concluir que o aumento da parcela dos salários na renda pode ter efeito ambíguo na utilização de capacidade. Se a utilização se elevar denomina-se que a economia opera em um regime wage-led, ou seja, que o aumento da parcela dos salários aumenta a demanda. Tal situação é observada inequivocamente no primeiro modelo apresentado, enquanto que, é apenas uma possibilidade na inclusão de uma poupança de salários positiva e/ou na inclusão da parcela dos lucros na função investimento. Caso a utilização diminua após o aumento da parcela de salários, denomina-se o regime de demanda como profit-led.

8 Repare que por (1.3), supondo a estabilidade keynesiana, $\gamma_{0}$ deve ser positivo. Caso contrário a utilização de capacidade seria negativa, o que não tem sentido econômico. Já em $(1.7)$, é $\left(\gamma_{0}+\gamma_{1}(1-\right.$ $\left.\psi_{W}\right)$ ) que deve ser positivo. Conclui-se que $\gamma_{0}$ pode ser negativo. 


\subsubsection{Desenvolvimento da Literatura}

A partir desse paradigma a literatura Kaleckiana desenvolveu-se teoricamente buscando abarcar diversas extensões aos modelos canônicos e pós-Kaleckianos. Entre elas destacam-se o efeito da inclusão da economia aberta (Blecker (2011), Hein e Vogel (2008)), distribuição pessoal da renda (Dutt (1992),Lavoie (1996), Palley (2015), Tavani e Vasudevan (2014) Carvalho e Rezai (2015)), e endividamento das famílias (Dutt (2011a), Barba e Pivetti (2009) e Palley et al. (2010)) além de uma incipiente extensão para incluir a distribuição de riqueza como em Palley (2012), Palley (2016) e Dutt (2016).

\subsubsection{Distribuição Pessoal da Renda}

Em Teoria da Dinâmica Econômica, Kalecki (1954), seguindo os 'esquemas de reprodução' marxistas, divide a economia em três departamentos: o Departamento I, que produz bens de capital, o Departamento II, que produz bens de consumo para os capitalistas e o Departamento III, que produz os bens de consumo para os trabalhadores. Ainda que o autor, na época, não tivesse separado os trabalhadores que estavam alocados em diferentes departamentos, é possível supor que o salário de cada um deles seria diferente a depender da produtividade do departamento.

Dutt (1992) ainda que não trate explicitamente das diferenças salariais, aborda a coexistência entre dois setores de produtividades diferentes. Para o autor, em uma economia com restrição de demanda e com determinação de preços a partir de um markup sobre os custos diretos, o aumento do crescimento de um setor de menor produtividade aumenta a acumulação do setor de maior produtividade. Isso ocorre porque o aumento do emprego do setor menos produtivo eleva a demanda do setor mais produtivo, acarretando em um aumento deste setor também, uma vez que este é puxado pela demanda. Esse resultado vai contra o que é observado nos modelos neoclássicos e neo-marxianos.

Lavoie (1996) toma um outro caminho ao modificar a regra de determinação de preços. De acordo com o autor, os preços são determinados a partir de uma meta de retorno da taxa de lucros. Dessa forma, trabalhadores improdutivos, como uma classe gerencial, passam a ser incluídos na determinação de preços. Assim, o aumento da parcela de trabalhadores improdutivos ou de salários dos mesmos necessariamente aumenta os preços. A depender do tamanho da elevação desses preços, haverá uma queda na parcela de salários na renda, reduzindo a utilização de capacidade.

Este efeito nos preços varia a depender de em qual estágio está a economia. Se as firmas estiverem operando em uma utilização de capacidade abaixo da desejada, o aumento nos preços não compensa totalmente a elevação nos custos unitários. Assim, há um efeito positivo na utilização de capacidade, na taxa de lucros e no crescimento, pois o aumento do consumo real dos trabalhadores improdutivos mais do que compensa a queda do consumo 
dos trabalhadores produtivos. Por outro lado, se a utilização de capacidade estiver superior à desejada, um aumento no custo dos trabalhadores improdutivos é totalmente repassado aos consumidores. Dessa forma, o efeito na demanda é negativo, uma vez que o consumo real dos trabalhadores improdutivos permanece o mesmo, enquanto que o dos trabalhares produtivos cai.

Segundo Lavoie (2014), isso evidencia problemas em estudos que definem uma economia como wage-led ou profit-led, ao utilizar apenas os custos diretos na formação de preços. Suponha, por exemplo, que há um aumento na utilização de capacidade, ao mesmo tempo em que a parcela de salários na renda diminui. Essa economia seria caracterizaria como profit-led. Contudo, a premissa anterior pode acontecer concomitantemente com um aumento nos salários dos trabalhadores improdutivos, significando um aumento do salário real médio. Dessa forma, a economia é, na prática, wage-led, a despeito da conclusão anterior.

Tavani e Vasudevan (2014) constroem um modelo com três classes, com o objetivo de entender como a desigualdade salarial afeta a utilização de capacidade. Além dos capitalistas, os assalariados são divididos entre trabalhadores e gerentes, que recebem maiores salários, e por conseguinte, poupam parte da renda. Como os gerentes têm como função supervisionar os trabalhadores, uma maior remuneração dos gerentes, melhora a produtividade dos trabalhadores, gerando um excedente ainda maior para os capitalistas. Por causa disso, tanto em economias wage-led como em economias profit-led, uma maior desigualdade salarial aumenta a utilização de capacidade, caracterizando a economia como inequality-led. Dessa forma, um aumento da parcela dos salários em prol dos trabalhadores, reduz a demanda agregada, a despeito de reduzir a desigualdade de renda.

Palley (2015) também desenvolve um modelo que possui uma terceira classe, os gerentes, além dos capitalistas e trabalhadores. De acordo com o autor, uma menor proporção de gerentes pode alterar o regime de demanda da economia. Considerando que os trabalhadores têm uma propensão marginal a consumir mais elevada que os gerentes, um aumento da proporção ou da renda dos primeiros relativamente aos segundos eleva a propensão marginal a consumir média dos assalariados. Neste caso, mudanças na proporção de salários na renda passam a afetar mais o consumo dos trabalhadores do que uma economia em que os gerentes têm uma proporção maior da renda dos salários. Assim, uma economia que antes era profit-led, pois o efeito no consumo era insuficiente para compensar o efeito no investimento, pode passar a ser wage-led.

Por fim, Carvalho e Rezai (2015), diferentemente dos anteriores, não introduzem uma terceira classe. Os autores supõem que os trabalhadores são heterogêneos, e assim têm propensões a poupar crescentes na renda ${ }^{9}$. Esse fato estilizado traz duas consequências: i) uma mudança na distribuição pessoal da renda em prol dos trabalhadores mais bem

$9 \quad$ Esta suposição é verificada empiricamente pelos autores 
remunerados reduz a demanda agregada, uma vez que reduz o consumo. ii) De acordo com modelo de Amadeo(1987) que foi apresentado anteriormente, há uma queda na propensão média a consumir dos trabalhadores, afetando o resultado em ser wage-led ou profit-led.

Assim como Palley (2015), de uma maneira geral, uma maior igualdade salarial faz com que uma economia passe a ser mais wage-led. Contudo, se a economia é fortemente profit-led, significa que o investimento responde muito à taxa de lucros e a diferença entre as propensões a poupar é pequena. Dessa maneira, uma mudança na distribuição pessoal da renda em prol dos trabalhadores mais pobres deixa a economia ainda mais profit-led. Com este modelo, Carvalho e Rezai (2015) realizam um exercício empírico para tentar entender qual o efeito da distribuição pessoal da renda sobre o resultado profit-led da economia estadunidense em Barbosa-Filho e Taylor (2006). Para os autores, a crescente desigualdade salarial estadunidense intensificou o fraco caráter profit-led.

\subsection{Riqueza na Literatura Econômica}

Como Hunt (1981) aborda, Smith (1776) buscava mostrar as interconexões entre as classes sociais, os variados setores da produção assim como a distribuição de renda e riqueza e o processo de crescimento econômico. Ricardo (1821), ao seguir a distribuição de classes de Smith entre trabalhadores, capitalistas e rentistas também via na riqueza algo essencial para compreender o crescimento econômico. Para o autor, os interesses dos rentistas, isto é, daqueles que tinham renda derivada da posse das terras mais produtivas, iriam contra o interesse de toda a sociedade, pois o conflito dessa classe com os capitalistas reduziria a taxa de lucro, e por isso, a riqueza da sociedade. Marx (2001) entendia que a economia capitalista era dividida entre trabalhadores, que geravam valor-trabalho, e capitalistas, que detinham toda a posse dos meios de produção. E assim, na sua famosa formulação, o objetivo do capitalista era pegar capital $D$, e gerar mais capital $D^{\prime}$, por meio da criação de valor a partir do trabalho. Tal forma de acumulação e concentração de riqueza, entretanto, acabaria gerando uma queda na taxa de lucros e, paradoxalmente, uma redução no processo de acumulação da economia.

Ando e Modigliani (1963), ao elaborarem o modelo de ciclo de vida, consideram que as famílias acumulam e depois consomem parte de sua riqueza, de modo a manter o padrão de consumo relativamente estável durante a vida. Assim, aumentos persistentes inesperados na riqueza levariam as famílias a elevar o consumo, uma vez que a poupança necessária seria menor. Por um ponto de vista institucionalista, há os que entendem que o consumo sobre a riqueza deriva do consumo conspícuo Veblen (1988). Para Duesenberry (1949), como o consumo é interdependente ${ }^{10}$, as classes buscam consumir não apenas

10 O consumo interdependente supõe que que os consumidores observam e copiam uns aos outros. Como destaca Lavoie (2014), as preferências não são inatas, elas são adquiridas com a experiência e pela imitação. 
aquilo que seria compatível com a sua renda, mas de acordo com o que seus vizinhos e classes superiores, de modo a emular um estilo de vida ostensivo. Destarte, as famílias utilizariam parte dessa riqueza como forma de se aproximar deste padrão de consumo que traz prestigio na sociedade.

Dessa forma, nessa seção serão abordados os modelos que colocam a riqueza como parte essencial. Inicialmente são explicitados alguns modelos que buscam tratar a riqueza sem a preocupação a distribuição em si. Em seguida, os estudos empíricos sobre a riqueza na função consumo são apresentados. Posteriormente o Teorema de Pasinetti (1962) é mostrado assim como as críticas e limitações, expondo alguns trabalhos que se seguiram nessa literatura. Em seguida, são apresentados os modelos em que a distribuição da riqueza tem papel preponderante em uma perspectiva Kaleckiana.

\subsubsection{Como a riqueza pode afetar a atividade econômica?}

Galor e Zeira (1989) utilizam um modelo de gerações sobrepostas em que os indivíduos da mesma família possuem altruísmo, preocupando-se com a utilidade dos seus descendentes. Considerando que o investimento ocorre apenas em capital humano, os autores buscam compreender como a riqueza afeta o investimento por escolaridade dos indivíduos. Assim, de acordo com o valor do patrimônio herdado, o indivíduo decide qualificar-se para ter um salário superior. Portanto, dependendo da riqueza total do país e de sua distribuição, as economias poderão ser pobres ou ricas no longo prazo.

Dutt (2011a) constrói um modelo de duas classes, capitalistas e trabalhadores, de base Kaleckiana. Estes últimos consomem toda a sua renda e tomam emprestado dos bancos de forma a complementar o consumo. Dessa forma, a cada instante, os trabalhadores pagam juros sobre as dívidas tomadas nos períodos anteriores e fazem mais dívida. Além disso, os capitalistas, como donos dos bancos, recebem o pagamento dos juros feito pelos trabalhadores ${ }^{11}$. No curto prazo o aumento do endividamento impulsiona a demanda agregada ao elevar o consumo das famílias. No longo prazo, os pagamentos dos juros pelos tomadores aos emprestadores reduzem a demanda, pois diminuem a renda da classe que tem uma propensão a consumir maior.

O autor ainda aborda como essa introdução de riqueza pode afetar a estabilidade do sistema. Supondo que uma maior dívida significa que há uma maior fragilidade financeira, as firmas e os capitalistas podem entender um maior endividamento como um perigo para a sua saúde financeira, reduzindo o investimento e o consumo. Assim, o maior endividamento, no longo prazo, leva não apenas à transferência de renda entre classes

11 No modelo, Dutt considera que a economia funciona de modo overdraft (Hicks (1974)), isto é, os bancos são capazes de ofertar todo o crédito que as famílias demandarem, sem a necessidade de poupança prévia. Assim, o aumento da dívida dos trabalhadores não significa redução da renda dos capitalistas. 
com propensões a consumir diferentes, como à redução do investimento das firmas e da propensão a consumir dos capitalistas, diminuindo ainda mais a demanda.

O modelo desenvolvido por Bhaduri, Laski e Riese (2006), também Kaleckiano, não apenas inclui a possibilidade de endividamento como forma de elevar o consumo, como também introduz o efeito da riqueza diretamente no consumo e no investimento. $\mathrm{O}$ consumo é impactado por uma propensão marginal a consumir sobre a riqueza ${ }^{12}$ enquanto o investimento é uma função positiva da riqueza, pois esta reduz o risco de financiamento e torna o custo de investimento em capital menor comparado a aquisição no mercado de ações ${ }^{13}$. Por fim, a taxa de juros impacta não somente positivamente a poupança das famílias como negativamente a riqueza virtual e o investimento. É nesse sentido que o autor coloca riqueza como parte central do modelo. Por um lado ela tem efeitos diretos na demanda agregada via consumo e investimento. Por outro, a potencial elevação da taxa de juros, ao depreciar o valor da riqueza virtual, teria efeitos negativos ainda mais acentuados do que aquele que era observado em Dutt (2011a).

Já em Ryoo (2016), a inclusão da riqueza ocorre não apenas através do endividamento, mas também nos imóveis dos trabalhadores. Esta eleva a riqueza líquida dos trabalhadores, permitindo um maior colateral para a obtenção de empréstimos. Dessa forma, uma bolha imobiliária como a estadunidense, que durou dos anos 80 até a metade dos anos 2000, impulsionaria o consumo dos trabalhadores.

Com relação aos estudos empíricos, como destaca Paiella (2009), os modelos macroeconomicos de Ludvigson e Steindel (1999), Mehra (2001), Davis e Palumbo (2001) e Lettau e Ludvigson (2004) indicam que cada aumento de um dólar na riqueza levaram a um aumento entre 3 e 5 centavos no consumo das famílias. Além disso, Boone, Giorno e Richardson (1998) e Catte et al. (2004) obtém resultados parecidos, apenas ampliando esse intervalo, entre 1 centavo e 8 centavos a depender do país.

Altissimo et al. (2005) e Sousa (2009) buscam distinguir os efeitos entre a riqueza financeira e a riqueza a partir dos imóveis. O primeiro, ao fazer uma revisão dos estudos empíricos considera, que o efeito do consumo a partir da riqueza imobiliária é mais forte do que o efeito da riqueza financeira. Já o segundo, a partir de uma estimação dynamic ordinary least squares e GMM, encontra efeito oposto. Para este, o aumento da riqueza imobiliária em um euro aumenta o consumo em 0,1 centavo, enquanto que o mesmo aumento da riqueza financeira aumenta o consumo entre 5 e 7 centavos, a depender da origem desta riqueza. Por fim, cabe destacar que existe uma diferença das propensões a consumir sobre a riqueza entre os países. Segundo Slacalek (2006), os efeitos riqueza nos países anglo-saxões são superiores aos da zona do Euro.

12 A riqueza que Badhuri se refere neste artigo é a virtual, ou seja, aquela que é divisível e aparentemente líquida, diferenciando-se do estoque de capital físico.

13 Este último relaciona-se a Tobin (1969) 


\subsubsection{A Equação de Cambridge e seus desdobramentos}

Kaldor (1955) parte de um modelo neo-keynesiano, isto é, em que no longo prazo há pleno emprego ${ }^{14}$. Além disso, divide as famílias de acordo com a fonte da sua renda, aqueles que recebem os salários (W) e os que recebem lucros $(\mathrm{P})$ do seu estoque de capital. Por fim, ambas as categorias poupam parte de sua renda, isto é, $S_{w}=s_{w} W$ e $S_{p}=s_{p} P$. Assim,

$$
\begin{aligned}
& Y=W+P \\
& S=S_{w}+S_{c}
\end{aligned}
$$

Supondo que há equilíbrio no mercado de bens $(I=S)$, o autor conclui que:

$$
\begin{gathered}
\frac{P}{Y}=\frac{1}{s_{c}-s_{w}} \frac{I}{Y}-\frac{s_{w}}{s_{c}-s_{w}} \\
\frac{P}{K}=\frac{1}{s_{c}-s_{w}} \frac{I}{K}-\frac{s_{w}}{s_{c}-s_{w}} \frac{Y}{K}
\end{gathered}
$$

Dessa forma, a proporção de lucros na economia se daria por (1.10), enquanto a taxa de lucros é determinada por (1.11). Assim, supondo um crescimento exógeno, g, do estoque de capital, a distribuição entre salários e lucros é função das propensões a poupar das famílias. Repare ainda que se $s_{w}>\frac{I}{Y}$ a parcela de lucros na renda é zero (ou negativa) e se $s_{c}>\frac{I}{Y}$ os salários são nulos.

Contudo, como diz Pasinetti

"Há uma escorregada lógica, na teoria acima (...). Os autores negligenciaram o fato de, em qualquer sociedade, quando um indivíduo poupa parte de sua renda, ele deve poder possuir essa poupança, caso contrário, ele não iria poupar. Isso significa que o estoque de capital que existe nesse sistema deve ser possuído pelas pessoas (capitalistas ou trabalhadoras) que no passado fizeram as respectivas poupanças. E como a posse do capital autoriza ao seu dono uma taxa de juros, se os trabalhadores poupam (...) eles devem receber uma parcela dos lucros." (Pasinetti (1962)[p. 270][tradução própria]

14 Palley (2013) destaca que, enquanto que no modelo de Cambridge há plena capacidade e por isso a taxa de lucro é enfatizada, no modelo Kaleckiano a utilização de capacidade é variável, o que a torna central na dinâmica de crescimento e distribuição. Dessa forma, o modelo Kaleckiano constitui uma abordagem diferente, mas parecida, para o crescimento e distribuição. Assim, os resultados apresentados nessa seção também são válidos para a literatura Kaleckiana. 
Dessa forma, as equações (1.8), (1.10) e (1.11) devem ser modificadas

$$
\begin{gathered}
I=W+P_{c}+P_{w} \\
\frac{P_{c}}{Y}=\frac{1}{s_{c}-s_{w}} \frac{I}{Y}-\frac{s_{w}}{s_{c}-s_{w}} \\
\frac{P_{c}}{K}=\frac{1}{s_{c}-s_{w}} \frac{I}{K}-\frac{s_{w}}{s_{c}-s_{w}} \frac{Y}{K}
\end{gathered}
$$

Consequentemente, as expressões que Kaldor (1955) havia encontrado não se referiam à distribuição entre salários e lucros. Elas se relacionam apenas à distribuição dos lucros entre trabalhadores e capitalistas. Assim, considerando que a taxa de juros é igual à taxa de lucros, isto é, $r=\frac{P}{K}$ :

$$
\begin{aligned}
& \frac{P}{Y}=\frac{1}{s_{c}} \frac{I}{Y} \\
& \frac{P}{K}=\frac{1}{s_{c}} \frac{I}{K}
\end{aligned}
$$

Isso significa que, no longo prazo, a decisão de poupança dos trabalhadores, ainda que influencie a distribuição de renda entre trabalhadores e capitalistas por (1.13), não determina a distribuição funcional da renda, ou seja, entre salários e lucros, nem a taxa de lucros. Isso é conhecido como Teorema de Pasinetti. Cabe ainda destacar uma outra relação que Pasinetti (1962) coloca. De acordo com o autor, no longo prazo, a razão dos lucros que cada classe recebe é proporcional a poupança das mesmas, isto é:

$$
\frac{P_{w}}{S_{w}}=\frac{P_{c}}{S_{c}}
$$

Uma vez que os trabalhadores poupam parte da renda dos salários e dos lucros, isso significa que $S_{w}=s_{w}\left(W+P_{w}\right)$. Dessa forma:

$$
s_{w}\left(W+P_{w}\right)=s_{c} P_{w}
$$

Tal relação mostra que, quando os trabalhadores poupam, eles recebem uma renda a partir dos lucros, $P_{w}$, em que a sua poupança total seja exatamente igual àquela que que os capitalistas teriam poupado se tivessem recebido essa mesma renda. Além disso:

$$
\frac{P_{w}}{S_{w}}=\frac{P_{w}}{s_{w}\left(W+P_{w}\right)}
$$




$$
\frac{P_{c}}{S_{c}}=\frac{P_{c}}{S_{c} P_{c}}
$$

Como os salários, W, são determinados independentemente da propensão a poupar dos trabalhadores, para qualquer valor desta última, há infinitas soluções entre lucros (dos trabalhadores) e poupança a ponto de validar (1.19). Contudo, para (1.20), cada valor na propensão a poupar dos capitalistas tem apenas uma relação entre lucros (dos capitalistas) e poupança. Assim, é a relação dos capitalistas, (1.20), que determina a razão entre lucros e poupança para os trabalhadores.

Assim, a despeito dos trabalhadores poderem influenciar na proporção de lucros que irão receber, ao modificar a proporção que eles detém no estoque de capital $^{15}$, eles não têm o menor poder no valor total de lucros da economia, e portanto sobre o quanto irão receber. Apenas os capitalistas possuem capacidade de determinar o total de lucros.

Gupta (1976), ao considerar que a taxa de juros ${ }^{16}$ é diferente da taxa de lucros, mostra que a independência da taxa de lucros em relação à propensão a poupar dos trabalhadores não é mais válida. Isso ocorre porque a diferença entre a taxa de lucros e a taxa de juros passa a funcionar como a propensão a poupar dos capitalistas. Uma queda nessa diferença funciona como uma redistribuição de renda dos capitalistas para os trabalhadores, pois $s_{w}<s_{c}$, o que reduz a taxa de lucros.

Palley (1996), que inclui a possibilidade do endividamento dos trabalhadores, também invalida o Teorema de Pasinetti, pois o aumento desta classe reduz tanto a parcela dos lucros como a taxa de lucros, uma vez que a consequência é aumentar a renda dos capitalistas. Nesse caso, o lucro necessário para manter a taxa de investimento é menor. Como destacam Harcourt et al. (2013), se o sistema monetário for caracterizado por fundos emprestáveis, em que a poupança dos capitalistas financia o empréstimo dos trabalhadores, o teorema continua válido.

Originalmente a equação (1.13), também chamada de equação de Cambridge, é interpretada, como visto anteriormente, como determinante da distribuição de renda. Entretanto, Palley (2012) faz uma reinterpretação ao dizer que ela determina a distribuição de riqueza. Note que no crescimento de longo prazo, a cada período o estoque de capital se expande. ${ }^{17}$. Se uma das classes receber uma proporção deste estoque de capital novo diferente da porção do estoque de capital antigo, a economia não estará em equilíbrio,

15 Como a parcela do estoque de capital dos trabalhadores é proporcional a parcela da poupança desta classe:

$$
\frac{K_{w}}{K}=\frac{s_{w} s_{c}}{s_{c}-s_{w}} \frac{Y}{I}-\frac{s_{w}}{s_{c}-s_{w}}
$$

16 A taxa de juros é a remuneração pelo uso do estoque de capital que pertence aos trabalhadores

17 Supondo que as firmas não detêm estoque de capital. 
pois as parcelas nos lucros irão se alterar. Assim, como a poupança (total) é igual ao investimento (total), é preciso que o valor da poupança dos capitalistas seja exatamente a necessária para realizar a parcela do investimento(estoque de capital novo) que seja igual a sua parcela do estoque de capital antigo. Assim, seja $z=\frac{K_{c}}{K}=\frac{P_{c}}{P}$, então:

$$
z I=s_{c} z P_{c}
$$

Repare que o lado esquerdo da equação indica o investimento que os capitalistas devem 'prover' para manter constante a sua parcela no estoque de capital, enquanto que o lado direito é a poupança que eles devem ter sobre a sua renda, $P_{c}$. Como destaca Palley (2012), o fato do parâmetro de distribuição de riqueza poder ser cortado de ambos os lados da equação pode explicar a omissão da distribuição de riqueza como uma variável endógena.

A partir disso, Palley (2013) busca entender sob quais condições a política fiscal invalida o que foi apresentado por Pasinetti (1962). No caso em que o déficit é financiado pela emissão de títulos públicos, o teorema continua a valer. Assim, a equação de Pasinetti modificada é:

$$
z(I+D)=s_{c}(z P+z r B)
$$

Em que D é o valor do déficit do governo, B é a dívida do governo e r é a taxa de juros sobre os títulos públicos.

Como as parcelas da riqueza, $z$, de ambos os lados podem ser cortadas, os trabalhadores não têm como alterar a distribuição de riqueza, independentemente de variações na sua propensão a poupar. Cabe destacar, todavia, que o teorema de Pasinetti só é necessariamente válido se as proporções dos diferentes ativos, estoque de capital e títulos públicos entre as classes forem as mesmas. Além disso, se a taxa de juros for uma função das distribuições de riqueza, o teorema também deixa de ser válido. Por fim, se os capitalistas também receberem renda de salários, ou seja, não forem capitalistas 'puros', o teorema também não pode ser aplicado. Este último será melhor abordado posteriormente, quando o modelo de Palley (2012) for desenvolvido.

Palley (2013) ainda introduz algumas formas de taxação sobre as famílias de modo a tentar ver se estas alteram a validade do teorema de Pasinetti. O primeiro experimento é uma taxação lump-sum dos capitalistas que é redistribuída para os trabalhadores. Assim, a equação de Cambridge é:

$$
z I=s_{c}(z P-\tau)
$$


Tal tributação invalida o teorema de Pasinetti, pois os capitalistas deixam de ser capitalistas puros e passam a ter uma renda (negativa) de outra fonte. Dessa forma, os trabalhadores, ao mudarem a sua propensão a poupar, conseguem alterar a distribuição de riqueza. Destaca-se ainda que a introdução desta taxação exige que a parcela de lucros na economia se eleve, de modo que os capitalistas possam poupar o suficiente para realizar a sua parcela do investimento.

Caso a taxação lump-sum seja sobre os trabalhadores de forma a financiar os gastos do governo, o teorema de Pasinetti mantém-se válido. Isso ocorre pois não há nenhuma alteração de (1.21). Assim, a introdução desse tipo de taxação não altera a parcela de lucros na renda e a acumulação de capital, ainda que aumente a parcela dos capitalistas no estoque de capital.

\subsubsection{Modelos Kaleckianos com Distribuição de Riqueza}

Segundo Kalecki (1954), os trabalhadores têm uma propensão a consumir igual a unidade $^{18}$, fazendo com que, ainda que no curto prazo esta classe possua alguma riqueza, no longo prazo os capitalistas tendem a se apossar de toda ela. Isso pode ser visto a partir do que foi apresentando na seção anterior. Se $s_{w}=0,(1.13)$ equivale a (1.15). Em outras palavras, se os trabalhadores não tiverem propensão a poupar positiva, o estoque de capital detido por eles, no longo prazo, é zero. Se assim fosse, o estudo da distribuição de riqueza entre classes não faria sentido.

Assim, é necessário alterar esse pressuposto se o objetivo do trabalho é estudar esta distribuição. Nessa seção serão apresentados três modelos, Palley (2012), Palley (2016) e Dutt (2016), em que há duas classes, mas os trabalhadores poupam parte de sua renda.

Palley (2012) desenvolve um modelo Kaleckiano sem governo e de economia fechada. A parcela de lucros na renda, $\left(1-\psi_{W}\right)$, é função do poder de barganha dos trabalhadores, $\mu$, e da utilização de capacidade ${ }^{19}, u$. Além disso, o crescimento do estoque de capital é função positiva da utilização de capacidade, $u$, da taxa de lucros, $\sigma$, e do preço implícito do capital ${ }^{20}$.

$$
(1-\psi)=\psi(\mu, u)
$$

18 Kalecki não acredita que de fato que os trabalhadores consomem toda a sua renda. Neste trabalho, ele apenas simplifica a realidade.

19 Repare que a inclusão na utilização é diferente dos modelos que foram apresentados na primeira seção. Ele indica que o aumento da utilização aumenta mais a produtividade do trabalho do que o salário real. Para mais detalhes, ver Goodwin (1967) e Taylor (2004)

20 O preço implícito do capital reflete o 'q' de Tobin (Tobin e Brainard (1976)), $q=e \frac{P}{K}=q(e, \sigma)$, em que é um índice dos lucros, que indica a avaliação do mercado sobre o valor dos lucros. 


$$
g=\frac{I}{K}=g(u, \sigma, q)
$$

Os trabalhadores recebem salários, e como poupam parte da renda, também auferem lucros ${ }^{21}$, enquanto os capitalistas ganham lucros e também são remunerados como gerentes, recebendo uma fração $\Omega$ dos salários. Ambas as classes alocam de forma igual sua poupança em riqueza real, isto é, em estoque de capital, e em riqueza financeira, V. Além disso, tanto os trabalhadores como os capitalistas têm propensão a consumir positiva sobre a riqueza financeira. O valor desta riqueza acompanha a riqueza real, isto é, $V=q K$, em que $q$ é um parâmetro que indica preço implícito do capital. Dessa forma, supondo a relação capital produto de plena capacidade, $\frac{K}{Y^{*}}$ igual a unidade.

$$
\begin{gathered}
\frac{C_{w}}{K}=\beta_{w}((1-\Omega) \psi u+(1-z)(1-\psi) u)+\theta_{w}(1-z) q \\
\frac{C_{c}}{K}=\beta_{c}(\Omega \psi u+z(1-\psi) u)+\theta_{c} z q
\end{gathered}
$$

Em que $C_{w}$ é o consumo dos trabalhadores, $C_{c}$ é o consumo dos capitalistas, $\beta_{w}$ e $\beta_{c}$ são as propensões a consumir sobre a renda dos trabalhadores e capitalistas, respectivamente, $\theta_{h}$ e $\theta_{c}$ são as propensões a consumir sobre a riqueza financeira dos trabalhadores e capitalistas, respectivamente. Além disso, $0<\theta_{c}<\theta_{h}<\beta_{c}<\beta_{h}<1$

Supondo o curto prazo em que há equilíbrio no mercado de bens, $S=I$ :

$$
\begin{aligned}
& u=u\left(\beta_{w}, \beta_{c}, \theta_{h}, \theta_{c}, z, e, \mu, \Omega\right) \\
& \sigma=\sigma\left(\beta_{w}, \beta_{c}, \theta_{h}, \theta_{c}, z, e, \mu, \Omega\right) \\
& g=g\left(\beta_{w}, \beta_{c}, \theta_{h}, \theta_{c}, z, e, \mu, \Omega\right)
\end{aligned}
$$

Aumentos na propensão a consumir sobre a renda e riqueza de ambas as classes elevam a utilização de capacidade, ao elevar o consumo das classes, verificando-se o paradoxo da poupança. O mesmo ocorre quando há elevação do índice de lucros que aumenta a riqueza das classes. Elevações na proporção da riqueza detida pelos capitalistas, $z$, reduzem a utilização, já que os capitalistas têm propensão a consumir sobre a renda e riqueza mais baixas que a dos trabalhadores. Por fim, as mudanças no poder de barganha dos trabalhadores têm efeitos distintos na utilização, a depender dos resultados no investimento e no consumo, seguindo Amadeo (1987).

21 Por simplificação, vamos supor que as firmas redistribuem todo o lucro para as famílias. 
Repare que, no curto prazo, a parcela da riqueza que os capitalistas detêm é exógena. Palley (2012), no longo prazo, deixa essa variável se modificar, o que é alcançado quando a distribuição de riqueza torna-se constante. Assim, a equação de Cambridge é:

$$
z g=\left(1-\beta_{c}\right)(z(1-\psi) u+\Omega \psi)-\theta_{c} z q
$$

Dessa maneira, é possível perceber que não vale o Teorema de Pasinetti. Isso ocorre porque mudanças na propensão a consumir dos trabalhadores são capazes de afetar a utilização de capacidade. ${ }^{22}$. De modo a facilitar o entendimento disto, cabe fazer a relação do que foi obtido com a interpretação original de Pasinetti. O aumento da propensão a consumir dos trabalhadores reduz a sua parcela na riqueza (eleva $z$ ). Isso amplia a parcela do investimento que os capitalistas precisam prover para manter constante a sua porção na riqueza. E, para que isso seja possível, a taxa de lucros precisa aumentar.

Palley (2016), em um modelo parecido com Palley (2012), buscou entender como a distribuição de riqueza entre as classes impacta a distribuição de renda. Dessa forma, é possível entender quais as relações entre desigualdade de renda e crescimento econômico.

Neste modelo, contudo, não há propensão a consumir sobre a riqueza financeira, de modo que o consumo das famílias não é afetado, diretamente, pela riqueza. ${ }^{23}$. Assim:

$$
\begin{gathered}
Y_{w}=((1-\Omega) \psi+(1-z)(1-\psi)) u \\
Y_{c}=(\Omega \psi+z(1-\psi)) u \\
\varphi=\frac{Y_{c}}{Y_{w}}=\frac{\Omega \psi+z(1-\psi)}{(1-\Omega) \psi+(1-z)(1-\psi)}
\end{gathered}
$$

Em que, $Y_{w}$ e $Y_{c}$ são as rendas dos trabalhadores e capitalistas, respectivamente e $\varphi$ é a variável que mede a concentração de renda.

Além disso, o crescimento do estoque de capital é positivamente relacionado com a utilização de capacidade, com a taxa de lucros, com a parcela de lucros na renda e de dos animal spirits, sendo, portanto, uma combinação dos modelos Rowthorn (1981) e Bhaduri

22 Repare que, se os capitalistas não recebem como gerentes, $\Omega$ é igual a zero. Assim,

$$
z g=\left(1-\beta_{c}\right)(z(1-\psi) u)-\theta_{c} z q=\left(1-\beta_{c}\right)(z(1-\psi) u)-\theta_{c} z q
$$

23 Em Palley (2012) é possível perceber que a riqueza afeta o consumo de duas formas: i) diretamente, a partir da propensão a consumir positiva sobre a riqueza financeira. ii) indiretamente, ao aumentar a participação nos lucros, o que eleva a renda. 
e Marglin (1990). Por fim, a parcela de salários na renda é função apenas do poder de barganha dos trabalhadores.

$$
g=\frac{I}{K}=g(u, \sigma, \psi)
$$

No curto prazo, aumentos nas propensões a consumir elevam o crescimento econômico, mas não afetam a concentração de renda. Desta forma, não há trade-off entre crescimento e concentração de renda nessas variáveis. Já aumentos na parcela de salários que os capitalistas recebem, $\Omega$, e na parcela do estoque de capital que os capitalistas detêm, $z$, reduzem o crescimento e aumentam a parcela da renda dos capitalistas, aumentando a concentração de renda. Aqui, também observa-se que a igualdade na renda e o crescimento econômico variam no mesmo sentido. Elevações na parcela de salários na renda, $\psi$, necessariamente aumentam a igualdade da renda. Contudo, a existência de trade-off entre esta e o crescimento varia a depender do regime de demanda da economia. Se a economia for wage-led ${ }^{24}$ (profit-led), o crescimento tem direção igual (oposta) a da igualdade de renda.

No longo prazo, contudo, como a parcela que cada classe detém do estoque de capital pode variar, os resultados mudam. O aumento na propensão a consumir dos capitalistas, $\beta_{c}$, eleva a utilização de capacidade e o crescimento. Já a sua parcela de riqueza, $z$, tende a cair $^{25}$. Dessa forma, a igualdade na renda irá aumentar. Nesse caso, portanto, há uma correlação negativa entre igualdade de renda e crescimento econômico. A simetria ocorre com o aumento na propensão a consumir dos trabalhadores, $\beta_{w}$. Esta eleva a utilização de capacidade e o crescimento, mas reduz a parcela do estoque de capital detida pelos trabalhadores. Destarte, há uma ampliação no crescimento, mas há uma queda na igualdade de renda.

Ampliações na parcela de salários dos gerentes, reduzem a utilização e o crescimento, enquanto aumentam a igualdade da renda. Já aumentos na parcela de salários na renda, novamente precisam ser separados em regimes wage-led e profit-led para entender os resultados. Numa economia wage-led, a utilização e o crescimento se elevam, e a tendência é que a igualdade de renda também se eleve ${ }^{26}$ Se o regime é profit-led, há uma queda na utilização e no crescimento, a despeito do aumento na igualdade de renda.

Dutt (2016) buscou elaborar um modelo que trouxesse o debate recente que pres-

24 Aqui, para fins de simplificação, estamos ignorando o caso em que há aumento de utilização de capacidade, mas queda no crescimento do estoque de capital.

25 Repare que se o crescimento do estoque de capital se eleva, os capitalistas precisam prover mais poupança do que antes do choque para manter a sua parcela da riqueza constante. Além disso, o aumento da utilização de capacidade também aumenta a poupança dos capitalistas. Assim, se o efeito positivo no crescimento for mais fraco do que o aumento na poupança, a parcela da riqueza detida pelos capitalistas irá se elevar.

26 O caso contrário é o mesmo da nota anterior. 
tava atenção na separação daqueles que estavam no percentil superior da renda e o restante da população (Piketty (2014)), como o vivenciado em movimentos como o Occupy Wall Street. Assim, os dois grupos sociais que ele caracteriza no seu modelo são: i) o topo, que incluem não apenas os capitalistas, como também os CEOs das empresas, executivos financeiros (Bivens e Mishel (2013)) e outros profissionais que tem altíssima renda tal qual advogados, contadores e outros. ii) E o resto

O resto recebe salários e poupam parte de sua renda, acumulando uma parte do estoque de capital. Essa riqueza é emprestada para o topo, gerando um rendimento a partir de uma taxa de juros exógena, $i_{0}$. Já o topo também recebe salários, como gerentes, e tem rendimentos sobre o capital de duas formas: ii) atuando como setor financeiro, pegam emprestado o capital do resto e re-emprestam para as firmas. Assim, recebem uma taxa de juros superior a paga para o resto, com um mark-up, $\kappa$. ii) parcela dos lucros das firmas após o pagamento de salários e do juros para o capital emprestado pelo resto. Já o investimento é exógeno. Assim:

$$
\begin{gathered}
Y_{R}=w_{R} a Y+i_{0} K_{R} \\
Y_{T}=w_{t} \eta K+i_{o} \kappa K_{r}+\left(1-s_{F}\right) \Pi_{F} \\
\Pi_{F}=Y-w_{R} L_{R}-W_{T} L_{T}-i_{o}(1+\kappa) K_{R} \\
g=\bar{g}
\end{gathered}
$$

Em que $Y_{R}$ é a renda do resto, $Y_{T}$ é a renda do topo, $\Pi_{F}$ é o lucro líquido das firmas, $K_{r}$ é a o estoque de capital detido pelo resto, $L_{R}$ e $L_{T}$ são os trabalhadores do resto e do topo, respectivamente, e $s_{F}$ é a parcela dos lucros retidos pelas firmas. Por fim, $w_{r} a$ é a parcela da renda de salários do resto em proporção da renda total e $L_{T}=\eta K$, ou seja, os gerentes são uma proporção do estoque de capital.

No curto prazo, ao supor equilíbrio no mercado de bens, $S=I$ :

$$
u=u\left(g, w_{t}, \eta, s_{F}, s_{T}, s_{R}, \kappa, i_{o}, k_{R}, w_{R}, a\right)
$$

Em que $s_{R}$ e $s_{T}$ são as propensões a poupar do resto e do topo, respectivamente, e $k_{r}=\frac{K_{r}}{K}$.

Assim, aumentos em $\bar{g}$ elevam a utilização de capacidade, pois ampliam a demanda da economia. O mesmo ocorre com o crescimento da parcela do estoque de capital do resto, 
$k_{R}$, e da parcela de salários do resto em proporção da renda total, $w_{R} a$, pois a propensão a poupar desta classe é menor do que a do topo. O aumento do mark-up do serviço financeiro, $\kappa$, também amplia a utilização assim como da proporção de trabalhadores do topo e do salário do resto, pois redistribui renda das firmas para o topo. Por fim, aumentos na retenção dos lucros das firmas reduzem a utilização, ao diminuir a transferência para o topo.

As variáveis que mudam da transição do curto para o longo prazo são: a parcela da riqueza detida pelo resto, $k_{R}$, e o crescimento do estoque de capital. O primeiro, de forma muito semelhante aos modelos de Palley (2012) e Palley (2016). O segundo ocorre na seguinte dinâmica. As firmas tem um crescimento de estoque desejado, que é função dos lucros retidos pelas firmas, $s_{F} \Pi_{F}$, e da utilização de capacidade. Assim,

$$
\dot{g}=\Lambda\left(g^{d}-g\right)
$$

Em que $\Lambda$ é a velocidade de ajustamento e $g^{d}$ é o crescimento do estoque de capital desejado.

Aumentos na parcela de salários do resto em proporção da renda total tem dois efeitos. Por um lado aumentam o consumo, como visto na solução de curto prazo. Por outro lado, ao reduzir os lucros das firmas, podem reduzir o crescimento do estoque de capital desejado. A depender do tamanho dos efeitos, a utilização aumenta ou diminui, similar ao debate wage-led/profit-led apresentado no início deste capítulo. O efeito na distribuição da riqueza, assim como em Palley (2016), é também ambíguo. A renda do resto se eleva, o que aumenta a sua poupança e portanto a sua acumulação em estoques. Contudo, se o efeito direto no consumo for grande o suficiente de forma que a acumulação de estoques tenha uma ampliação significativa, o estoque de capital pode crescer mais do que a poupança do resto, diminuindo a sua parcela na riqueza.

Já elevações na propensão a poupar do resto também têm efeitos ambíguos. Pelo efeito direto, reduzem o consumo do resto. Entretanto, ao aumentar a poupança elevam o seu estoque de capital. Esta significa um maior rendimento a partir dos estoques, o que pode elevar o consumo total do resto. Se o resultado líquido do consumo for positivo, a utilização e o crescimento do capital se elevam. Caso esta acumulação de capital for suficientemente grande para elevar o estoque de capital mais do que a poupança do resto, a parcela dos estoques desta categoria irá reduzir. Em resumo, o resto tem capacidade de afetar a utilização de capacidade e a distribuição de riqueza, configurando-se a invalidade do Teorema de Pasinetti.

Repare que até aqui, nos modelos apresentados a riqueza financeira e a real estavam estritamente ligadas. Em Palley (2012), o crescimento da riqueza financeira ocorria na mesma proporção do crescimento da riqueza real, enquanto que em Dutt (2016), o setor 
financeiro só aparecia na lógica da intermediação do capital do resto para as firmas. Entretanto, como destaca Dutt

Pode ser instrutivo analisar explicitamente a relação entre fluxos e estoques não apenas em relação ao capital físico, mas também dos ativos e passivos financeiros, utilizando o que são chamados de modelos stock-flow-consistent (SFC). Todavia, esses modelos tornam-se rapidamente extremamente complicados uma vez que exigem a análise explícita de um elevado número de variáveis, e assim, necessitam o uso de técnicas de simulação. Dutt (2011b)[p.20]

Cabe destacar, por fim, que Caverzasi e Godin (2015) ao realizarem uma revisão histórica e bibliográfica dos modelos SFC entenderam que a corrente desenvolvida por Godley (Godley e Cripps (1983), Godley e Zezza (1989)) nos anos 80 é uma variante específica dos modelos pós-Keynesianos, ao buscar uma interação entre os fluxos e estoques de todos os setores da economia. Nesses modelos, o tempo tem uma característica primordial. De acordo com Santos e Zezza (2008), a literatura SFC resulta em uma relação natural e rigorosa entre períodos próximos. Em cada período, os estoques geram fluxos que aumentam os estoques, que no período seguinte gerarão novos fluxos. Destarte, a dinâmica de longo prazo desses modelos é composta por uma interdependência entre os curtos prazos anteriores e os estoques. Esta abordagem aproxima-se de outros autores como Keynes (1936) e Kalecki (1954), como destacado por Silva e Santos (2011). 


\section{Modelo e Solução de Curto Prazo}

\subsection{Panorama Geral}

O modelo aqui desenvolvido é inspirado em Palley (2012) e Godley e Lavoie (2012). Diferentemente do primeiro, o modelo possui três classes: duas de trabalhadores e uma de capitalistas. Os trabalhadores são denominados como trabalhadores menos qualificados e trabalhadores mais qualificados. Esta diferença permite entender como a redistribuição dos salários ${ }^{1}$ afeta a utilização de capacidade assim como a distribuição de renda e de riqueza.

Os capitalistas e as firmas atuam como uma única classe e, dessa forma, detêm o estoque de capital. Tal qual Godley e Lavoie (2012), o modelo introduz títulos públicos, $B_{i, t}$, que a cada período geram uma renda financeira por uma taxa de juros, $r_{t}$. Esses títulos são emitidos pelo governo, e são comprados pelos trabalhadores mais qualificados e pelos capitalistas. Aqueles que não são adquiridos pelas famílias o são pelo Banco Central. Assim, a distribuição de riqueza é composta de uma riqueza financeira de títulos públicos e moeda, $D_{i, t}$.

O modelo possui um setor governo que coleta impostos sobre salários, lucros, renda financeira e riqueza com as alíquotas, $\tau_{W, t}, \tau_{B, t}, \tau_{\pi, t}$ e $\tau_{V, t}$, respectivamente. O governo, ao contrário de Godley e Lavoie (2012), utiliza esses impostos para realizar seus gastos. Além disso, a economia é fechada e a produção é de apenas um bem, que pode ser usado tanto para consumo como para investimento. As firmas produzem de acordo com a demanda efetiva, combinando capital e trabalho com um coeficiente fixo e o preço é normalizado em 1, isto é, as variáveis aqui são reais. Por fim, não há aumento de produtividade e a oferta de trabalhadores é infinitamente elástica.

O panorama geral do modelo é apresentado nas tabelas de balanço e de transação. Os subscritos 1 , h e c denotam respectivamente os trabalhadores menos qualificados, os trabalhadores mais qualificados e os capitalistas. Por exemplo, a segunda coluna da Tabela 2 indica que os trabalhadores menos qualificados, $L_{l, t}$, recebem salário, $W_{l, t}$, e após pagar impostos, consomem toda a sua renda disponível, $C_{l, t}$. A quarta e a sexta coluna da Tabela 2 indicam que os trabalhadores mais qualificados, $L_{h, t}$ e os capitalistas possuem duas fontes de renda: ambos recebem rendimentos a partir dos títulos públicos, mas os primeiros recebem salários, $W_{h, t}$, enquanto os últimos recebem lucros, $\left(1-\psi_{W, t}\right) Y_{t}$. Estas

1 Cabe destacar que os salários dos trabalhadores tem pouca relação com a qualificação dos mesmos. De forma geral, é o setor que o trabalhador está envolvido que determina se o salário é mais alto ou mais baixo. Contudo, como nesse trabalho a economia produz um único bem será feita essa simplificação na determinação salarial. 
duas classes poupam parte de sua renda, acumulando riqueza financeira a cada período como as Tabelas 1 e 2 mostram.

Tabela 1 - Matriz de Balanços

\begin{tabular}{|c|c|c|c|c|c|c|}
\hline & \multicolumn{2}{|c|}{ Famílias } & Governo & Banco Central & Total \\
\hline Estoques & Trabalhadores menos qualificados & Trabalhadores Mais Qualificados & Capitalistas/Firmas & & & \\
\hline Moeda & 0 & $D_{h}$ & $D_{c}$ & & $-D$ & 0 \\
Títulos Públicos & 0 & $B_{h}$ & $B_{c}$ & $-B$ & $B_{c b}$ & 0 \\
Estoque de Capital & & $V_{h}$ & $V_{c}+K$ & $-B$ & & $K$ \\
Total & & & & $B_{c b}-D+K$ \\
\hline
\end{tabular}




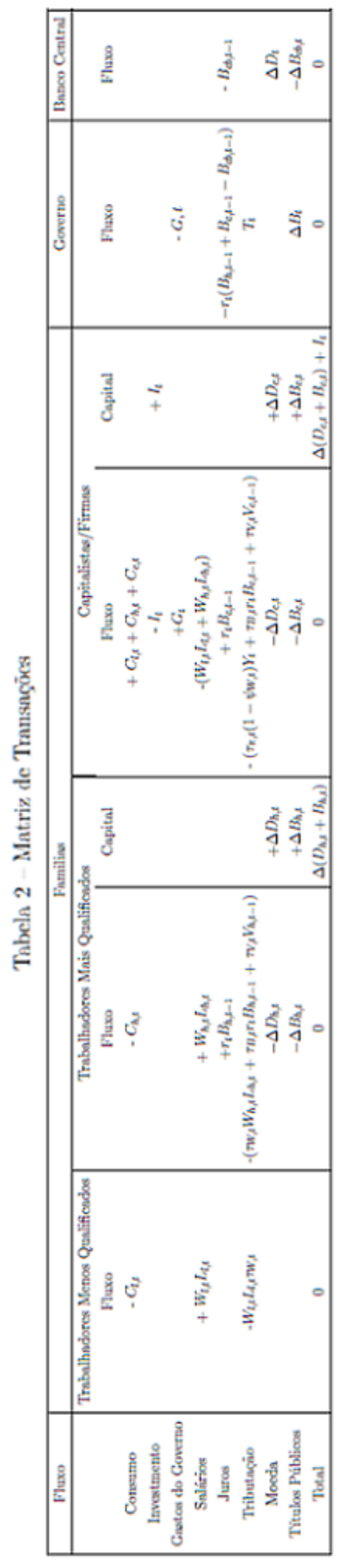




\subsection{Modelo}

\subsubsection{Famílias}

A renda da economia é distribuída entre os trabalhadores, que recebem salários, $Y_{W, t}=W_{l, t} L_{l, t}+W_{h, t} L_{h, t}$, e capitalistas, que recebem lucros, $Y_{\pi, t}=\left(1-\psi_{W, t}\right) Y_{t}$. Assim, $Y_{t}=Y_{W, t}+Y_{\pi, t}$

Em que $\psi_{W, t}$ é a parcela da renda da economia distribuída em salários.

\subsubsection{Trabalhadores Menos Qualificados}

Os trabalhadores menos qualificados recebem salários e os consomem totalmente, de acordo com o pressuposto clássico. Entretanto, parte da renda proveniente dos salários é apropriada pelo governo a partir de uma alíquota, $\tau_{W, t}$.

$$
Y_{D l, t}=C_{l, t}=\left(1-\tau_{W, t}\right) \psi_{W, t} \psi_{L, t} Y_{t}
$$

Em que $\psi_{L, t}$ é a fração dos salários que os trabalhadores menos qualificados recebem em relação a toda renda dos salários, $Y_{W, t}$.

\subsubsection{Trabalhadores Mais Qualificados}

Os trabalhadores mais qualificados representam aqueles que possuem um salário mais alto, $W_{h, t}>W_{l, t}$, porque estão inseridos em setores mais produtivos. O governo tributa tanto os salários como a renda financeira a alíquotas, $\tau_{W, t}$ e $\tau_{B, t}$, respectivamente. Ademais, a riqueza financeira do período anterior ${ }^{2}, V_{h, t-1}$,também é tributada a uma alíquota, $\tau_{V, t}$.

$$
Y_{D h, t}=\left(1-\tau_{W, t}\right)\left(1-\psi_{L, t}\right) \psi_{W, t} Y_{t}+r_{t}\left(1-\tau_{B, t}\right) B_{h, t-1}-\tau_{V, t} V_{h, t-1}
$$

Devido a essa renda superior, os trabalhadores mais qualificados consomem apenas parte da sua renda disponível, i.e, sua propensão a consumir sobre a renda disponível, $\beta_{h, t}$, é menor do que 1, acumulando riqueza ao longo tempo. Por fim, as decisões de consumo também são sensíveis ao tamanho da riqueza por uma propensão, $\theta_{h, t}$.

$$
\begin{gathered}
C_{h, t}=\beta_{h, t} Y_{D h, t}+\theta_{h, t} V_{h, t-1} \\
S_{h, t}=Y_{D h, t}-C_{h, t}
\end{gathered}
$$

2 Os estoques são determinados pelos fluxos do período. Dessa forma, para evitar sobredeterminação todos os estoques nas equações serão aqueles do início do período. 
Assim como em Godley e Lavoie (2012)[ch. 4], a riqueza dos trabalhadores mais qualificados é a soma da riqueza acumulada no período anterior e da poupança corrente. A sua alocação, que é feita em moeda, $D_{h, t}$, e títulos públicos, $B_{h, t}$, é revista a cada período e depende da taxa de juros, $r_{t}$, da renda disponível, da riqueza e de um parâmetro exógeno.

$$
\begin{gathered}
V_{h, t}=V_{h, t-1}+S_{h, t} \\
\frac{B_{h, t}}{V_{h, t}}=\lambda_{0, h, t}+\lambda_{1, h, t} r_{t}-\lambda_{2, h, t} \frac{Y_{D h, t}}{V_{h, t}} \\
V_{h, t}=B_{h, t}+D_{h, t}
\end{gathered}
$$

Em que $\lambda_{0, h, t}>0, \lambda_{1, h, t}>0, \lambda_{2, h, t}>0$

\subsubsection{Capitalistas/Firmas}

Os capitalistas tomam as suas decisões de acordo com a seguinte sequência.: i) Investimento, $I_{t}$. ii) Consumo, $C_{c, t}$ iii) Alocação da sua riqueza em moeda e títulos públicos.

De acordo com Rowthorn (1981) e Dutt (1984), a taxa de investimento bruto do capital físico é uma função positiva do animal spirits, da taxa de lucros e da utilização de capacidade $^{3}$. Além disso, o estoque de capital deprecia a uma taxa $\xi$.

$$
I_{t}=\gamma_{0, t} K_{t-1}+\gamma_{1, t}\left(1-\psi_{W, t}\right) Y_{t}+\gamma_{2, t} Y_{t}
$$

Em que $\gamma_{0, t}>0, \gamma_{1, t}>0, \gamma_{2, t}>0$

Os capitalistas recebem os lucros das firmas, que são tributados pelo governo a uma alíquota $\tau_{\pi, t}$. Além disso, a renda financeira e a riqueza financeira do período anterior, $V_{c, t-1}$, também são taxados a alíquotas $\tau_{B, t}$ e $\tau_{V, t}$ respectivamente.

$$
Y_{D c, t}=\left(1-\tau_{\pi, t}\right)\left(1-\psi_{W, t}\right) Y_{t}+r_{t}\left(1-\tau_{B, t}\right) B_{c, t-1}-\tau_{V, t} V_{c, t}-I_{t}
$$

Em razão da renda dos capitalistas ser superior à renda dos trabalhadores mais qualificados, sua propensão a consumir é mais baixa, i.e, $\beta_{c}<\beta_{h}<1$. E como nos trabalhadores mais qualificados, o tamanho da riqueza dos capitalistas também tem um

3 A equação (2.8) equivale as equações de Rowthorn e Dutt em nível, isto é, multiplicando pelo estoque de capital do início do período 
efeito psicológico no seu consumo, representada pela propensão marginal a consumir sobre a riqueza $\theta_{c}$, que é menor ou igual a $\theta_{h}$.

$$
\begin{gathered}
C_{c, t}=\beta_{c, t} Y_{D c, t}+\theta_{c, t} V_{c, t-1} \\
S_{c, t}=Y_{D c, t}-C c, t
\end{gathered}
$$

Dessa forma, os capitalistas acumulam riqueza ao longo do tempo, alocando em títulos públicos, $B_{c, t}$, que rendem juros a uma taxa, $r_{t}$, a cada período e em moeda, $D_{c, t}$. Tal qual os trabalhadores mais qualificados, a alocação de riqueza dos capitalistas é revista a cada período e depende da taxa de juros, $r_{t}$, da sua renda disponível, de sua riqueza, e de um parâmetro exógeno.

$$
\begin{gathered}
V_{c, t}=V_{c, t-1}+S_{c, t} \\
\frac{B_{c, t}}{V_{c, t}}=\lambda_{0, c, t}+\lambda_{1, c, t} r_{t}-\lambda_{2, c, t} \frac{Y_{D c, t}}{V_{c, t}} \\
V_{c, t}=B_{c, t}+D_{c, t}
\end{gathered}
$$

Em que $\lambda_{0, c, t}>0, \lambda_{1, c, t}>0, \lambda_{2, c, t}>0$

\subsubsection{Banco Central}

$$
\begin{gathered}
B_{c b, t}=B_{s, t}-B_{h, t}-B_{c_{t}} \\
r_{t}=\overline{r_{t}}
\end{gathered}
$$

O Banco Central adquire os títulos públicos residuais, i.e, compra todos os títulos públicos que o governo emite, $B_{s, t}$, e que as famílias não desejam possuir, dada uma taxa de juros. Além disso, como o lucro do Banco Central é transferido para o governo, os juros pagos por esses títulos são inteiramente compensados.

\subsubsection{Governo}

$$
G_{t}+r_{t}\left(B_{h, t-1}+B_{c, t-1}+B_{c b, t}\right)=T_{t}+\Delta B_{t}+r_{t} B_{c b, t}
$$




$$
G_{t}=\omega_{t} Y_{t}+T_{t}
$$

$$
G_{t}=\tau_{W, t} \psi_{W, t} Y_{t}+\tau_{\pi, t}\left(1-\psi_{W, t}\right) Y_{t}+r_{t} \tau_{B, t}\left(B_{h, t-1}+B_{c, t-1}\right)+\tau_{V, t}\left(V_{h, t-1}+V_{c, t-1}\right)+\omega_{t} Y_{t}
$$

Os gastos do governo, $G_{t}$, mais os pagamentos de juros a partir dos títulos públicos precisam de uma contrapartida de impostos, de lucros do Banco Central ou de emissão de dívida. Além disso, a decisão de gasto do governo é determinada por um parâmetro exógeno, $\omega_{t}$, que representa uma meta de déficit primário em proporção da renda total. Destarte, o gasto do governo é determinado endogenamente.

\subsection{Equilíbrio de Curto Prazo}

A solução de curto prazo envolve encontrar a utilização de capacidade, $u$, que equilibra o mercado de bens. Exceto o estoque de capital do período anterior, $K_{t-1}$, a riqueza financeira das duas classes poupadoras do período anterior, $V_{h, t-1}$ e $V_{c, t-1}$, e os títulos públicos do período anterior retidos pelas famílias, $B_{h, t-}$ e $B_{c, t-}$, as outras variáveis são exógenas. Assim, a utilização de capacidade de curto prazo é determinada pelo deficit fiscal, $\omega_{t}$, pela distribuição funcional da renda, $\psi_{W, t}$, pela proporção dos salários dos trabalhadores menos qualificados no total de salários, $\psi_{L, t}$, pelas alíquotas sobre os salários, $\tau_{W, t}$, sobre os lucros, $\tau_{\pi, t}$, sobre a renda financeira, $\tau_{B, t}$, e sobre a riqueza financeira, $\tau_{V, t}$, pelas propensões a consumir sobre a renda disponível, $\beta_{h, t}$ e $\beta_{c, t}$, pelas propensões a consumir sobre a riqueza, $\theta_{h, t}$ e $\theta_{c, t}$, pelos parâmetros da função investimento, $\gamma_{0, t}, \gamma_{1, t}$ e $\gamma_{2, t}$, pela taxa de juros, $r_{t}$, e pela razão capital-produto, $v$.

$$
D A=Y_{t}=C_{t}+I_{t}+G_{t}=C_{l, t}+C_{h, t}+C_{c, t}+I_{t}+G_{t}
$$

$$
\begin{array}{r}
u^{*}=u_{s r}\left(\beta_{h, t}, \beta_{c, t}, \theta_{h, t}, \theta_{c, t}, \gamma_{0, t}, \gamma_{1, t}, \gamma_{2, t}, \tau_{W, t}, \tau_{\pi, t}, \tau_{B, t}, \tau_{V, t}, \psi_{W, t}, \psi_{L, t}, \omega_{t}, r_{t}, v\right. \\
\left.b_{h, t-2}, b_{c, t-2}, v_{h, t-2}, v_{c, t-2}\right)
\end{array}
$$

Em que $u=\frac{Y_{t}}{Y_{t}^{f c}}, Y^{f c}$ é o produto de plena capacidade e $v$ é a razão capital-produto. Além disso, $v_{h, t}=\frac{V_{h, t}}{K_{t-1}}, v_{c, t}=\frac{V_{c, t}}{K_{t-1}}, b_{h, t}=\frac{B_{h, t}}{K_{t-1}}$ e $b_{c, t}=\frac{B_{c, t}}{K_{t-1}}$

Suponto que vale a Estabilidade Keynesiana, a sensibilidade dos vazamentos de demanda deve ser superior à sensibilidade da soma das injeções de demanda. 
Então,

$$
\begin{array}{r}
\psi_{W, t}\left(\psi_{L, t}+\left(1-\psi_{L, t}\right)\left(\beta_{h, t}\left(1-\tau_{W, t}\right)+\tau_{W, t}\right)\right)+\left(1-\psi_{W, t}\right)\left(\beta_{c, t}\left(1-\tau_{\pi, t}\right)+\tau_{\pi, t}+\gamma_{1, t}\left(1-\beta_{c, t}\right)\right) \\
+\gamma_{2, t}\left(1-\beta_{c, t}\right)+\omega_{t}<1
\end{array}
$$

A Tabela 3 expressa os efeitos de choques nas variáveis exógenas sobre utilização de capacidade. O último parâmetro é um indicativo da proporção da riqueza dos trabalhadores mais qualificados na riqueza financeira total, $\varphi_{V, t}=\frac{V_{h, t}}{V_{h, t}+V_{c, t}}$.

Tabela 2 - Efeito de choques nas varáveis exógenas na utilização

\begin{tabular}{|l|l|}
\hline & $u^{*}$ \\
$\omega_{t}$ & + \\
$\tau_{W, t}$ & + \\
$\tau_{\pi, t}$ & + \\
$\tau_{B, t}$ & + \\
$\tau_{V, t}$ & + \\
$\beta_{h, t}$ & + \\
$\beta_{c, t}$ & + \\
$\theta_{h, t}$ & + \\
$\theta_{c, t}$ & + \\
$\gamma_{0, t}$ & + \\
$\gamma_{1, t}$ & + \\
$\gamma_{2, t}$ & + \\
$r_{t}$ & + \\
$\psi_{W, t}$ & $+/-$ \\
$\psi_{L, t}$ & + \\
$\psi_{B, t-1}$ & + \\
$\varphi_{V, t-1}$ & + \\
\hline
\end{tabular}

A utilização de curto prazo é positivamente relacionada pelas propensões a consumir sobre a renda disponível, $\beta_{h}$ e $\beta_{c}$, e pelas propensões a consumir sobre a riqueza, $\theta_{h}$ e $\theta_{c}$. Assim, verifica-se a validade do paradoxo da poupança. A distribuição dos salários, $\psi_{L}$, em favor da classe mais pobre tem um efeito positivo na utilização, pois essa classe tem uma propensão maior a consumir. Pelo mesmo motivo, um aumento na proporção de títulos públicos do período anterior detidos pelos trabalhadores mais qualificados , $\psi_{B, t-1}$, e na proporção da riqueza dos trabalhadores mais qualificados na riqueza financeira total do período anterior, $\varphi_{V, t-1}$, também elevam a utilização. A elevação das alíquotas acarretam em um aumento na utilização, uma vez que a redução do consumo pelas famílias é menor do que o aumento do gasto do governo. Por fim, a elevação da taxa de juros amplia o nível de utilização como resultado do aumento da renda financeira das famílias.

O impacto de uma maior parcela de salários na renda, $\psi_{W}$, é ambíguo. Esta ele- 
vação afeta positivamente a utilização quando:

$$
\psi_{L, t}+\left(1-\psi_{L, t}\right)\left(\beta_{h, t}\left(1-\tau_{W, t}\right)+\tau_{W, t}\right)>\beta_{c, t}\left(1-\tau_{\pi, t}\right)+\tau_{\pi, t}+\gamma_{1, t}\left(1-\beta_{c, t}\right)
$$

Esta desigualdade mostra que o aumento dos salários frente aos lucros aumenta mais o consumo dos trabalhadores e a arrecadação do governo sobre salários do que reduz o consumo dos capitalistas, o investimento e a arrecadação do governo sobre lucros. Quando (2.23) vale, a economia possui um regime de demanda wage-led. Caso contrário, a economia é profit-led.

Cabe destacar a diferença desta ambiguidade em relação aos modelos de Amadeo (1987) e Bhaduri e Marglin (1990) que foram apresentados no capítulo 1. A ambiguidade do primeiro deve-se à inclusão da propensão a poupar positiva dos trabalhadores, enquanto que no segundo, ocorre devido a inclusão direta da parcela de lucros no investimento. Na solução do trabalho aqui desenvolvido, as mudanças de regime de demanda não são consequências apenas da propensão a poupar dos trabalhadores mais qualificados ser menor que a unidade. No caso deste modelo, há duas diferenças que impactam o regime de demanda da economia: a distribuição de salários, entre trabalhadores mais qualificados e menos qualificados, e a inclusão do governo.

Uma vez que os trabalhadores menos qualificados tem propensão a consumir superior a dos trabalhadores mais qualificados, uma maior apropriação da renda salarial pelos primeiros aumenta a propensão média a consumir dos trabalhadores. Assim, aumentos na parcela dos salários na renda elevam mais a demanda efetiva quando a fração dos salários dos trabalhadores menos qualificados, $\psi_{L}$, é maior. Dessa forma, a economia tem mais chance de ser wage-led se os salários são mais igualmente distribuidos, como acontece em Palley (2015).

Já a inclusão do governo faz com que maiores alíquotas de salários aumentem a chance da economia ser wage-led, ocorrendo o contrário para elevações na alíquota sobre os lucros ${ }^{4}$. Isso ocorre porque, pela regra do gasto do governo, a propensão a consumir do governo sobre a sua renda é igual a um, enquanto que tanto os trabalhadores mais qualificados como os capitalistas tem propensão a consumir sobre a renda disponível menor que a unidade.

4 Repare por (2.23) que o lado esquerdo da equação pode ser reescrito como $\beta_{c, t}+\tau_{\pi, t}\left(1-\beta_{c, t}\right)+\gamma_{1, t}(1-$ $\left.\beta_{c, t}\right)$. Como $\beta_{c, t}$ é menor do que 1 , aumentos na alíquotas sobre os lucros, $\tau_{\pi, t}$, necessariamente elevam o lado esquerdo da desigualdade. 



\section{Simulações}

\subsection{Introdução}

Como visto no capítulo anterior, na solução de curto prazo os estoques foram tomados como pré-determinados. Assim, neste capítulo os estoques podem variar e o equilíbrio de longo prazo ocorre quando esses crescem a uma mesma taxa.

Para melhor analisar a dinâmica de longo prazo, o produto foi dividido em quatro fontes de determinação de demanda: i) distribuição funcional e distribuição entre salários, doravante salários e lucros; ii) induzido pela renda; iii) estoques e iv) renda financeira.

A primeira está associada ao consumo das famílias pela renda disponível relacionada aos salários e lucros, ao gasto do governo a partir dessa tributação e ao investimento induzido pela parcela de lucros na renda. Esta fonte contribui para entender como a distribuição funcional da renda e a distribuição de salários, ao afetarem a renda dos trabalhadores e capitalistas, geram consequências para o produto.

$$
\begin{aligned}
Y_{w p, t}= & \left(\psi_{W, t}\left(\left(1-\tau_{W, t}\right) \psi_{L, t}+\beta_{h, t}\left(1-\tau_{W, t}\right)\left(1-\psi_{L, t}\right)+\tau_{W, t}\right)\right. \\
& \left.+\left(1-\psi_{W, t}\right)\left(\beta_{c, t}\left(1-\tau_{\pi, t}\right)+\tau_{\pi, t}+\gamma_{1, t}\left(1-\beta_{c, t}\right)\right)\right) Y_{t}+
\end{aligned}
$$

A segunda está associada a meta de deficit fiscal e ao investimento induzido pela demanda. Dessa forma, pode-se perceber que as duas primeiras fontes de determinação da demanda não possuem variáveis com taxas de crescimento diferentes na transição entre no curto prazo e o longo prazo, a exceção do produto. A separação entre essas fontes busca apenas facilitar o entendimento nos choques que serão vistos adiante, mas na prática, ambas podem ser reunidas em um grupo maior: induzidas pelo produto da economia.

$$
Y_{i, t}=\left(\omega_{t}+\gamma_{2, t}\left(1-\beta_{c, h}\right)\right) Y_{t}
$$

A terceira está associada ao consumo das famílias a partir da riqueza, à queda no consumo das famílias a partir da tributação desse estoque ${ }^{1}$, ao gasto do governo derivado dessa tributação e ao investimento realizado devido ao estoque de capital do período anterior. Esta divisão busca captar como a riqueza de cada classe ao crescer a uma taxa

1 De acordo com (2.2) e (2.9), a renda disponível das famílias é reduzido pela riqueza do período anterior. 
diferente das demais impacta a demanda, tanto via consumo como via gasto do governo.

$$
Y_{s, t}=V_{h, t-1}\left(\theta_{h, t}+\tau_{V, t}\left(1-\beta_{h, t}\right)\right)+V_{c, t-1}\left(\theta_{c, t}+\tau_{V, t}\left(1-\beta_{c, t}\right)+\tau_{V, t}\right)+\gamma_{0, t}\left(1-\beta_{c, t}\right) K_{t-1}
$$

A quarta está associada ao consumo das famílias sobre a renda financeira e ao gasto do governo derivado da tributação deste tipo de renda. Cabe ressaltar que esta fonte está diretamente relacionada à terceira fonte, motivo pela qual serão apresentadas conjuntamente nas simulações. Note que a riqueza pode afetar o produto por quatro canais: a) diretamente pelo consumo sobre a riqueza, b) pelos impostos coletados sobre a riqueza, c) pelo consumo da renda financeira d) pela tributação sobre a renda financeira.

Repare que estas duas últimas fontes de determinação da demanda indicam como a riqueza é uma realimentadora de demanda. As famílias, ao pouparem parte de sua renda, transformam essa poupança em riqueza financeira. Assim, nos períodos seguintes, essa renda não consumida reinjeta demanda na economia tanto ao aumentar a renda disponível por meio do incremento da renda financeira como da própria propensão a consumir sobre a riqueza financeira. Portanto, a separação da parcela da renda financeira e da parcela dos estoques foi realizada com o objetivo de ter uma análise mais refinada de como a riqueza pode afetar o produto.

$$
Y_{f i, t}=r_{t}\left(B_{h, t-1}\left(\beta_{h}\left(1-\tau_{B, t}\right)+\tau_{B, t}\right)+B_{c, t-1}\left(\beta_{c}\left(1-\tau_{B, t}\right)+\tau_{B, t}\right)\right)
$$

Esse capítulo, está dividido em quatro seções. Inicialmente são apresentadas as equações dinâmicas das variáveis endógenas, a riqueza financeira dos trabalhadores mais qualificados e dos capitalistas, os títulos públicos pertencentes as famílias e ao Banco Central e o capital físico. Posteriormente, os valores iniciais de um estado de crescimento estacionário, i.e., $g_{k, t}=g_{k, t-1}$, são encontrados, a partir de uma calibragem que esteja de acordo com estudos empíricos ${ }^{2}$. Com tais valores é possível realizar simulações com choques nas variáveis $^{3}$ : i) comportamentais, $\beta_{h}, \beta_{c}, \theta_{h}, \theta_{c}$, ii) distributivas, $\psi_{L}$ e $\psi_{W}$ e iii) de política econômica, $r, \omega$, e $\tau_{V}$. Essas simulações permitem entender quais as correlações e causalidades entre a utilização de capacidade, a proporção da riqueza dos trabalhadores

$\overline{2}$ Para o conjunto de experimentos que foi realizado há um comportamento das variáveis que caracterizam que para esse conjunto de parâmetros e valores iniciais o modelo é estável.

3 Essa divisão foi feita apenas para facilitar o entendimento e pela construção do modelo, contudo como destaca Lavoie (2014) as escolhas dos indivíduos são afetadas quando a renda se eleva. Assim, as variáveis denominadas aqui de comportamentais seriam endogenamente determinadas, sendo afetadas portanto pelas duas seguintes. Além disso as variáveis distributivas em muitos modelos também são endogenamente determinadas, por exemplo a distribuição funcional da renda é função positiva da utilização de capacidade em Palley (2014). Por fim, as políticas econômicas também podem ser consideradas endógenas, pois o aumento de algum imposto poderia ser facilitado em uma economia em crescimento. 
mais qualificados na distribuição de riqueza e a parcela da renda dos trabalhadores na repartição líquida da renda. Por fim, é feita uma discussão a partir dos resultados obtidos.

\subsection{Equações Dinâmicas}

Ao deixar as variáveis pré-determinadas no curto prazo, foram resolvidas as equações dinâmicas do estoque de capital (3.5); dívida do governo (3.6); riqueza financeira dos trabalhadores mais qualificados(3.7) e dos capitalistas(3.8); títulos públicos retidos pelo Banco Central (3.11), pelos trabalhadores mais qualificados (3.9) e pelos capitalistas(3.10); normalizadas pelo estoque de capital do período anterior, $K_{t-1}$.

Por $(2.8)$

$$
g_{k, t}=\gamma_{0, t}-\xi+\left(\gamma_{1, t}\left(1-\psi_{W, t}\right)+\gamma_{2, t}\right) \frac{u^{*}}{v}
$$

Em que $g_{k, t}=\frac{I_{t}}{K_{t-1}}-\xi$

A taxa de crescimento do estoque de capital, $g_{k, t}$ é positivamente relacionada ao animal spirit e a utilização de capacidade, $u$, enquanto a taxa de depreciação, $\xi$ e a parcela de salários na renda a impacta negativamente.

Substituindo (2.18) e (2.15) em (2.17):

$$
b_{s, t}=\frac{\left(1+r_{t}\right) b_{s, t-1}-r_{t} b_{c b, t-1}}{1+g_{k, t-2}}+\omega_{t} \frac{u^{*}}{v}
$$

Em que $b_{s, t}=\frac{B_{s, t}}{K_{t-1}}$ and $b_{c b, t}=\frac{B_{c b, t}}{K_{t-1}}$.

A oferta total de títulos públicos, $b_{s, t}$, é positivamente relacionada com os títulos emitidos anteriormente, $b_{s, t-1}$, com a taxa de juros, $r$, e com a meta de déficit primário em proporção do produto, $\omega$. Contudo, quanto mais o Banco Central possuir esse títulos, $b_{c b, t}$ menor é a emissão de títulos públicos.

Substituindo (2.2) e (2.3) em (2.4), e esta em (2.5) e normalizando:

$$
\begin{array}{r}
v_{h, t}=\frac{v_{h, t-1}\left(1-\theta_{h, t}-\tau_{v, t}\left(1-\beta_{h, t}\right)\right)+b_{h, t-1}\left(1-\beta_{h, t}\right) r_{t}\left(1-\tau_{B, t}\right)}{1+g_{k, t-2}} \\
+\left(1-\beta_{h, t}\right) \psi_{W, t}\left(1-\psi_{L, t}\right)\left(1-\tau_{W, t}\right) \frac{u^{*}}{v}
\end{array}
$$

A riqueza financeira dos trabalhadores mais qualificados, $v_{h, t}$, como visto no capítulo 2 , é a soma da sua riqueza anterior, $v_{h, t-1}$, e da poupança no período corrente, $S_{h, t}$. Assim, este estoque é positivamente relacionado com a riqueza alocada em títulos no período anterior, $b_{h, t-1}$, com a taxa de juros, $r$, com a parcela de salários na renda, 
$\psi_{W}$, e com a utilização de capacidade, $u$, pois elevam a a renda disponível desta classe, aumentando a poupança. Uma maior igualdade na distribuição de salários, $\psi_{L}$, nas alíquotas sobre a riqueza, $\tau_{V}$, sobre a renda financeira, $\tau_{B}$, e sobre a renda dos salários, $\tau_{W}$ ao reduzirem os rendimentos, contraem a poupança, diminuindo a riqueza dos trabalhadores mais qualificados. Por fim, as propensões a consumir sobre a renda, $\beta_{h}$, e sobre a riqueza, $\theta_{h}$ do trabalhadores mais qualificados também contribuem negativamente na acumulação de riqueza desta classe.

Substituindo (2.9) e (2.10) em (2.11), e esta em (2.12) e normalizando:

$$
\begin{aligned}
v_{c, t}= & \frac{v_{c, t-1}\left(1-\theta_{c, t}-\tau_{v, t}\left(1-\beta_{c, t}\right)\right)+b_{c, t-1}\left(1-\beta_{c, t}\right) r_{t}\left(1-\tau_{B, t}\right)}{1+g_{k, t-2}} \\
& +\left(1-\beta_{c, t}\right)\left(\left(\left(1-\psi_{W, t}\right)\left(\left(1-\tau_{\pi, t}\right)-\gamma_{1, t}\right)-\gamma_{2, t}\right) \frac{u^{*}}{v}-\gamma_{0, t}\right)
\end{aligned}
$$

Como na riqueza dos trabalhadores mais qualificados, a riqueza dos capitalistas, $V_{c, t}$, é a soma do acumulado nos períodos anteriores, $V_{c, t-1}$, mais a poupança no período corrente, $S_{c, t}$. Assim, a riqueza dos capitalistas é positivamente relacionada com a riqueza alocada, por esta classe, em títulos públicos nos período anterior, $B_{c, t-1}$ e com a taxa de juros, $r$, por elevar a poupança proveniente da renda financeira. Já as alíquotas sobre a riqueza, $\tau_{V, t}$, sobre a renda financeira, $\tau_{B}$, e sobre os lucros, $\tau_{\pi}$ reduzem a riqueza dos capitalistas. Aumentos na parcela de salários na renda, $\psi_{W}$ ao reduzirem os lucros tem efeito negativo ${ }^{4}$ na acumulação de riqueza. Elevações nas propensões a consumir sobre a renda, $\beta_{c}$ e sobre a riqueza dos capitalistas, $\theta_{c}$, ao diminuírem a poupança, também impactam negativamente a riqueza dos capitalistas. Por fim, elevações nos parâmetros da função investimento, por aumentarem a acumulação do estoque de capital, (3.5), reduzem a renda disponível dos capitalistas, contraindo a poupança e a riqueza desta classe.

Substituindo (2.2) em (2.6), e normalizando:

$b_{h, t}=\left(\lambda_{0, h, t}+r_{t} \lambda_{1, h, t}\right) v_{h, t}-\lambda_{2, h, t}\left(\psi_{W, t}\left(1-\psi_{L, t}\right)\left(1-\tau_{W, t}\right) \frac{u^{*}}{v}+\frac{r_{t}\left(1-\tau_{B, t}\right) b_{h, t-1}-\tau_{V, t} v_{h, t-1}}{1+g_{k, t-2}}\right)$

A quantidade de títulos públicos que os trabalhadores mais qualificados detém, $B_{h, t}$ é positivamente relacionada coma a parcela de salários na renda, $\psi_{W}$. na utilização, $u$, nos títulos públicos detidos pelos trabalhadores mais qualificados no período anterior, $B_{h, t-1}$, reduzem a quantidade de títulos públicos detidos pelos trabalhadores mais qualificados no período corrente. Já elevações nas alíquotas sobre os salários, $\tau_{W}$, sobre a renda financeira, $\tau_{B}$, e sobre a riqueza, $\tau_{V}$, assim como uma maior igualdade na distribuição de salarial, $\psi_{L}$, elevam a quantidade de títulos públicos detidos pelos trabalhadores mais qualificados.

Supondo que $\tau_{\pi}+\gamma_{1}<1$ 
Substituindo (2.9) em (2.13) e normalizando:

$$
\begin{array}{r}
b_{c, t}=\left(\lambda_{0, c, t}+r_{t} \lambda_{1, c, t}\right) v_{h, t}-\lambda_{2, c, t}\left(\left(\left(1-\psi_{W, t}\right)\left(\left(1-\tau_{\pi, t}\right)-\gamma_{1, t}\right)-\gamma_{2, t}\right) \frac{u^{*}}{v}-\gamma_{0, t}\right. \\
\left.+\frac{r_{t}\left(1-\tau_{B, t}\right) b_{c, t-1}-\tau_{V, t} v_{c, t-1}}{1+g_{k, t-2}}\right)
\end{array}
$$

A quantidade de títulos públicos que os trabalhadores capitalistas detém, $B_{c, t}$, é positivamente relacionada com a utilização, $u$, e nos títulos públicos detidos pelos capitalistas no período anterior, $B_{c, t-1}$, ampliam os títulos públicos detidos pelos trabalhadores mais qualificados no período corrente. Já elevações nas alíquotas sobre os lucros, $\tau_{\pi}$, sobre a renda financeira, $\tau_{B, t}$, e sobre a riqueza, $\tau_{V}$, e um aumento na parcela de salários na renda, $\psi_{W}$, reduzem os títulos públicos detidos pelos capitalistas.

Finalmente, substituindo (3.10) e (3.6) em (2.15) e normalizando:

$$
b_{c b, t}=b_{s, t}-b_{h, t}-b_{c, t}
$$

Tal que $b_{c, t}=\frac{B_{c, t}}{K_{t-1}}$

Como os títulos públicos na carteira do Banco Central, $B_{c b, t}$, são um resíduo. O seu valor depende do quanto é emitido pelo governo, $B_{s, t}$, mas não está na posse das famílias, $B_{h, t}$ e $B_{c, t}$.

\subsection{Valores Iniciais}

A partir de um estado de crescimento estacionário, i.e, $g_{k, t}=g_{k, t-1}$, os valores iniciais compatíveis com um regime de demanda wage-led foram computados. Os parâmetros de propensão a consumir sobre a renda disponível são inspirados em Leite (2014). O autor ao utilizar dados da Pesquisa de Orçamentos Familiares (POF) considera que a propensão a consumir sobre a renda é 0,913 para os $92 \%$ mais pobres e 0,618 para os $8 \%$ mais ricos. Já a propensão a consumir sobre a riqueza financeira varia ente 0,02 e 0,07 em Catte et al. (2004), Boone, Giorno e Richardson (1998), Altissimo et al. (2005), Sousa (2009) e Barrell, Costantini e Meco (2015). Sousa (2009) e Altissimo et al. (2005) discordam sobre a importância da riqueza financeira em relação à imobiliária no consumo, foram escolhidos parâmetros entre esses valores. Além disso, cada classe tem uma propensão a consumir sobre a riqueza diferente, seguindo Zeldes (1989), que acredita que a distribuição de riqueza afeta o valor desse parâmetro. Ainda assim, nas simulações, a diferença entre os parâmetros é relaxada para dar uma robustez maior dos resultados.

A taxa de juros de $4 \%$ foi escolhida considerando a taxa de juros de longo prazo em valores reais. Como a taxa de juros é superior a taxa de crescimento econômico, para 
estabilizar a dívida no longo prazo, foi necessário colocar uma meta de superávit primário positiva. A distribuição funcional da renda utilizada segue de Neto e Saboia (2014) que estimam uma participação de $43 \%$ das remunerações do PIB nominal. Os valores dos parâmetros da escolha de portfólio das classes foram escolhidos de forma a ter uma alta participação de títulos públicos entre as classes e que os capitalistas a tenham superior aos trabalhadores mais qualificados. Por fim, os demais parâmetros foram escolhidos de modo que: i) a utilização de capacidade ficasse em torno de 0,8 ii) as proporções do consumo do governo, consumo das famílias e formação bruta de capital fixo fossem próximas aos computados nas contas nacionais do Brasil em 2017.

Já os valores compatíveis com o regime de demanda profit-led foram alcançados partindo da uma economia wage-led, e mudando as seguintes variáveis exógenas: propensão a consumir sobre a renda disponível dos trabalhadores mais qualificados, $\beta_{h}$, alíquotas sobre os salários e lucros, $\tau_{W}$ e $\tau_{\pi}$, o parâmetro do investimento sensível a taxa de lucro, $\gamma_{1}$, e a distribuição de salários, $\psi_{L}$, como a Tabela 4 apresenta. Cabe destacar que as mudanças necessárias para tornar a economia profit-led foram consideravelmente significativas.

Por fim, a Tabela 5 exibe os valores iniciais normalizados de ambos os regimes de demanda. Estes valores são diferentes entre os regimes de demanda devido às mudanças nas variáveis exógenas. É por isso que por um lado, a utilização de capacidade é maior no regime wage-led, assim como o crescimento do estoque de capital, a riqueza e títulos públicos dos capitalistas, pois a renda disponível desta classe é mais elevada relativamente, devido à menor tributação dos lucros ou à menor sensibilidade do investimento à taxa de lucros. Por outro lado, dado que numa economia profit-led a tributação dos salários assim como a igualdade dos mesmos é menor, a riqueza e títulos públicos dos trabalhadores mais qualificados é maior. 
Tabela 3 - Parâmetros Exógenos

\begin{tabular}{|l|l|l|}
\hline & Wage-led & Profit-Led \\
$\omega_{t}$ & $-0,02$ & $-0,02$ \\
$\tau_{W, t}$ & 0,2 & 0,05 \\
$\tau_{\pi, t}$ & 0,1 & 0,35 \\
$\tau_{B, t}$ & 0,05 & 0,05 \\
$\tau_{V, t}$ & 0,01 & 0,01 \\
$\beta_{h, t}$ & 0,9 & 0,78 \\
$\beta_{c, t}$ & 0,7 & 0,7 \\
$\theta_{h, t}$ & 0,06 & 0,06 \\
$\theta_{c, t}$ & 0,04 & 0,04 \\
$\gamma_{0, t}$ & 0,0005 & 0,0005 \\
$\gamma_{1, t}$ & 0,001 & 0,05 \\
$\gamma_{2, t}$ & 0,18 & 0,18 \\
$r_{t}$ & 0,04 & 0,04 \\
$\psi_{W, t}$ & 0,4 & 0,4 \\
$\psi_{L, t}$ & 0,6 & 0,1 \\
$\xi$ & 0,037 & 0,037 \\
$\lambda 1, h, t$ & 0,6 & 0,6 \\
$\lambda 2, h, t$ & 0,6 & 0,6 \\
$\lambda 3, h, t$ & 0,1 & 0,1 \\
$\lambda 1, c, t$ & 0,8 & 0,8 \\
$\lambda 2, c, t$ & 0,8 & 0,8 \\
$\lambda 3, c, t$ & 0,1 & 0,1 \\
\hline
\end{tabular}

Tabela 4 - Valores Iniciais

\begin{tabular}{|l|l|l|}
\hline & Wage-led & Profit-Led \\
$u_{t}$ & 0,8212 & 0,6607 \\
$b_{h, t}$ & 0,028 & 0,158 \\
$b_{c, t}$ & 0,52 & 0,225 \\
$v_{h, t}$ & 0,053 & 0,029 \\
$v_{c, t}$ & 0,65 & 0,28 \\
$g_{k, t}$ & 0,022 & 0,018 \\
\hline
\end{tabular}

\subsection{Simulações}

Nesta seção são simulados e analisados choques nas variáveis exógenas comportamentais, distributivas e de política econômica em economias wage-led. Esse regime de demanda foi escolhido porque os valores iniciais da calibragem foram pensados nessa economia. Contudo, nos choques em que os efeitos no longo prazo forem divergentes, a análise da economia profit-led é feita mais detalhadamente.

Além disso, nas análises de cada variável, além da exposição aprofundada da dinâmica que os choques provocaram, são adicionadas duas seções i) comparações entre os regimes de demanda e ii) robustez. A primeira mostra a diferença das intensidades dos 
efeitos de longo prazo entre os dois regimes de demanda. Dessa forma, a despeito das dinâmicas e resultados serem similares, é possível entender e analisar como os parâmetros que determinam o regime de demanda afetam os valores finais nos respectivos regimes de demanda. A segunda distingue como alguns parâmetros iniciais podem afetar os resultados apresentados. Assim, são propostas, a partir do entendimento dos motivos que levaram a economia ao longo prazo, alterações de parâmetros de forma a mostrar o grau de robustez dos efeitos.

\subsubsection{Choques em Variáveis Comportamentais}

\subsubsection{Propensão a Consumir dos Trabalhadores Mais Qualificados sobre a Renda Disponível}

A Figura 1 mostra que um aumento permanente de 5\% na propensão a consumir sobre a renda disponível dos trabalhadores mais qualificados, $\beta_{h}$, tem um impacto positivo na utilização de curto prazo, como visto no capítulo anterior. Tal resultado é consequência do maior consumo dos trabalhadores mais qualificados sobre a renda disponível. No longo prazo, contudo, o efeito é negativo sobre utilização de capacidade.

Figura 1 - Efeito do aumento de $5 \%$ na propensão a consumir sobre a renda disponível dos trabalhadores mais qualificados $\left(\beta_{h}\right)$ na utilização $\left(u^{*}\right)$ e na proporção da riqueza dos trabalhadores mais qualificados na riqueza financeira total $\left(\varphi_{V}\right)$

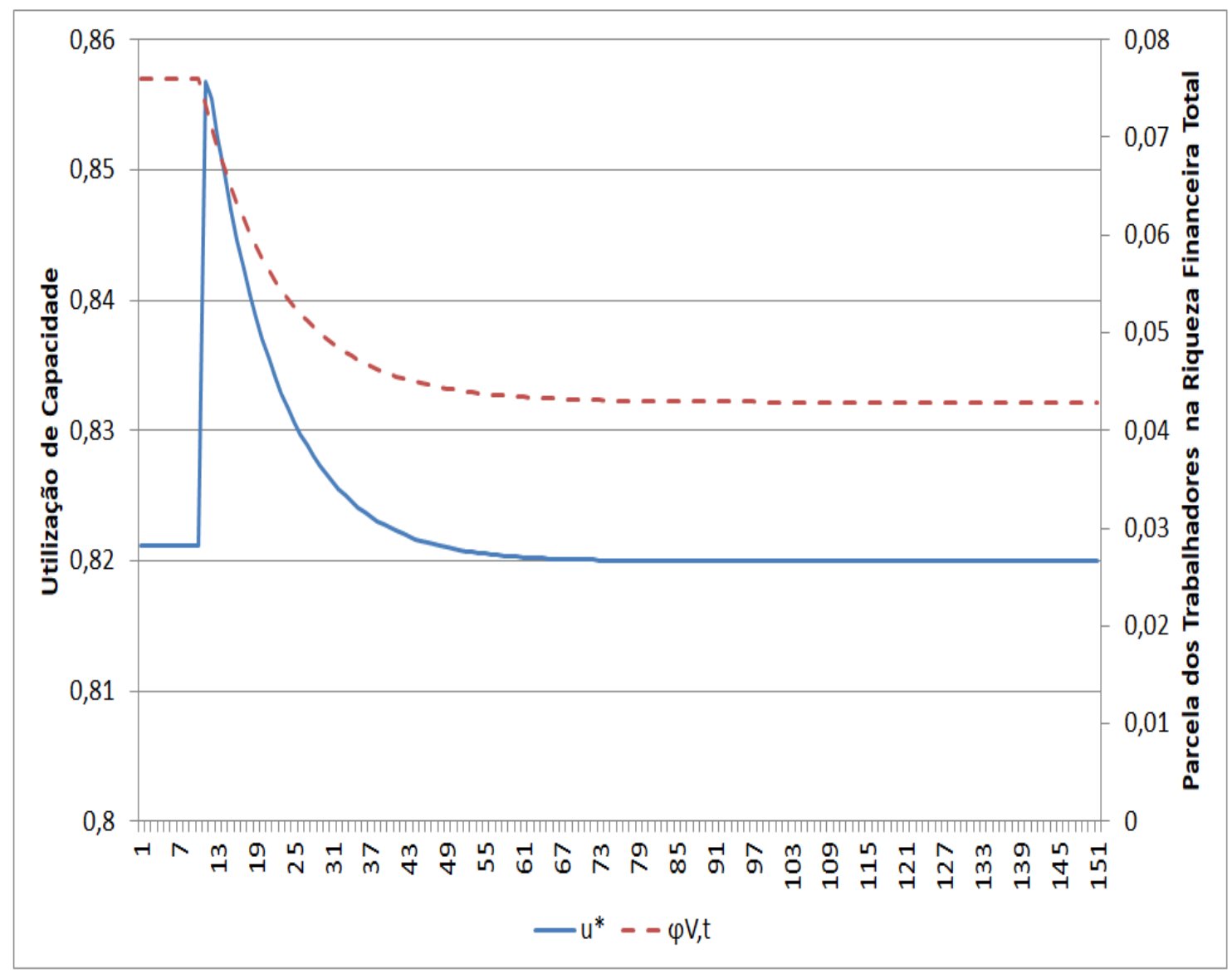


Esse efeito é consequência da menor poupança dos trabalhadores mais qualificados, que leva a uma queda da riqueza desta classe em proporção do estoque de capital, como pode ser visto na Figura 3. Repare que o aumento da renda da economia eleva o crescimento da riqueza dos capitalistas no curto prazo. Contudo, como a Figura 2 revela, o efeito composição dos gastos derivados da riqueza é negativo, ou seja, a queda do consumo sobre riqueza dos trabalhadores em relação ao estoque de capital é mais relevante do que o aumento do consumo sobre a riqueza dos capitalistas em relação ao estoque de capital, reduzindo a fonte de demanda proveniente dos estoques. Esta queda associada a um modesto aumento da renda financeira acarreta numa queda do crescimento do produto, ainda que permaneça superior aos períodos anteriores do choque. Tal redução na renda diminui ainda mais a ampliação da riqueza das famílias puxando para baixo a utilização, o que lava a um circulo vicioso.

Já o crescimento do estoque de capital reage positivamente ao aumento da utilização de capacidade no período do choque. Contudo, após a utilização atingir o seu ápice, a ampliação do capital passa a ocorrer a taxas cada vez menores, ainda que superiores aos períodos anteriores ao aumento na propensão a consumir dos trabalhadores mais qualificados. Além disso, como o investimento depende não apenas da demanda, mas também do estoque de capital do período anterior, o crescimento do estoque de capital é sempre maior do que o do produto. Dessa forma, a utilização continua a cair até o ponto em que se iguala ao observado no período anterior ao choque. A partir desse ponto, o próprio crescimento do estoque de capital passa a ser inferior ao dos períodos iniciais. Apesar disso, o produto continua a crescer mais lentamente que o capital físico, levando a uma utilização ainda menor. Assim, o efeito dinâmico da riqueza é tão grande que retira o paradoxo da poupança no longo prazo em um modelo que é liderado pela demanda.

Dado que o aumento na propensão a consumir dos trabalhadores mais qualificados reduz a capacidade dos trabalhadores mais qualificados de pouparem, os capitalistas passam a deter uma maior parcela da riqueza financeira, como a Figura 1 mostra. Por fim, a Figura 4 introduz uma nova variável, a parcela dos trabalhadores na repartição líquida da renda, $\varphi_{D L}$ que busca compreender o conflito distributivo da renda dos trabalhadores, mais e menos qualificados juntos, e dos capitalistas após o recebimento da renda financeira e do pagamento dos impostos.

$$
\psi_{D L, t}=\frac{Y_{D l, t}+Y_{D h, t}}{Y_{D l, t}+Y_{D h, t}+Y_{D c, t}}
$$

A parcela dos trabalhadores na repartição líquida de renda é elevada no curto prazo, pois a maior utilização tem um impacto mais relevante na renda dos trabalhadores do que na renda dos capitalistas. Contudo, no longo prazo, a composição da renda financeira, $\psi_{B}$, reduz-se, i.e, os capitalistas passam a deter uma maior proporção dos títulos 
Figura 2 - Efeito do aumento de $5 \%$ na propensão a consumir sobre a renda disponível dos trabalhadores mais qualificados $\left(\beta_{h}\right)$ nas fontes de determinação da demanda normalizadas)

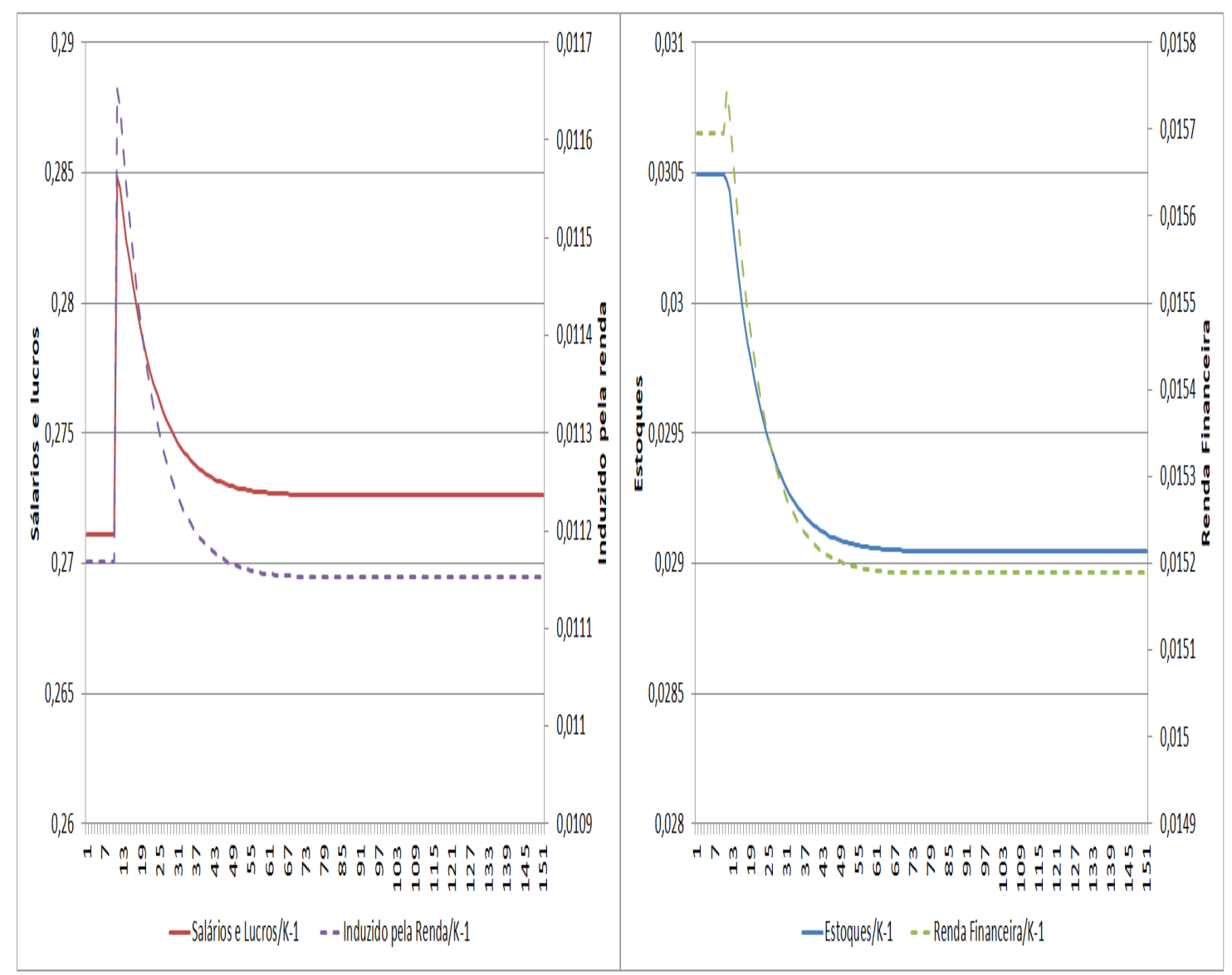

públicos. A renda dos trabalhadores cai relativamente à renda dos capitalistas.

Assim, é possível explicitar a correlação e a causalidade entre os efeitos sobre parcela dos trabalhadores na repartição líquida da renda e sobre proporção da riqueza dos trabalhadores mais qualificados na riqueza financeira total. No período do choque, a parcela dos trabalhadores na repartição da renda líquida se eleva enquanto que a proporção desta classe na distribuição de riqueza permanece estável. Ao contrário da intuição inicial, essa elevação da repartição de renda em prol dos trabalhadores não aumenta a parcela da riqueza dos trabalhadores, como o que ocorre é uma redução na proporção da riqueza desta classe na riqueza financeira total. E esta redução acarreta uma queda na parcela dos trabalhadores na repartição da renda líquida.

\section{Comparações entre os Regimes de Demanda}

O impacto do aumento da propensão a consumir sobre a renda disponível, no curto prazo, é mais intenso quando o regime é profit-led. Isto ocorre porque, nesse regime de demanda, os títulos públicos dos trabalhadores mais qualificados é maior, proporcionando 
Figura 3 - Efeito do aumento de $5 \%$ na propensão a consumir sobre a renda disponível dos trabalhadores mais qualificados $\left(\beta_{h}\right)$ na riqueza financeira dos trabalhadores normalizada $\left(v_{h}\right)$ na riqueza financeira dos capitalistas normalizada $\left(v_{c}\right)$ e no crescimento do estoque de capital $\left(g_{k}\right)$

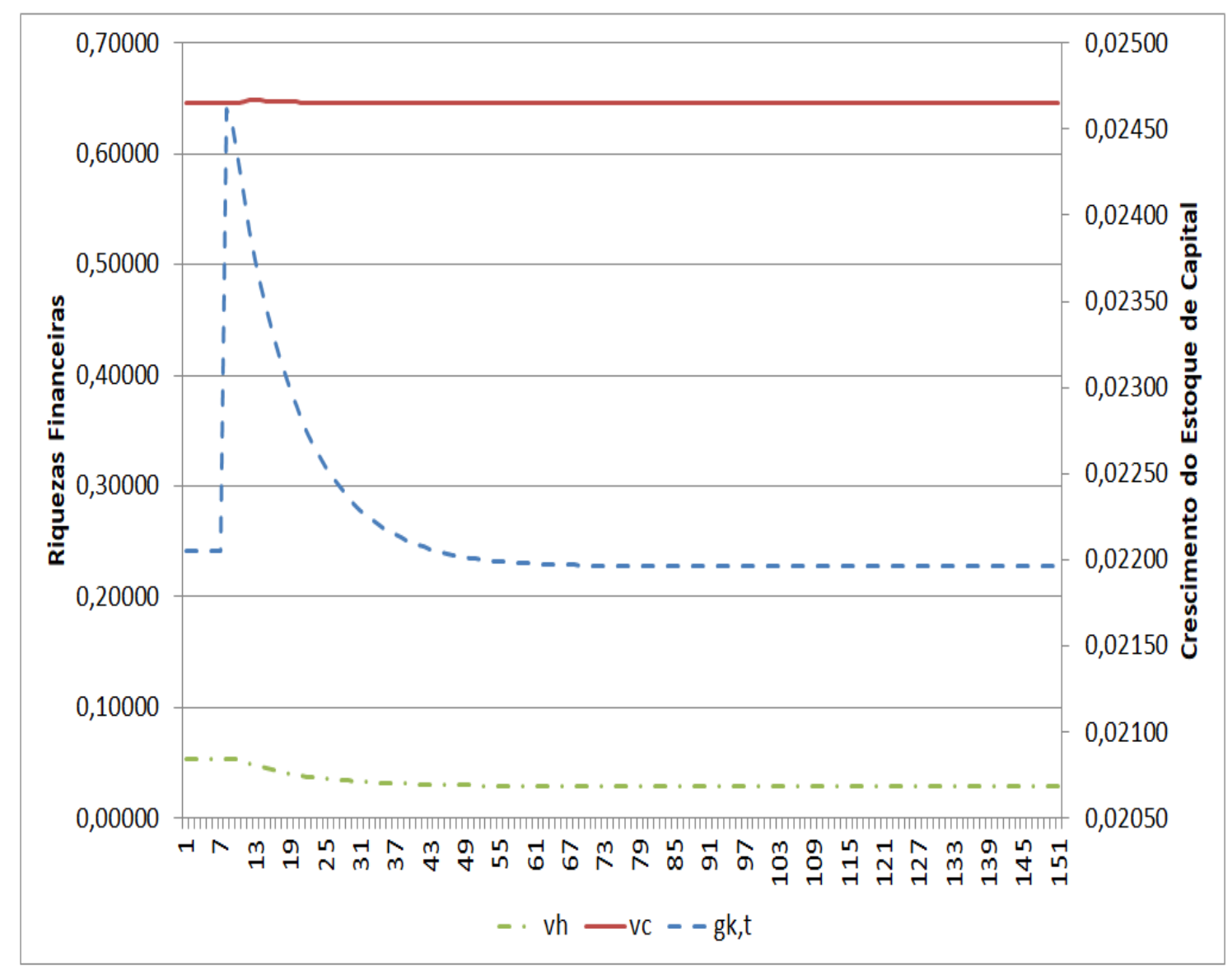

uma maior renda financeira. Além disso, como a tributação e a igualdade de salários são reduzidas, a renda disponível do trabalhador mais qualificado é mais elevada, intensificando o consumo.

A despeito da riqueza dos trabalhadores mais qualificados relativa ao estoque de capital ter uma queda mais significativa no regime wage-led e do aumento da riqueza dos capitalistas relativa ao estoque de capital ser superior no regime profit-led, a queda da fonte de demanda derivada dos estoques no regime profit-led é consideravelmente mais elevada. Isso ocorre, por um lado, porque a riqueza dos trabalhadores é pouco significativa no primeiro regime. Por outro lado, no segundo regime, a riqueza dos capitalistas é menos importante. Assim, a elevação da riqueza dos capitalistas impacta menos o consumo. Dado que é o processo nos estoques que causa a dinâmica de transição, a utilização de capacidade no longo prazo na economia profit-led sofre um efeito negativo maior do que a do caso wage-led.

Note ainda que, por um lado, o maior aumento no produto de curto prazo na 
Figura 4 - Efeito do aumento de $5 \%$ na propensão a consumir sobre a renda disponível dos trabalhadores mais qualificados $\left.\left(\beta_{h}\right)\right)$ na parcela dos trabalhadores na repartição líquida da renda $\left(\varphi_{D L}\right)$ e na taxa de lucros $(\sigma)$

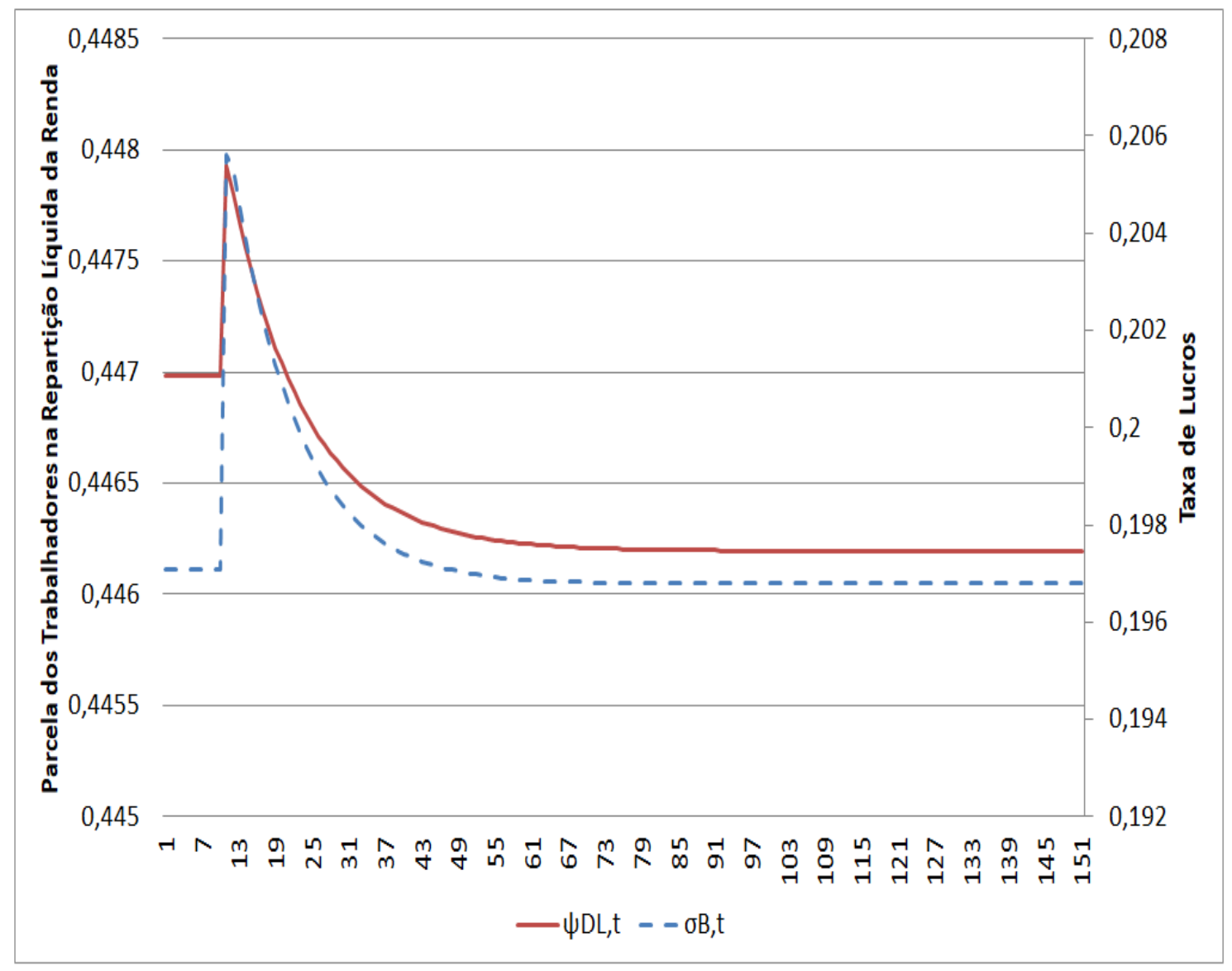

economia profit-led possibilita que os trabalhadores mais qualificados elevem mais a sua renda disponível, contrabalanceando relativamente o aumento da sua propensão a poupar, fazendo com que a queda da riqueza em proporção ao estoque de capital seja menor nesse regime de demanda (3,4\% no regime wage-led contra $0,04 \%$ quando for profit-led). Por outro lado, por mais que o aumento do produto também eleve a renda disponível dos capitalistas, a taxa sobre os lucros e o parâmetro do investimento induzido pela taxa de lucros sejam consideravelmente superiores nesse regime, a acumulação de riqueza pelos capitalistas tem um aumento mais baixo no caso profit-led (0,03\% contra 0,23\%). É por esta razão que o efeito negativo na parcela da riqueza dos trabalhadores na riqueza financeira total é menor neste regime $(10,4 \%)$ do que no caso wage-led (43,5\%).

\section{Robustez}

Como apresentado anteriormente, é o efeito riqueza que guia a dinâmica de longo prazo após o aumento da propensão a consumir sobre a renda disponível dos trabalhadores mais qualificados. Além disso, é o efeito negativo da dinâmica da riqueza dos trabalhadores mais qualificados superior ao efeito positivo da trajetória da riqueza dos capitalistas 
que faz com que a utilização de capacidade torne-se inferior no longo prazo. Assim, os parâmetros que são alterados para tentar avalizar os resultados são as propensões a consumir, assim como os impostos. Tais mudanças, ao modificar a capacidade de poupança das classes, podem inverter a relação entre a riqueza dos trabalhadores mais qualificados e a riqueza dos capitalista no efeito de longo prazo.

Elevações nos impostos dos trabalhadores sobre salários e sobre riqueza, assim como na propensão a consumir sobre a riqueza dos trabalhadores, não são capazes de alterar os resultados de longo prazo. Com relação aos capitalistas, a queda nos tributos sobre os lucros e sobre a riqueza também não modificam os resultados.

Contudo, numa economia wage-led, a redução na propensão a consumir sobre a riqueza dos capitalistas para 0,022 (queda de 45\%) é capaz de manter o paradoxo da poupança mesmo no longo prazo. Para entender é preciso voltar aos quatro canais pelos quais a riqueza afeta o produto que foram apresentadas na introdução deste capítulo. Inicialmente, a queda na propensão a consumir sobre a riqueza dos capitalistas faz com que os capitalistas reduzam o seu consumo sobre a riqueza, elevando a sua poupança. Destarte, no longo prazo, os capitalistas têm uma riqueza mais elevada do que na situação analisada anteriormente. Ainda assim, o efeito no consumo sobre a riqueza dos capitalistas é negativo. Entretanto, a riqueza eleva-se e os capitalistas passam a deter mais títulos públicos. Consequentemente, o consumo sobre a renda financeira e o gasto do governo se elevam. Assim, a soma dos efeitos faz com que a utilização de capacidade torne-se levemente superior ${ }^{5}$ após o choque na propensão a consumir sobre a renda dos trabalhadores mais qualificados.

Na economia profit-led o mesmo resultado pode ser obtido. Contudo, como mostrado anteriormente, os efeitos nessa economia são mais intensos, o que evidencia a maior diferença entre os efeitos da dinâmica entre as riquezas. Dessa forma, apenas uma queda na propensão sobre a riqueza dos capitalistas para 0,001 (queda de 98\%) permitiria validar o paradoxo da poupança no longo prazo.

\subsubsection{Propensão a Consumir dos Capitalistas sobre a Renda Disponível}

De acordo com a Figura 5, a elevação permanente de 5\% na propensão a consumir dos capitalistas sobre a renda disponível, $\beta_{c}$, tem um comportamento na utilização de capacidade muito similar do observado no aumento da propensão a consumir dos trabalhadores mais qualificados, $\beta_{h}$. Há uma ampliação no nível de utilização no curto prazo, mas no longo prazo esta variável torna-se inferior aos períodos anteriores ao choque. A justificativa do efeito de longo prazo é simétrica à observada no choque da propensão a consumir dos trabalhadores mais qualificados sobre a renda disponível. A elevação da

5 A propensão a consumir sobre a riqueza dos capitalistas igual a zero faria com que a utilização fosse $0,6 \%$ superior. 
propensão a consumir dos capitalistas sobre a renda disponível reduz a capacidade desta classe acumular poupança. Assim, a sua riqueza em proporção do estoque de capital tende a diminuir, reduzindo todas as quatro formas que este estoque impacta o produto, como a Figura 6 mostra.

Figura 5 - Efeito do aumento de $5 \%$ na propensão a consumir sobre a renda disponível dos capitalistas $\left(\beta_{c}\right)$ na utilização $\left(u^{*}\right)$ e na proporção da riqueza dos trabalhadores mais qualificados na riqueza financeira total $\left(\varphi_{V}\right)$

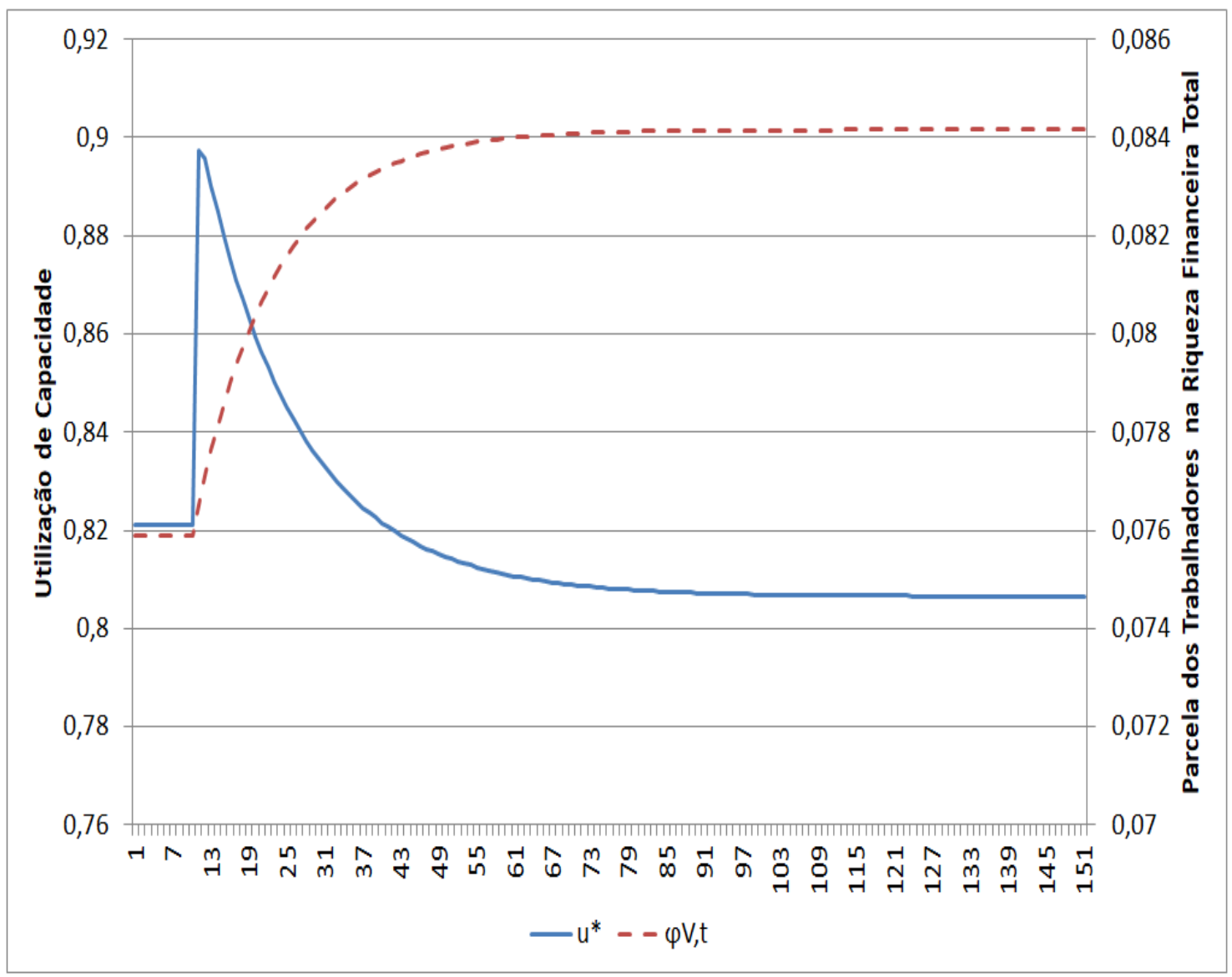

Já a proporção da riqueza financeira que é detida pelos trabalhadores mais qualificados eleva-se, uma vez que a poupança dos capitalistas reduz, diminuindo a sua capacidade de acumular riqueza. Além disso, no curto prazo, como no aumento da propensão a consumir dos trabalhadores mais qualificados, a elevação da propensão a consumir sobre a renda disponível dos capitalistas eleva a participação dos trabalhadores na repartição líquida da renda, uma vez que a utilização também se amplia. Diferentemente do aumento na propensão a consumir sobre a renda disponível dos trabalhadores mais qualificados anterior, no longo prazo, composição da renda financeira se eleva em prol dos trabalhadores, fazendo com que estes passem a deter uma maior proporção de títulos públicos. Dessa forma, há um efeito dinâmico na renda dos trabalhadores que supera a dos capitalistas, elevando ainda mais a parcela dos trabalhadores na repartição líquida da renda. 
Tanto no curto como no longo prazo, os efeitos da parcela dos trabalhadores na repartição líquida da renda e na proporção da riqueza dos trabalhadores mais qualificados na riqueza financeira total têm correlação positiva, sendo que no longo prazo, pode-se afirmar que há uma causalidade. É justamente a maior parcela da riqueza detida pelos trabalhadores que leva a uma maior apropriação da renda pelos trabalhadores. Entretanto, observa-se que no longo prazo essas duas variáveis tem correlação negativa com a utilização de capacidade.

Figura 6 - Efeito do aumento de $5 \%$ na propensão a consumir sobre a renda disponível dos capitalistas $\left(\beta_{c}\right)$ nas fontes de determinação da demanda normalizadas)

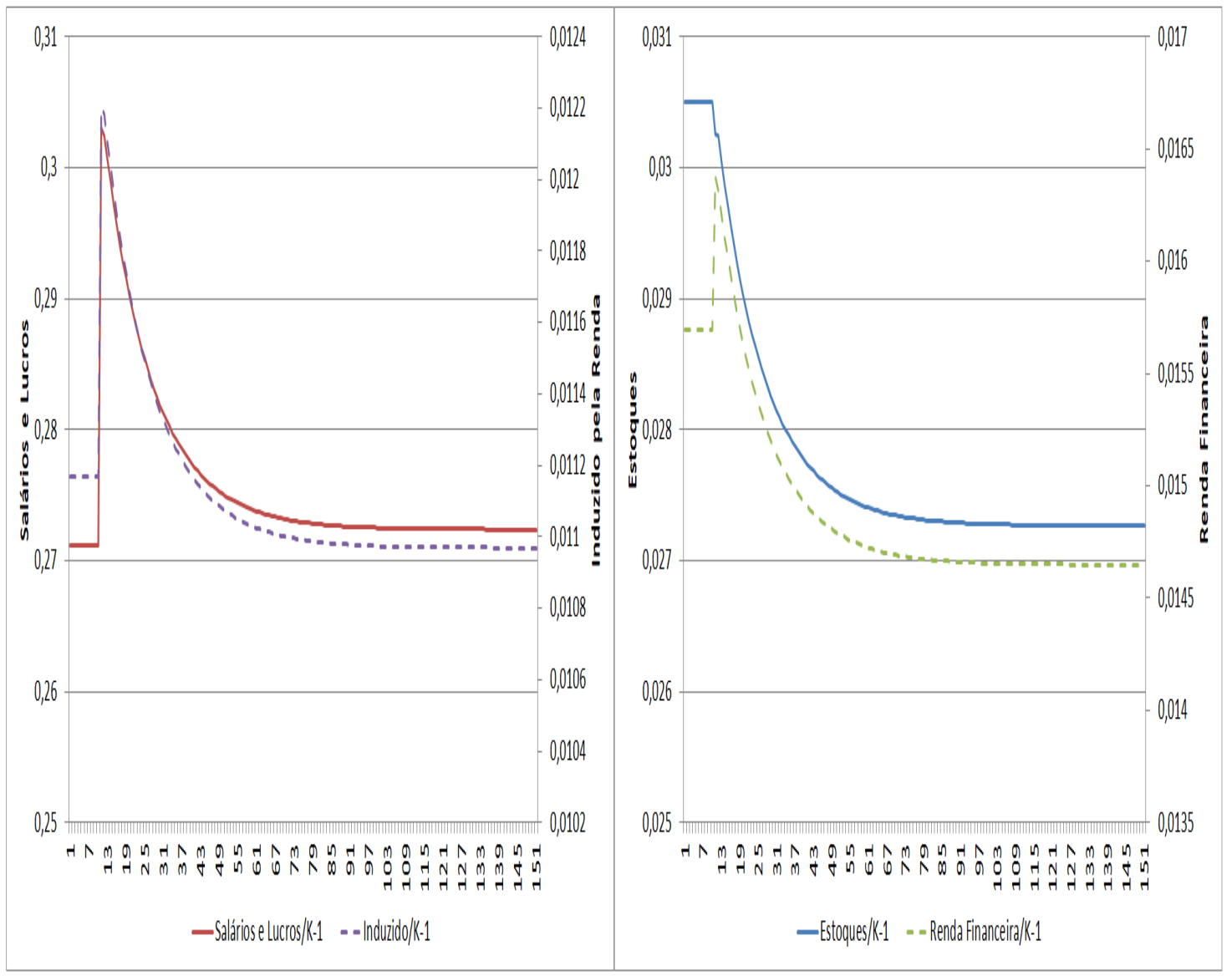

Por fim, cabe ressaltar a diferença na intensidade após os choques nas propensões a consumir sobre a renda disponível dos trabalhadores mais qualificados, $\beta_{h}$, e dos capitalistas, $\beta_{c}$, na utilização de capacidade. Repare que a fonte de demanda derivada dos estoques((3.3)) é negativamente relacionada com ambas variáveis. Contudo, a propensão a consumir sobre a renda disponível dos capitalistas também impacta o efeito do estoque de capital no produto, pois a renda disponível dos capitalistas é sensível ao capital físico, como pode ser visto em (2.10). Além disso, esta mesma relação pode ser observada na fonte de demanda derivada dos salários e lucros e na fonte de demanda induzida pela renda. O aumento da propensão a consumir sobre a renda disponível dos capitalistas reduz 
Figura 7 - Efeito do aumento de $5 \%$ na propensão a consumir sobre a renda disponível dos capitalistas $\left(\beta_{c}\right)$ na riqueza financeira dos trabalhadores normalizada $\left(v_{h}\right)$ na riqueza financeira dos capitalistas normalizada $\left(v_{c}\right)$ e no crescimento do estoque de capital $\left(g_{k, t}\right)$

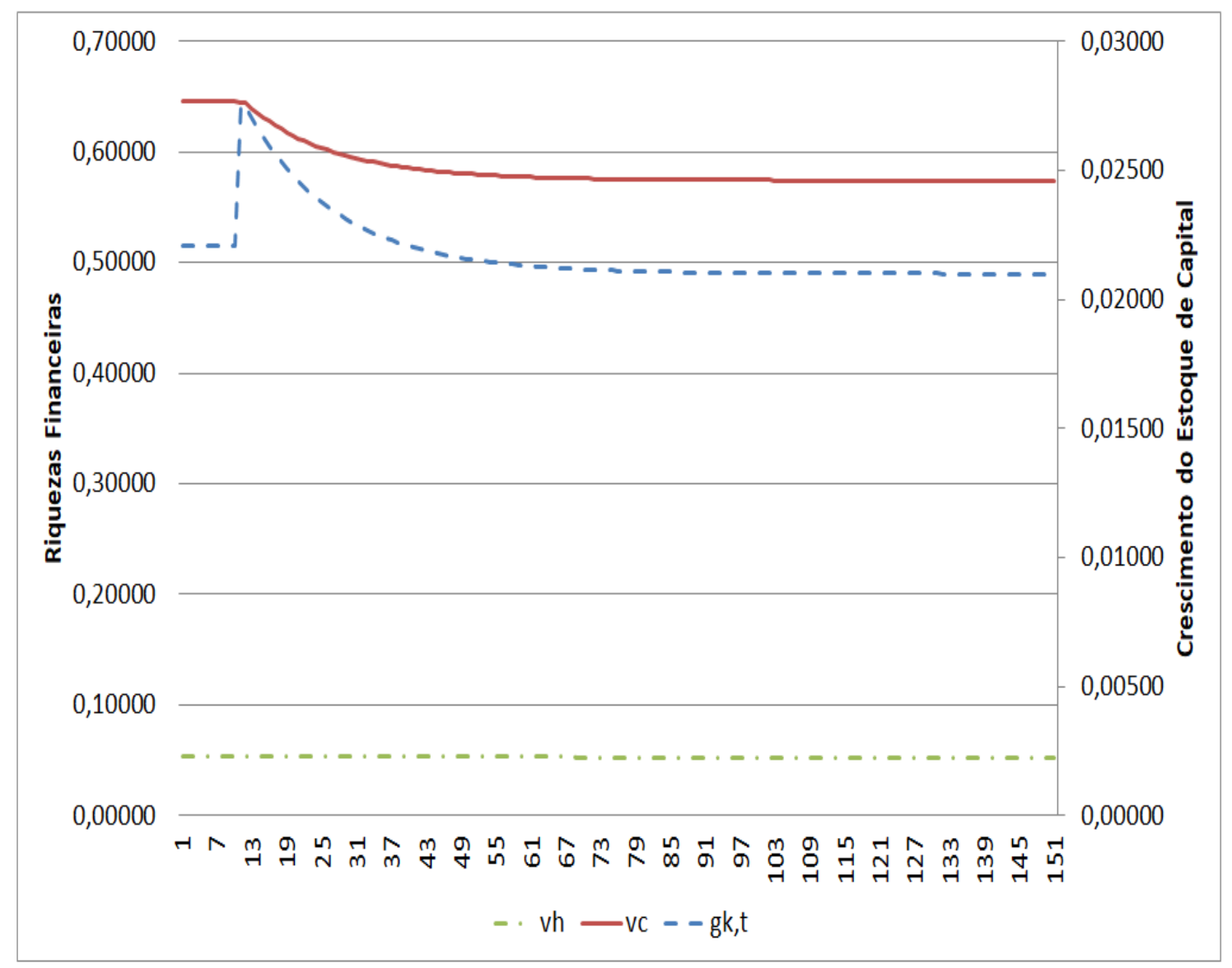

mais as fontes de determinação da demanda do que o aumento da propensão a consumir dos trabalhadores mais qualificados, explicando a maior queda na utilização.

\section{Comparação entre os Regimes de Demanda}

O aumento da propensão a consumir dos capitalistas sobre a renda disponível, ao contrário da elevação da propensão a consumir dos trabalhadores mais qualificados, tem um efeito de curto prazo mais elevado na economia wage-led. Isso ocorre porque nesse regime de demanda são os capitalistas que detém uma maior quantidade de títulos públicos em relação ao estoque de capital, proporcionando uma maior renda financeira. Além disso, como a taxa sobre os lucros e a propensão a investir sobre os lucros são menores, a renda disponível dos capitalistas é mais elevada, potencializando o consumo.

No longo prazo, a economia wage-led também sofre um efeito negativo superior ao da economia profit-led. Pela Figura 6, percebe-se que a fonte de demanda derivada dos estoques tem uma queda consideravelmente superior no regime wage-led (12,1\% contra $5,1 \%$ no regime profit-led), enquanto que fonte de demanda induzida pela renda tem uma 
Figura 8 - Efeito do aumento de $5 \%$ na propensão a consumir sobre a renda disponível dos capitalistas $\left(\beta_{c}\right)$ na parcela dos trabalhadores na repartição líquida da renda $\left(\varphi_{D L}\right) \mathrm{e}$ na taxa de lucros $(\sigma)$

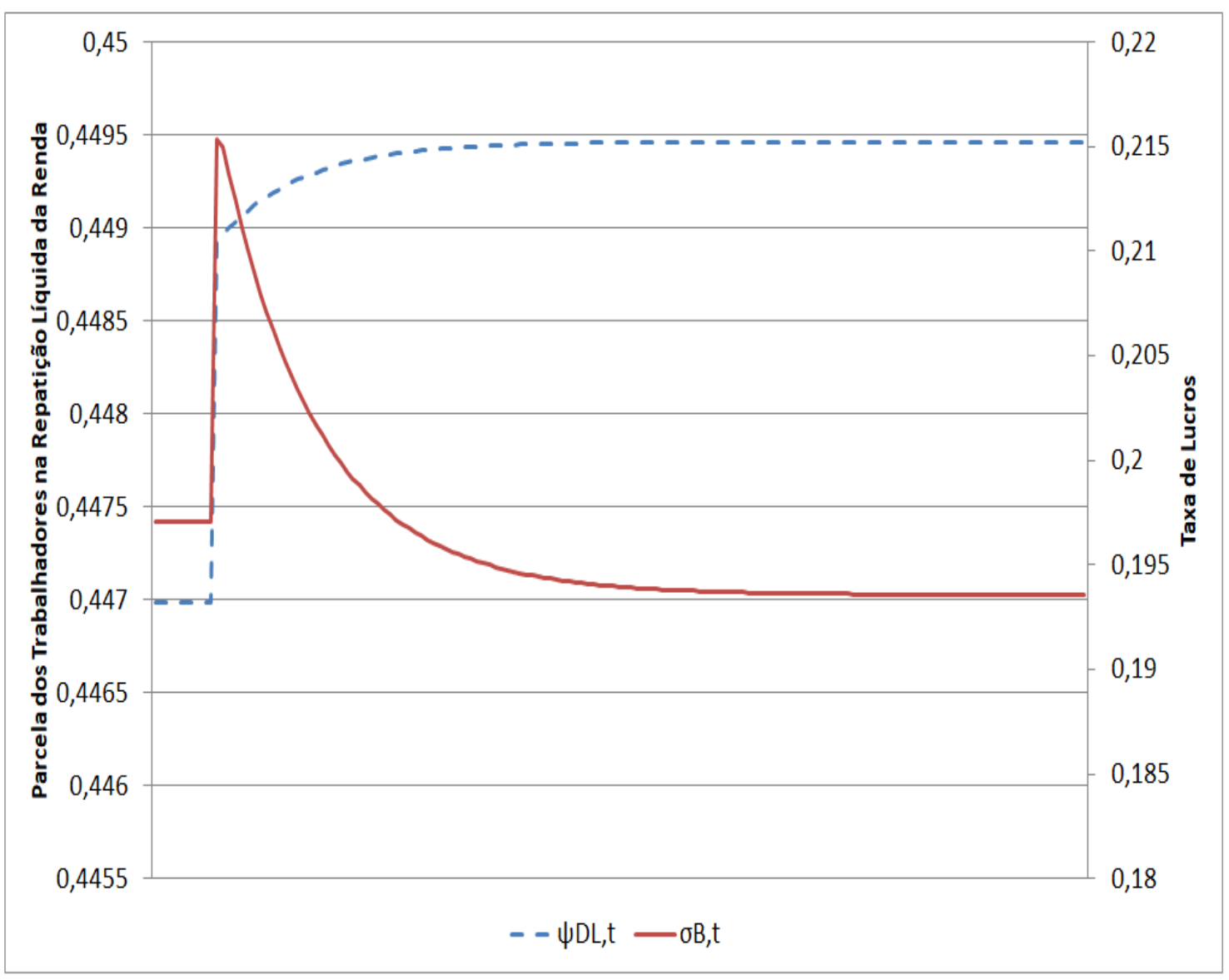

queda inferior nesse regime (2,1\% contra 19,8\%). Já a fonte de demanda derivada dos dos salários e lucros tem um leve aumento $(0,1 \%)$ contra uma queda no caso profit-led $(0,1 \%)$. O primeiro ocorre porque a riqueza dos capitalistas é maior no caso wage-led. Dessa forma, a queda da proporção entre a riqueza dos capitalistas e o estoque de capital, como pode ser observado na Figura 7, é mais relevante para a fonte de demanda derivada dos estoques. Assim, ainda que a fonte de demanda dos salários e lucros seja aproximadamente quatro vezes superior à fonte de demanda derivada dos estoques no produto, como o efeito na fonte dos salários e lucros é significantemente mais intenso, a queda na utilização também o será.

A riqueza dos capitalistas em proporção ao estoque de capital tem uma queda muito próxima nos dois regimes $(12,9 \%)$, enquanto que a redução na riqueza dos trabalhadores não qualificados em proporção ao estoque de capital é ligeiramente superior no regime wage-led $(0,7 \%$ contra $0,5 \%)$. O efeito positivo na distribuição de riqueza em prol dos trabalhadores, contudo, é mais significativo no regime wage-led (12,8\% contra $6,8 \%$ ) devido ao efeito composição. Nesse regime os capitalistas possuem uma parcela significativamente maior da riqueza (93\%), enquanto que no regime profit-led a riqueza 
é praticamente igualmente distribuída entre as classes. Dessa forma, a queda na riqueza dos capitalistas é mais sentida no regime wage-led do que no regime profit-led.

\section{Robustez}

O aumento da propensão a consumir sobre a renda disponível dos capitalistas é robusto em todos os resultados analisados anteriormente, tanto na economia wageled como profit-led. Nenhuma alteração de parâmetro é capaz de causar o paradoxo da poupança no longo prazo. Cabe destacar que isso não retira a importância da dinâmica da riqueza para a determinação do longo prazo. A diferença deste choque com relação ao observado no aumento na propensão a consumir sobre a renda disponível dos trabalhadores mais qualificados é que mesmo quando a propensão a consumir dos capitalistas sobre a riqueza cai para zero, o efeito que a ampliação da propensão a consumir dos capitalistas sobre a renda disponível é mais significativo na redução da sua riqueza em proporção do estoque de capital. Assim, a despeito do consumo dos capitalistas sobre a riqueza ser zero (supondo propensão a consumir sobre a riqueza igual a zero), a queda relativa no consumo sobre a renda financeira ou nos impostos sobre a riqueza e/ou sobre a renda financeira faz com que a utilização necessariamente caia.

\subsubsection{Propensão a Consumir dos Trabalhadores Mais Qualificados sobre a Riqueza}

Como pode ser visto na Figura 9, o comportamento da utilização e da proporção da riqueza dos trabalhadores mais qualificados na distribuição de riqueza após um aumento permanente de $10 \%$ na propensão a consumir dos trabalhadores sobre a riqueza, $\theta_{h}$, é exatamente igual aquele observado após a elevação da propensão a consumir sobre a renda disponível. A menor poupança dos trabalhadores mais qualificados reduz a sua capacidade de acumular riqueza, reduzindo a fonte de demanda derivada dos estoques no longo prazo. Assim, a utilização de capacidade, a despeito de uma elevação no curto prazo, torna-se inferior à que ocorria antes do choque.

A diferença entre as alterações nas propensões reside apenas na intensidade dos

efeitos. ${ }^{6}$ Repare que a proporção entre as propensões a consumir, $\frac{\beta_{h}}{\theta_{h}}$, é consideravelmente alta em ambos os regimes de demanda. Seria necessário que a riqueza dos trabalhadores mais qualificados fosse consideravelmente maior que a renda disponível a fim de que o aumento da propensão associada à riqueza tivesse um efeito maior. Visto que a riqueza dos trabalhadores mais qualificados é levemente superior a sua renda disponível (25\%), o efeito do aumento da propensão a consumir sobre a riqueza é significativamente menor.

6 Por um lado a propensão a consumir sobre a riqueza afeta a utilização em 0,01\%, a proporção da riqueza dos trabalhadores mais qualificados na distribuição de riqueza em financeira $3,3 \%$ e a parcela da renda dos trabalhadores na repartição líquida da renda em $0,02 \%$. Por outro lado, a propensão a consumir sobre a renda impacta a utilização em $0,15 \%$, a proporção da riqueza dos trabalhadores mais qualificados na distribuição de riqueza financeira em $43,5 \%$ e a parcela da renda dos trabalhadores 
Figura 9 - Efeito do aumento de $10 \%$ na propensão a consumir sobre a riqueza dos trabalhadores mais qualificados $\left(\theta_{h}\right)$ na utilização $\left(u^{*}\right)$ e na proporção da riqueza dos trabalhadores mais qualificados na riqueza financeira toral $\left(\varphi_{V}\right)$

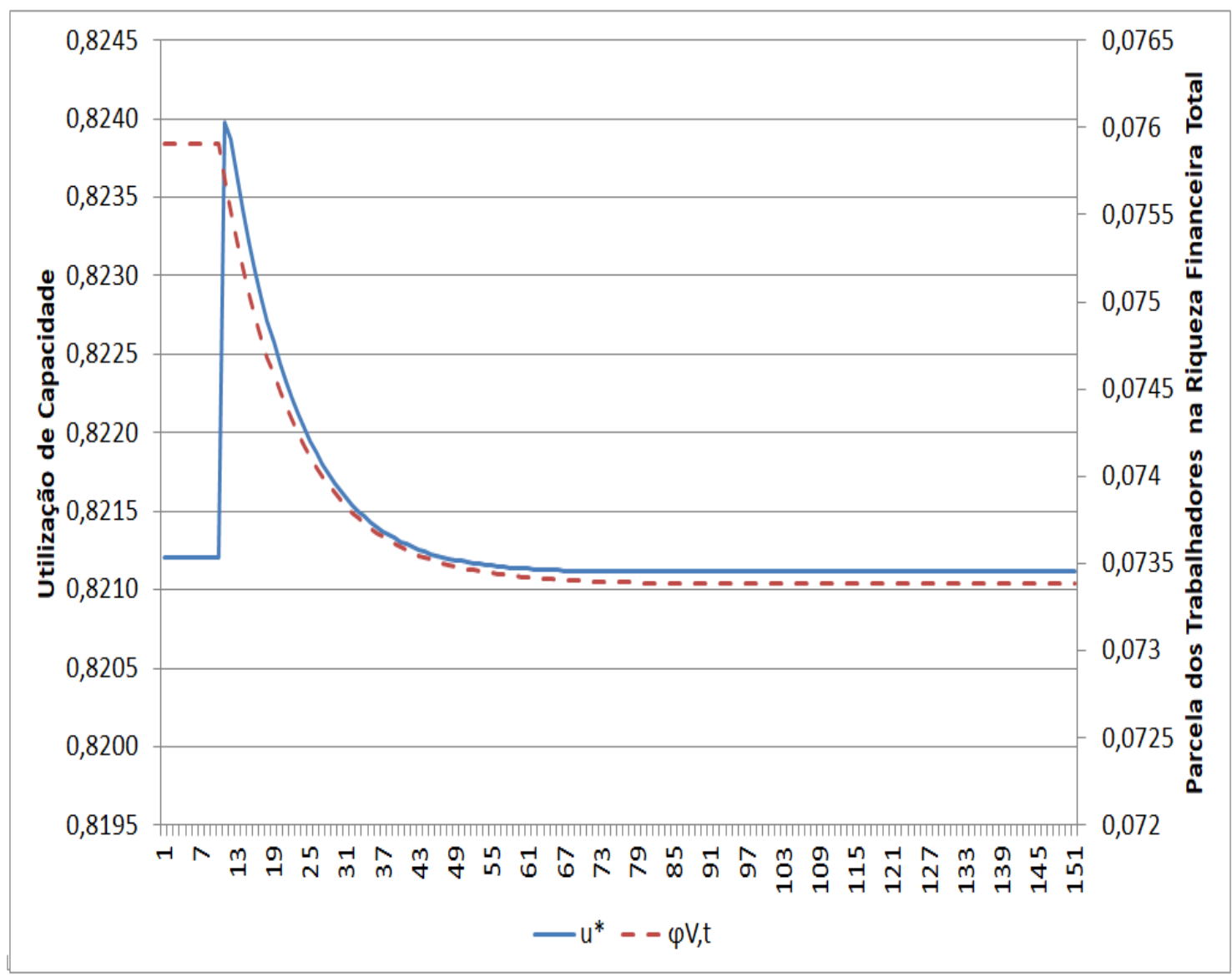

\section{Robustez}

Assim como no choque na propensão a consumir sobre a renda disponível dos trabalhadores, é o efeito dinâmico na riqueza que predomina no equilíbrio de longo prazo. Portanto, são necessários os mesmas alterações nos parâmetros que foram feitas anteriormente. Elevações nos impostos sobre salários e sobre a riqueza dos trabalhadores não são capazes de gerar o paradoxo da poupança no longo prazo. Nem mesmo a combinação destes choques com a elevação da propensão a consumir sobre a renda disponível dos trabalhadores e concomitante redução dos impostos sobre os lucros e riqueza dos capitalistas são capazes de proporcionar mudanças nos resultados obtidos anteriormente.

Contudo, na economia wage-led, a queda na propensão a consumir sobre a riqueza dos capitalistas para 0,022 é capaz de reestabelecer o paradoxo da poupança no longo prazo. Além disso, na economia profit-led, da mesma forma que no choque na propensão a consumir sobre a renda disponível, é preciso uma queda muito drástica na propensão a consumir sobre a riqueza dos capitalistas para ter o mesmo efeito. 
Figura 10 - Efeito do aumento de 5\% na propensão a consumir sobre a riqueza dos trabalhadores mais qualificados $\left.\left(\theta_{h}\right)\right)$ na parcela dos trabalhadores na repartição líquida da renda $\left(\varphi_{D L}\right)$ e na taxa de lucros $(\sigma)$

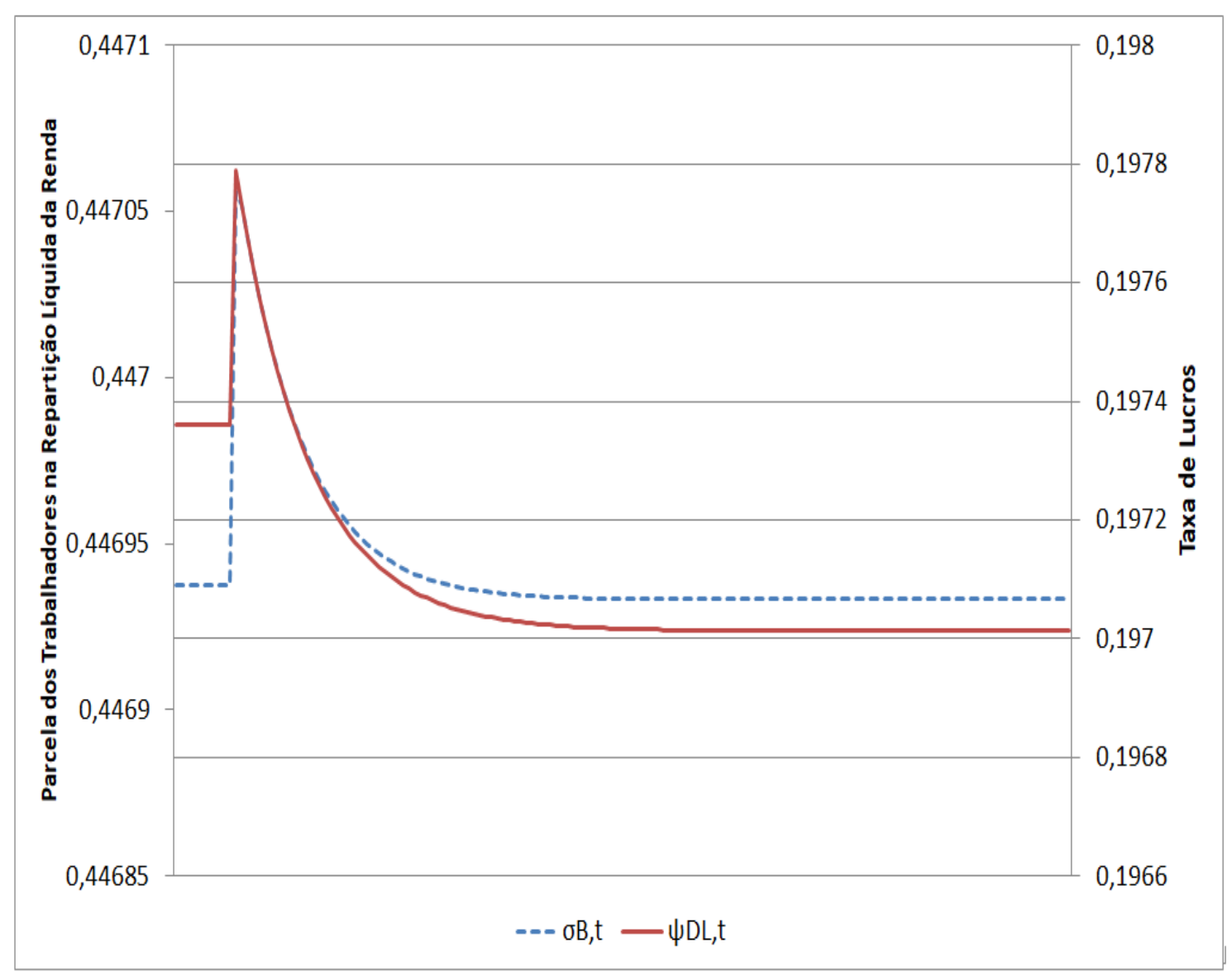

\subsubsection{Propensão a Consumir dos Capitalistas sobre a Riqueza}

Assim como a propensão a consumir dos trabalhadores mais qualificados sobre a riqueza tem o mesmo comportamento sobre as variáveis endógenas que a propensão a consumir dos trabalhadores mais qualificados sobre a renda disponível, a elevação permanente de $10 \%$ na propensão a consumir dos capitalistas sobre a riqueza possui o mesmo efeito que a sua propensão a consumir sobre a renda disponível. A redução na poupança dos capitalistas também reduz a sua capacidade de acumular riqueza, e portanto, a fonte derivada dos estoques de longo prazo se reduz.

Nesse caso, a proporção das intensidades entre os impactos das propensões a consumir dos capitalistas sobre a renda e da propensão a consumir sobre a riqueza também se verifica. O aumento da propensão a consumir sobre a riqueza dos capitalistas reduz a utilização em $0,5 \%$ e aumenta a parcela dos trabalhadores na riqueza e renda em 3,2\% e $0,17 \%$, respectivamente. Já o aumento da propensão a consumir sobre a renda disponível dos capitalistas diminui a utilização em 1,8\%, enquanto eleva as distribuições de riqueza e renda em prol dos trabalhadores em 10,8\% e 0,6\%, respectivamente. É impor- 
Figura 11 - Efeito do aumento de $10 \%$ na propensão a consumir sobre a riqueza dos capitalistas $\left(\theta_{c}\right)$ na utilização $\left(u^{*}\right)$ e na proporção da riqueza dos trabalhadores mais qualificados na distribuição de riqueza financeira $\left(\varphi_{V}\right)$

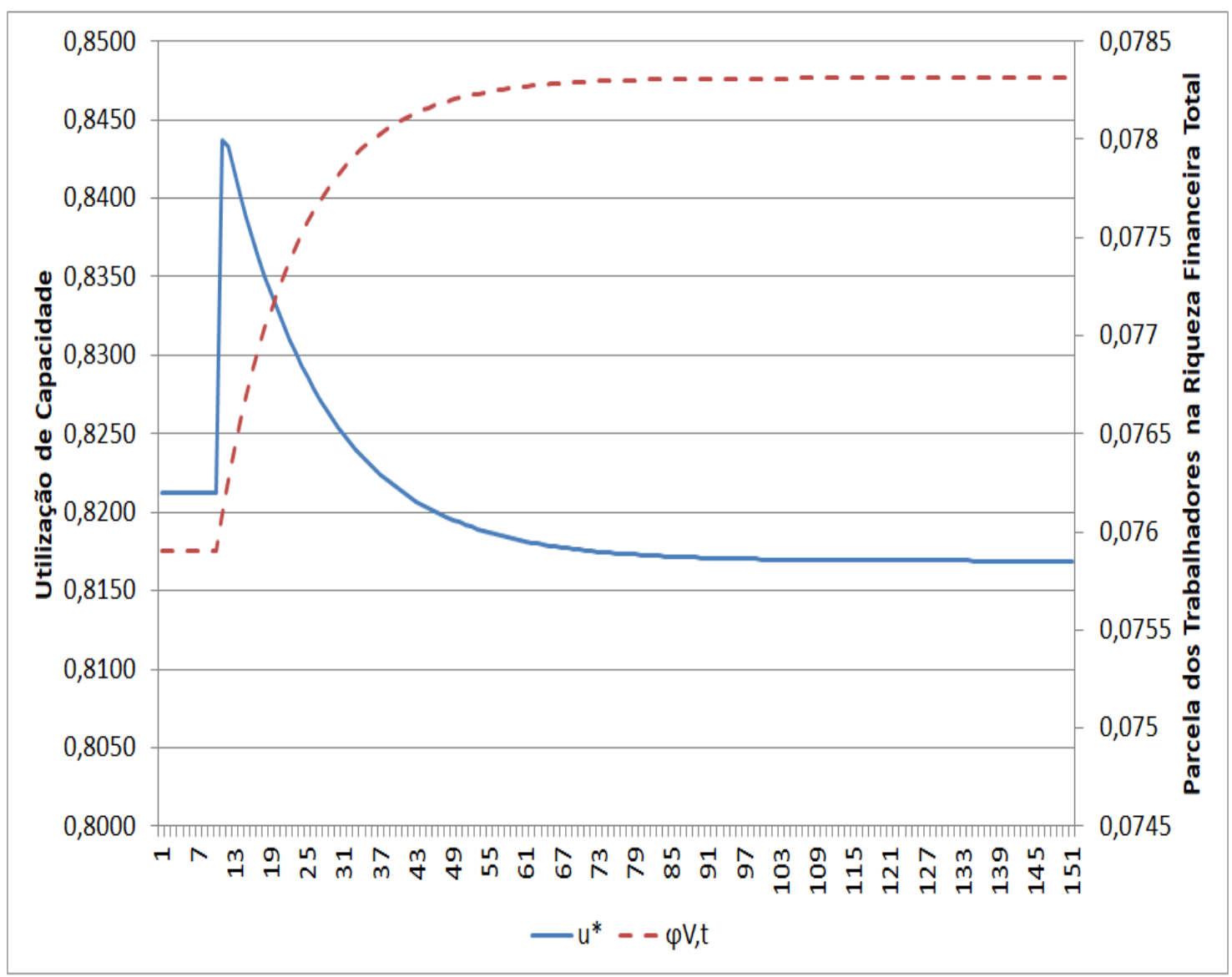

tante ressaltar que, ainda que a propensão sobre a renda tenha um efeito na utilização de capacidade quatro vezes superior que a propensão sobre a riqueza, a proporção dos impactos é consideravelmente menor do que aquela observada nos choques das variáveis comportamentais dos trabalhadores mais qualificados. Isso ocorre porque a riqueza dos capitalistas é bem superior à dos trabalhadores qualificados. Dessa forma, pode-se concluir que há uma importância para os resultados maior da propensão a consumir sobre a riqueza dos capitalistas.

\section{Robustez}

Assim como no choque na propensão a consumir sobre a renda disponível dos capitalistas, é possível garantir a robustez dos resultados independentemente de variações no parâmetros. 
Figura 12 - Efeito do aumento de $5 \%$ na propensão a consumir sobre a riqueza dos capitalistas $\left(\theta_{c}\right)$ na parcela dos trabalhadores na repartição líquida da renda $\left(\varphi_{D L}\right)$ e na taxa de lucros $(\sigma)$

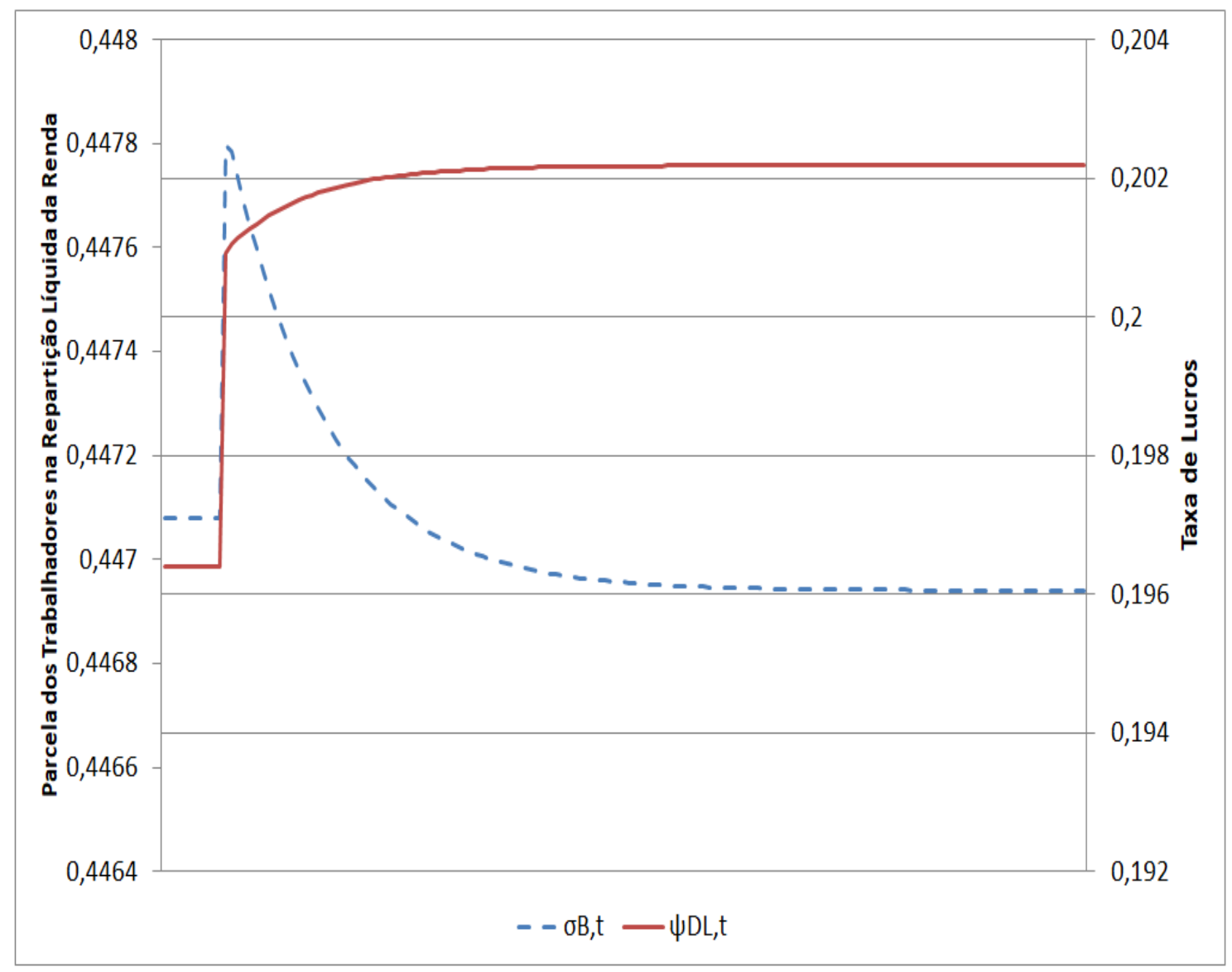

\subsubsection{Distribuição Funcional da Renda}

O aumento permanente de $10 \%$ na parcela de salários na renda, $\psi_{W}$, tem um efeito positivo na utilização numa economia wage-led e negativo quando a economia for profit-led, por construção. Além disso, a Figura 13 mostra que em ambos os regimes de demanda a utilização de longo prazo torna-se menor do que antes do choque, com uma queda superior no primeiro. Contudo, uma vez que a trajetória é ligeiramente diferente nos dois regimes, nessa seção ambos os regimes serão analisados.

Em uma economia wage-led, no período do choque, apenas a fonte de demanda derivada dos salários e lucros em proporção do estoque de capital se eleva. Esta corresponde a mais de $80 \%$ da utilização e, por isso, tal aumento alavanca a renda. No período seguinte, a fonte de demanda derivada dos estoques em proporção ao estoque de capital reduz, assim como a fonte de demanda derivada da renda financeira em proporção ao estoque de capital. Assim, a utilização de capacidade se reduz, ainda que continue mais elevada do que antes do choque. Isto acarreta em uma intensificação da redução, em relação ao estoque de capital, na fonte de demanda derivada dos estoques e na fonte da renda 
Figura 13 - Efeito do aumento de $10 \%$ na parcela de salários na renda, $\left(\psi_{W}\right)$, na utilização $\left(u^{*}\right)$ e na proporção da riqueza dos trabalhadores mais qualificados na riqueza financeira total $\left(\varphi_{V}\right)$

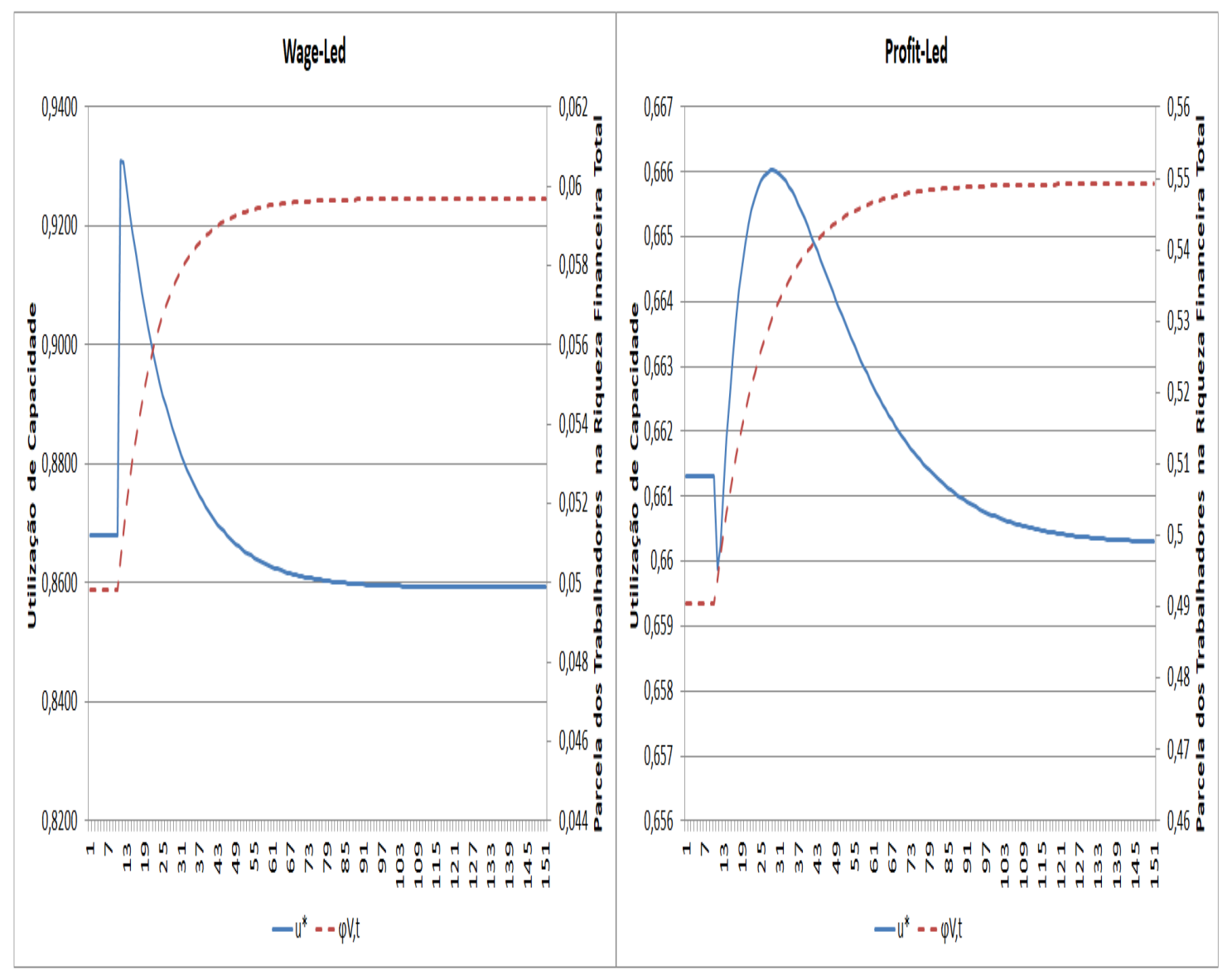

financeira ${ }^{7}$, que ocorre porque os capitalistas têm uma propensão a poupar mais elevada do que a dos trabalhadores mais qualificados. O aumento da parcela de salários na renda afeta justamente a classe que tem maior tendência a expandir a riqueza, e portanto o consumo a partir dela. Dessa forma, ainda que a riqueza dos trabalhadores aumente, o efeito redução da riqueza dos capitalistas em relação ao estoque de capital torna-se mais crucial do que a diferença entre as propensões a consumir.

No período do choque, o efeito no investimento é ambíguo, pois por um lado,

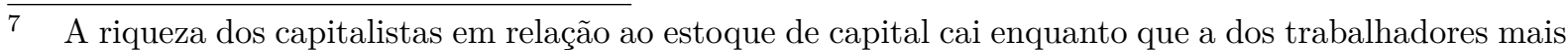
qualificados aumenta. Assim, o efeito na fonte de demanda dos estoques depende da composição do efeito no consumo das duas classes. É possível afirmar que o efeito de longo prazo independe da diferença entre as propensões a consumir sobre a riqueza. Suponha que essa propensão dos trabalhadores mais qualificados é suficientemente alta para que a fonte dos estoques na demanda em proporção ao estoque de capital se eleve. Ainda assim, como esse aumento é pouco significativo a utilização irá cair, dado que as outras fontes de demanda ou passam a acompanhar a própria utilização, como os salários e lucros ou continuem a cair como a renda financeira. Tal queda reduz a riqueza dos trabalhadores mais qualificados em e dos capitalistas em relação ao estoque de capital ao reduzir a renda disponível. O processo se retroalimenta fazendo com que a queda da fonte de demanda derivada dos estoques em proporção do estoque de capital torne-se inferior ao que era antes do choque. Portanto, pela Tabela 7, o efeito de longo prazo é negativo. 
Figura 14 - Efeito do aumento de $10 \%$ na parcela de salários na renda, $\left(\psi_{W}\right)$, nas fontes de determinação da demanda normalizadas)

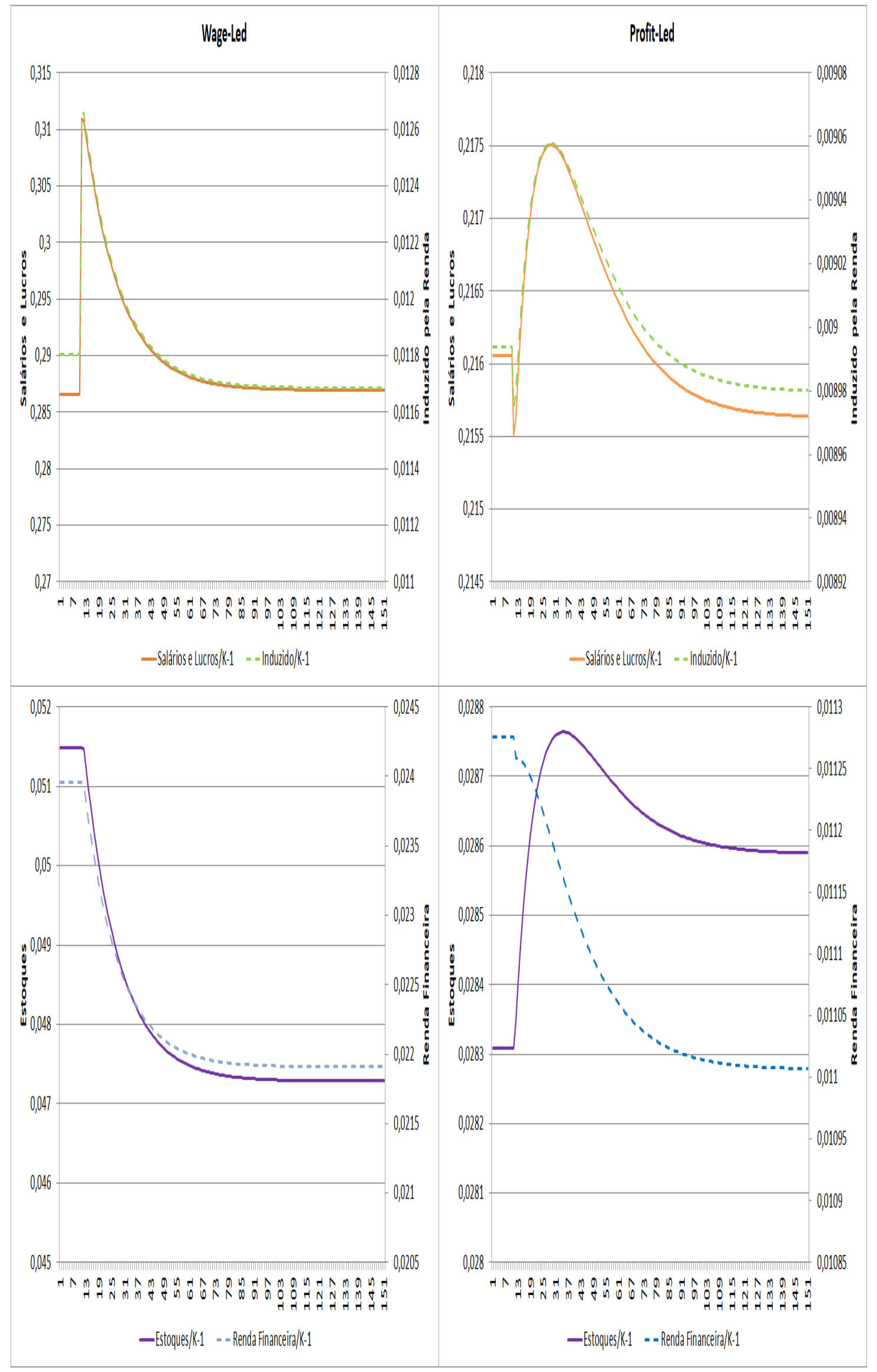


aumenta a demanda, mas por outro lado, reduz a taxa de lucros. O primeiro efeito é mais relevante do que o segundo ${ }^{8}$, expandindo o investimento. Entretanto, cabe lembrar que há uma defasagem entre o investimento e a formação do estoque de capital. Assim, o crescimento do capital permanece constante no período do choque, como a Figura 6 indica. Por essa razão, a utilização tem uma grande expansão no período do choque e uma leve queda no seguinte ${ }^{9}$, como a Figura 13 mostra. Quando a utilização se reduz, o crescimento do investimento também desacelera. Por (2.8), o investimento é impactado positivamente pelo estoque de capital do período anterior. Assim, a defasagem passa a atuar em favor do crescimento do estoque de capital, ou seja, este torna-se permanentemente superior ao crescimento do produto, até que ambos sejam iguais no longo prazo. Em função disso, a diferença entre o crescimento médio de ambos reduz-se a cada período. E quando são iguais, a utilização é exatamente a mesma que antes do choque. Por fim, cabe destacar que ainda que a utilização se torne mais baixa que antes do choque, há um significativo efeito no nível de produto durante muitos períodos.

A despeito da redução na utilização, na economia profit-led, ${ }^{10}$ no período do choque, esta torna-se bastante elevada nos períodos seguintes. A razão desta alteração é consequência do efeito significativo na fonte de demanda derivada dos estoques na utilização, compensando a queda da fonte de demanda derivada dos salários e lucros do período inicial. A fonte de demanda dos estoques tem esse comportamento porque a proporção da riqueza inicial pertencente aos trabalhadores nesse regime de demanda é maior. Assim, ainda que o crescimento da riqueza dos trabalhadores mais qualificados seja menor que na economia wage-led, como a Figura 15 apresenta, qualquer aumento na riqueza dessa classe tem um impacto muito maior no consumo. Assim como no caso wage-led, no longo prazo o efeito (negativo) na acumulação de riqueza dos capitalistas torna-se mais relevante, fazendo com que os estoques tenham uma queda ${ }^{11}$. Isto, associado ao efeito negativo no crescimento da renda financeira, leva a uma queda no crescimento do produto.

O crescimento do investimento, no período do choque é reduzido tanto pela queda da taxa de lucro como pela queda na demanda. Com o resultado do aumento do produto no período seguinte, o aumento da utilização impacta positivamente a formação de capital. Essa ampliação estabiliza quando a utilização está no seu auge ${ }^{12}$. A partir desse momento, o crescimento do estoque de capital passa a cair, mas, assim como no caso wage-led, o

$8 \quad \frac{\partial I_{t}}{\partial Y_{t}}=\left(\gamma_{1, t}\left(1-\psi_{W, t}\right)+\gamma_{2, t}\right) \frac{\partial Y_{t}}{\partial \psi_{W, t}}-\gamma_{1, t} Y_{t}=0,1806 \frac{\partial Y_{t}}{\partial \psi_{W, t}}-0,001 Y_{t}$

9 Lembre que o produto de plena capacidade é calculado utilizando o estoque de capital do período anterior.

10 Repare que essa economia é menos profit-led do que a outra é wage-led. Isto é, mudanças na distribuição funcional da renda impacta mais a utilização de curto prazo no regime de demanda wage-led do que no profit-led.

11 Note que a diferença na acumulação das duas classes é menor no caso profit-led do que no wage-led. Destarte, o efeito no longo prazo é menos intenso no primeiro.

12 Isso acontece quando a razão do crescimento médio do produto e do crescimento médio do estoque de capital é máxima 
crescimento médio do capital é sempre maior que o crescimento médio do produto. Desse modo, a utilização, no longo prazo, será menor que antes do choque.

Figura 15 - Efeito do aumento de $10 \%$ na parcela de salários na renda $\left(\psi_{W}\right)$ na riqueza financeira dos trabalhadores normalizada $\left(v_{h}\right)$ na riqueza financeira dos capitalistas normalizada $\left(v_{c}\right)$ e no crescimento do estoque de capital $\left(g_{k}\right)$

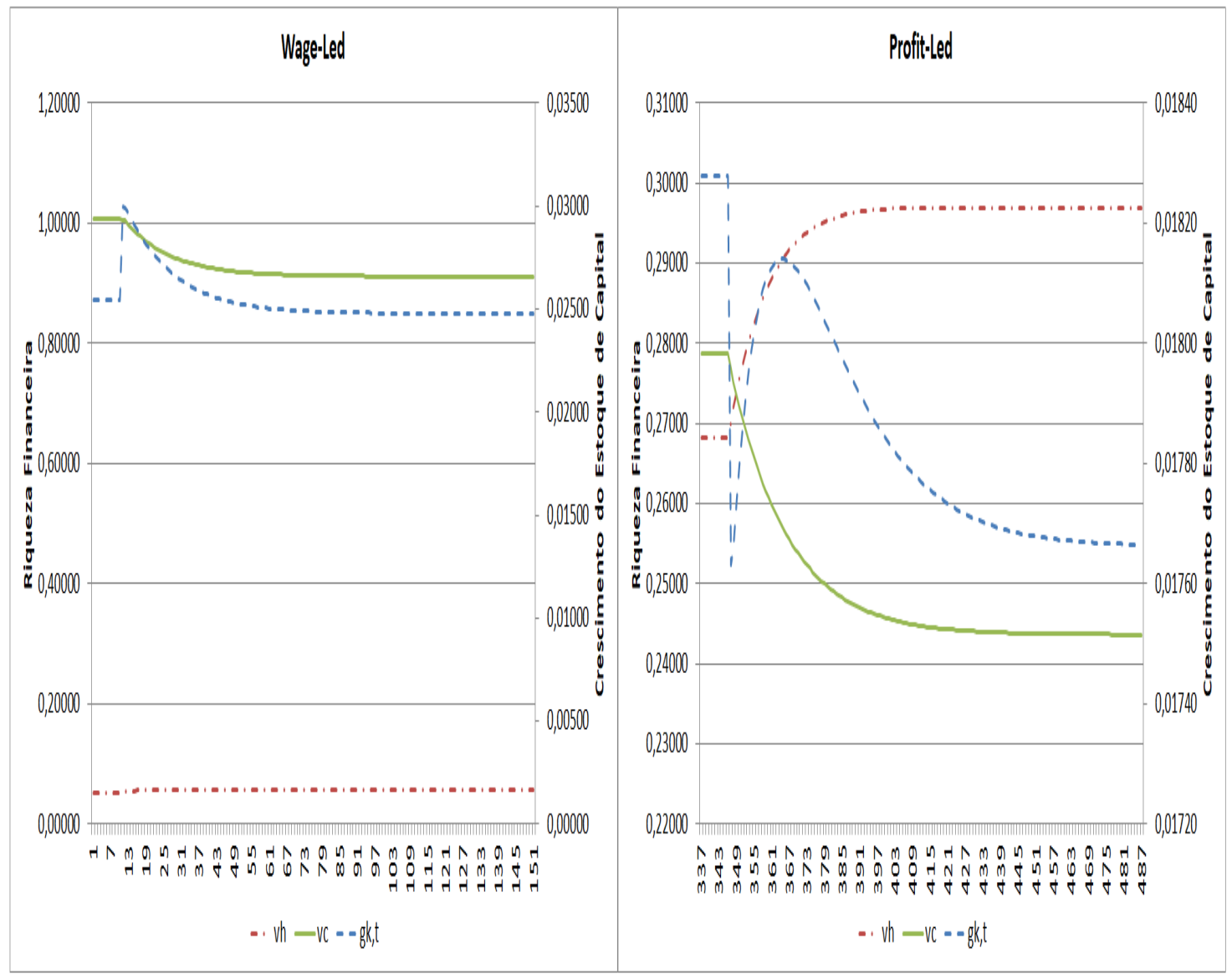

Tanto a proporção dos trabalhadores na distribuição da riqueza como na repartição líquida da renda tem uma elevação no período do choque, como as Figuras 6 e 8 mostram, devido ao aumento da renda disponível em favor dos trabalhadores. Assim, diferentemente do choque na propensão a consumir dos trabalhadores mais qualificados, os efeitos de ambas as variáveis têm correlação positiva entre si no curto e no longo prazo.

\section{Robustez}

O efeito dinâmico do aumento da participação dos salários na renda é consequência da ampliação da riqueza dos trabalhadores mais qualificados concomitante à queda, relativa ao estoque de capital, da riqueza dos capitalistas. Para tentar modificar os resultados anteriormente apresentados é preciso reduzir a importância da riqueza dos capitalistas. Apenas se a queda desta for menos relevante para a dinâmica que o aumento da riqueza dos trabalhadores, a utilização de capacidade pode aumentar do longo prazo. 
Figura 16 - Efeito do aumento de $10 \%$ na parcela de salários na renda $\left(\psi_{W}\right)$ na parcela dos trabalhadores na repartição líquida da renda $\left(\varphi_{D L}\right)$ e na taxa de lucros $(\sigma)$

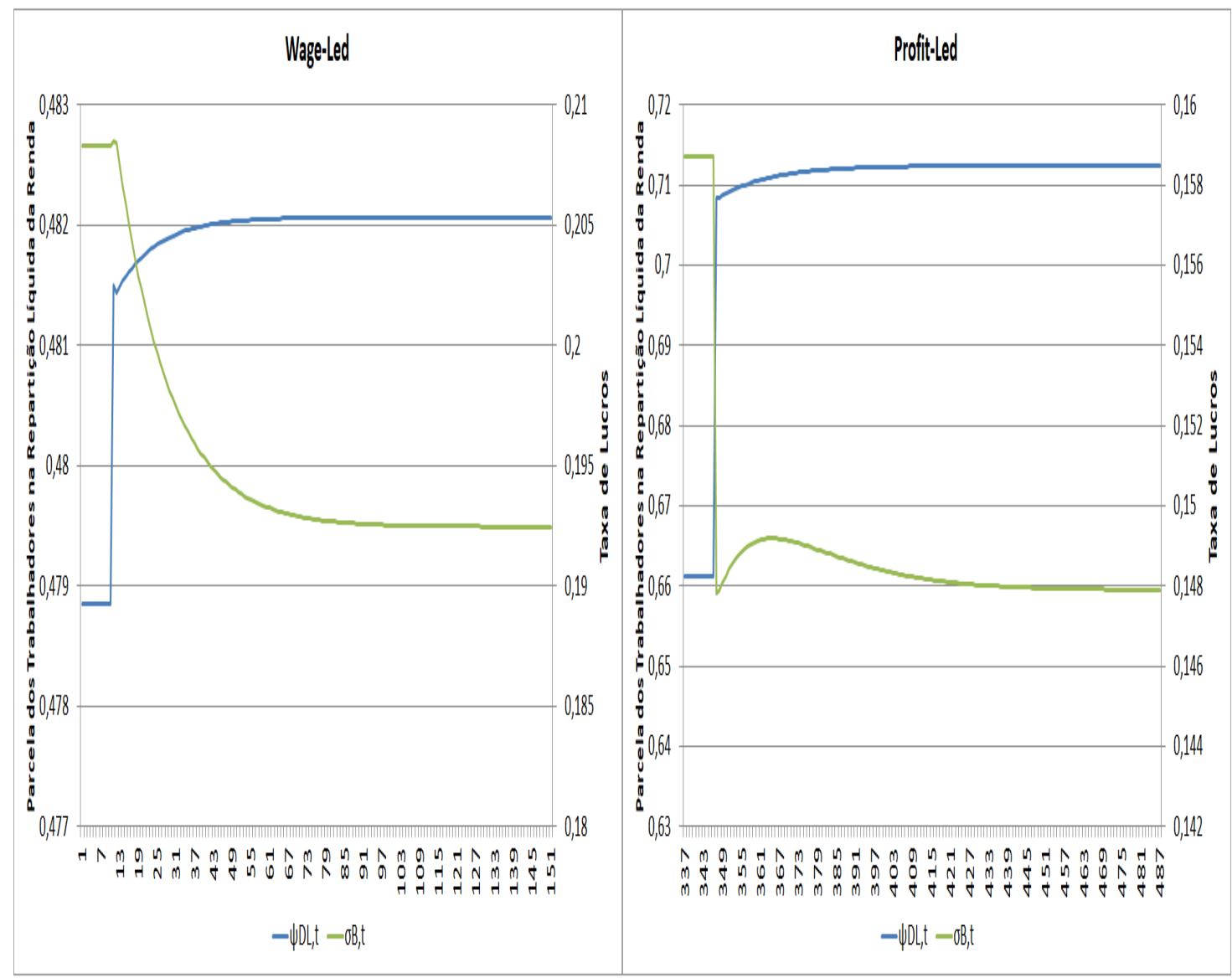

Na economia wage-led, a redução para zero dos fatores que impactam diretamente a riqueza no produto, ou seja, na propensão a consumir sobre a riqueza dos capitalistas e na alíquota de imposto sobre riqueza dos capitalistas apenas atenuam a queda na utilização de capacidade (de 1,5\% para 0,5\%). A redução destes parâmetros eleva a riqueza dos capitalistas, aumentando os títulos públicos detidos por essa classe o que intensifica os fatores indiretos: consumo e tributação sobre a renda financeira. A tentativa de reverter a queda na utilização de capacidade obriga, então, reduzir os parâmetros que afetam a renda financeira. A queda para zero da tributação sobre a renda financeira dos capitalistas não é suficiente para inverter o resultado. Contudo, ao diferenciar a propensão a consumir sobre a renda disponível em duas, uma sobre os lucros e outra sobre a renda financeira, com essa última caindo para a 0,02 (redução de 97\%), a economia passa a ser wage-led também no longo prazo. Assim, dado que as mudanças são muito drásticas é possível garantir certa robustez nesse regime de demanda.

No regime profit-led, as alterações são relativamente mais simples. Nessa economia, como a propensão a consumir dos trabalhadores mais qualificados e a alíquota sobre os salários são menores, a capacidade de acumular riqueza dessa classe é maior. Além disso, 
tal capacidade é menor para os capitalistas, uma vez que a alíquota de imposto sobre os lucros e a sensibilidade do investimento sobre os lucros são maiores. Assim, o efeito dinâmico aumenta a importância dos trabalhadores mais qualificados relativamente à dos capitalistas. É por esta razão que a queda na utilização de longo prazo após o choque na parcela de salários na renda em direção aos trabalhadores é menor nesse regime de demanda $(0,16 \%)$.

Ainda assim, reduções para zero na tributação e na propensão a consumir sobre a riqueza dos capitalistas e na tributação sobre a renda financeira dos capitalistas são insuficientes para reverter a queda na utilização de capacidade. Se propensão a consumir sobre a renda financeira dos capitalistas fosse reduzida para 0,66 (queda de 6\%), no longo prazo, a economia passaria a ter uma utilização de capacidade superior à observada antes do choque. Dessa forma, o papel da riqueza leva a um resultado contra intuitivo. Após aumentos na parcela de salários na renda, economias profit-led têm uma tendência maior a elevarem a utilização de capacidade no longo prazo do que as economias wage-led.

\subsubsection{Distribuição de Salários}

Assim como no caso do choque na parcela de salários na renda, variações na distribuições de salários também têm efeitos diferentes nos dois regimes de demanda. O aumento permanente de $10 \%$ na proporção dos salários dos trabalhadores menos qualificados no total de salários, $\psi_{L, t}$, tem um impacto positivo na utilização de curto prazo em ambos os regimes de demanda. No longo prazo, como a Figura 16 mostra, a utilização permanece superior no caso wage-led, enquanto que na economia profit-led o efeito no grau de utilização de capacidade é negativo.

A análise das fontes de demanda mostra que em ambos os regimes de demanda a fonte de demanda derivada dos salários e lucros tem um grande crescimento, puxando a utilização da economia. Além disso, como mostra a Figura 18, o efeito é consideravelmente maior no caso wage-led ( $0,24 \%$ contra $0,06 \%)$. Isso ocorre porque i) o multiplicador keynesiano é mais elevado do que no caso profit-led. ii) os estoques na economia wage-led são consideravelmente mais elevados devido à maior poupança dos capitalistas ${ }^{13}$. Ademais, no período seguinte ao choque, o crescimento dos estoques se reduz em ambos os regimes, ainda que com mais intensidade também no regime wage-led. Isto é consequência da enorme queda da riqueza dos trabalhadores mais qualificados, como mostra a Figura 19.

No regime wage-led, a demanda dos trabalhadores mais qualificados por títulos públicos se eleva no curto prazo devido ao crescimento do produto, que puxa a sua renda disponível. É por isso que a utilização ainda tem um leve aumento no período seguinte ao choque. No caso profit-led, como o crescimento do produto é mais reduzido a queda na 
Figura 17 - Efeito do aumento de $10 \%$ na distribuição de salários $\left(\psi_{L}\right)$ na utilização $\left(u^{*}\right)$ e na proporção dos trabalhadores mais qualificados na riqueza financeira total $\left(\varphi_{V}\right)$

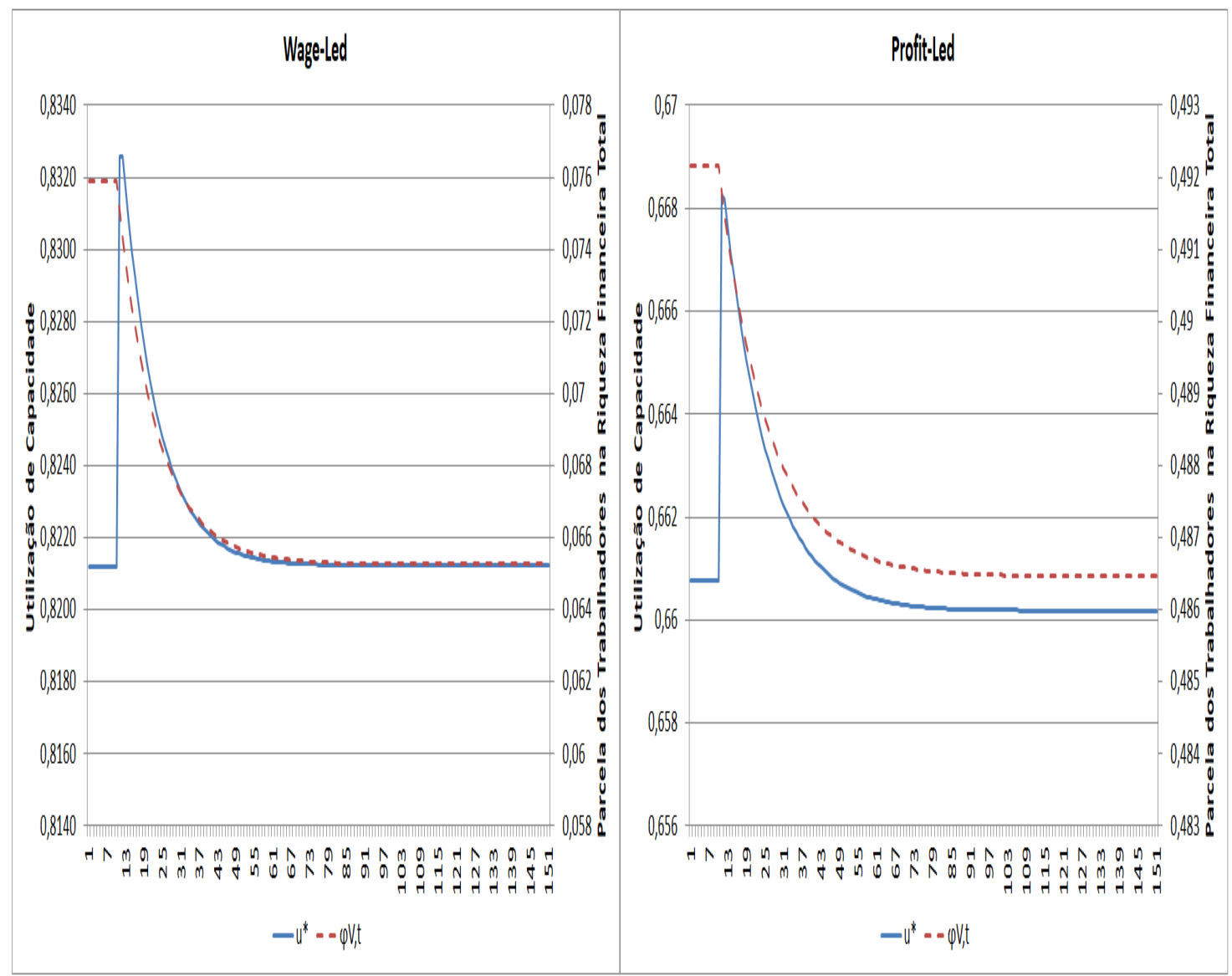

igualdade dos salários acarreta em um aumento modesto nos títulos públicos dessa classe, fazendo com que a parcela dos trabalhadores mais qualificados na renda financeira sofra um leve incremento, insuficiente para manter a utilização em um patamar superior ao dos períodos anteriores ao choque. Além disso, como durante a transição, o efeito riqueza torna-se mais crucial, os títulos públicos nas mãos dos trabalhadores mais qualificados em proporção do estoque de capital reduzem-se. No longo prazo a redução é mais intensa no caso wage-led (15\% e 1,1\%) devido a maior alíquota sobre os salários.

Em ambos os regimes de demanda, no curto prazo, o aumento da utilização leva a um aumento na demanda de títulos públicos pelos capitalistas. Durante a transição, assim como no caso dos trabalhadores, o efeito riqueza sobre os títulos públicos torna-se mais importante. Como a riqueza dos capitalistas, proporcionalmente ao estoque de capital, sofre uma queda no regime wage-led e um aumento no regime profit-led, o consumo dos capitalistas sobre a renda financeira aumenta neste último. Dessa forma, a composição dos gastos leva a uma queda maior, no longo prazo, da parcela dos trabalhadores mais qualificados na renda financeira total no caso wage-led do que no caso profit led $(1 \%$ e 0,5\%). Essa mesma questão faz com que a queda na parcela dos trabalhadores mais 
Figura 18 - Efeito do aumento de $10 \%$ na distribuição de salários $\left(\psi_{L}\right)$ nas fontes de determinação da demanda normalizadas)

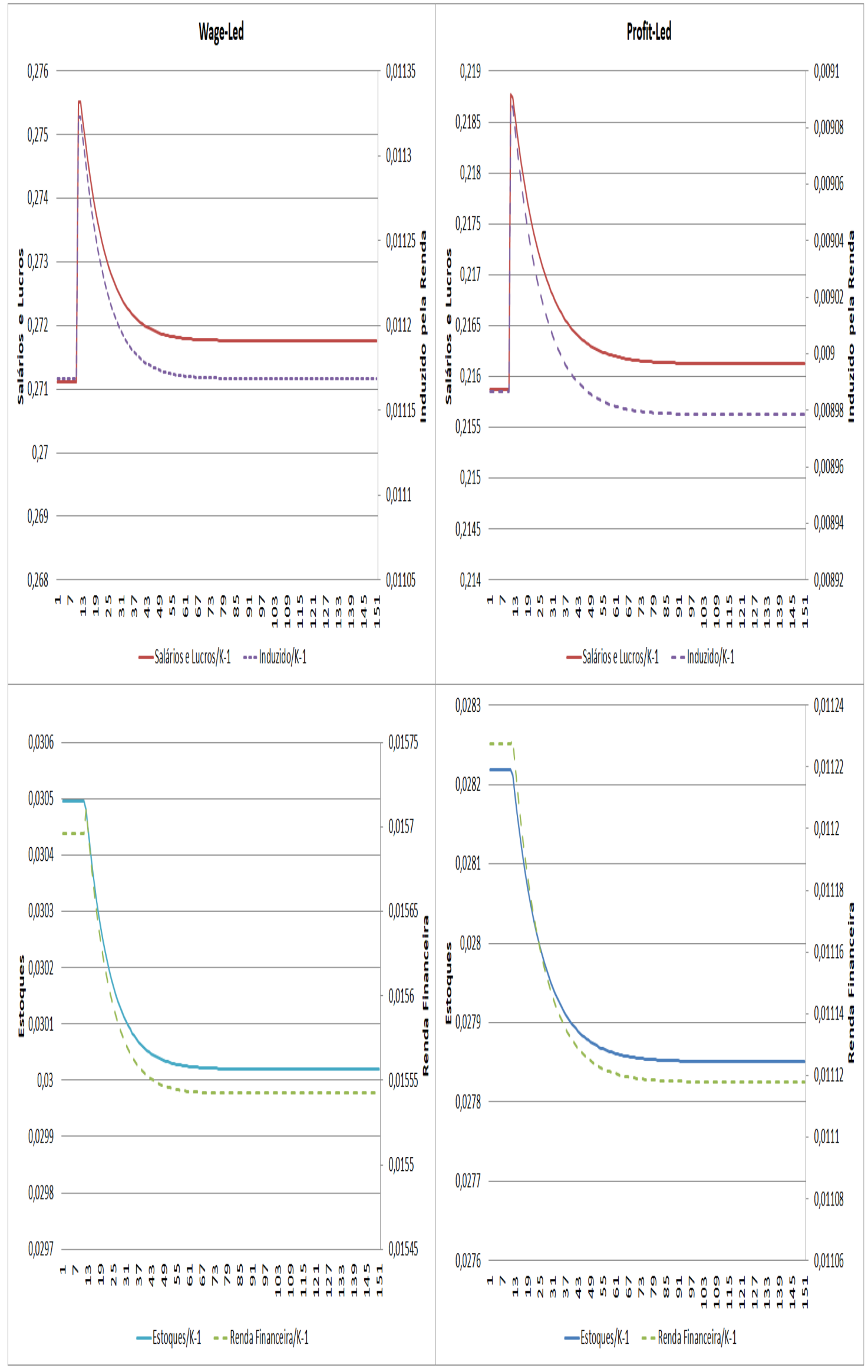


Figura 19 - Efeito do aumento de $10 \%$ na distribuição de salários $\left(\psi_{L}\right)$ na riqueza financeira dos trabalhadores normalizada $\left(v_{h}\right)$ na riqueza financeira dos capitalistas normalizada $\left(v_{c}\right)$ e no crescimento do estoque de capital $\left(g_{k}\right)$

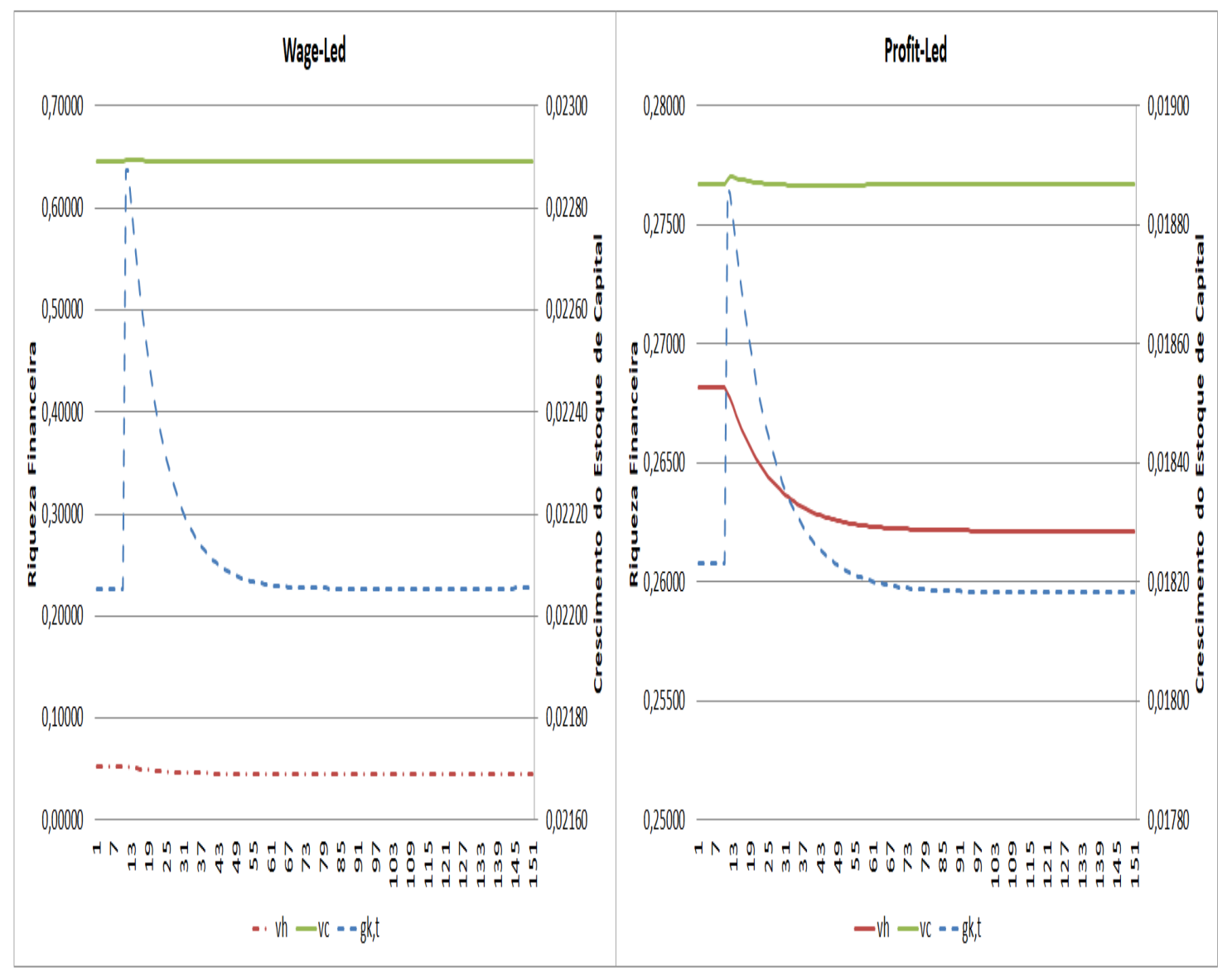

qualificados na riqueza financeira seja superior no primeiro caso do que no segundo $(1,6 \%$ e $0,7 \%)$.

Desse modo, é possível explicar a diferença no comportamento da utilização entre os regimes de demanda no longo prazo. Por um lado, ainda que os efeitos indiretos ao choque, a fonte de demanda derivada da renda financeira e a fonte de demanda derivada dos estoques tenham um efeito mais negativo no regime wage-led, o maior aumento dos efeitos diretos, isto é, a fonte de demanda dos salários e lucros, é suficientemente grande para manter a utilização levemente maior $(0,05 \%)$ do que antes do choque. Isso ocorre por causa da composição das fontes determinação do produto, pois os efeitos indiretos são respectivamente, $5 \%$ e $9 \%$, e a fonte de demanda derivada dos salários e lucros corresponde a $82 \%$ do produto. Por outro lado, no regime profit-led o fraco aumento da utilização no curto prazo é explicado justamente porque os efeitos diretos são menores. Assim, a queda dos efeitos indiretos é suficientemente grande ${ }^{14}$, acarretando em uma utilização de longo prazo menor do que nos períodos anteriores ao choque.

14 Repare que no regime wage-led o aumento do efeito direto é o dobro da queda dos efeitos indiretos. Já no regime profit-led, o primeiro é um décimo dos últimos. 
Figura 20 - Efeito do aumento de $10 \%$ na distribuição de salários $\left(\psi_{L}\right)$ na parcela dos trabalhadores na repartição líquida da renda $\left(\varphi_{D L}\right)$ e na taxa de lucros $(\sigma)$

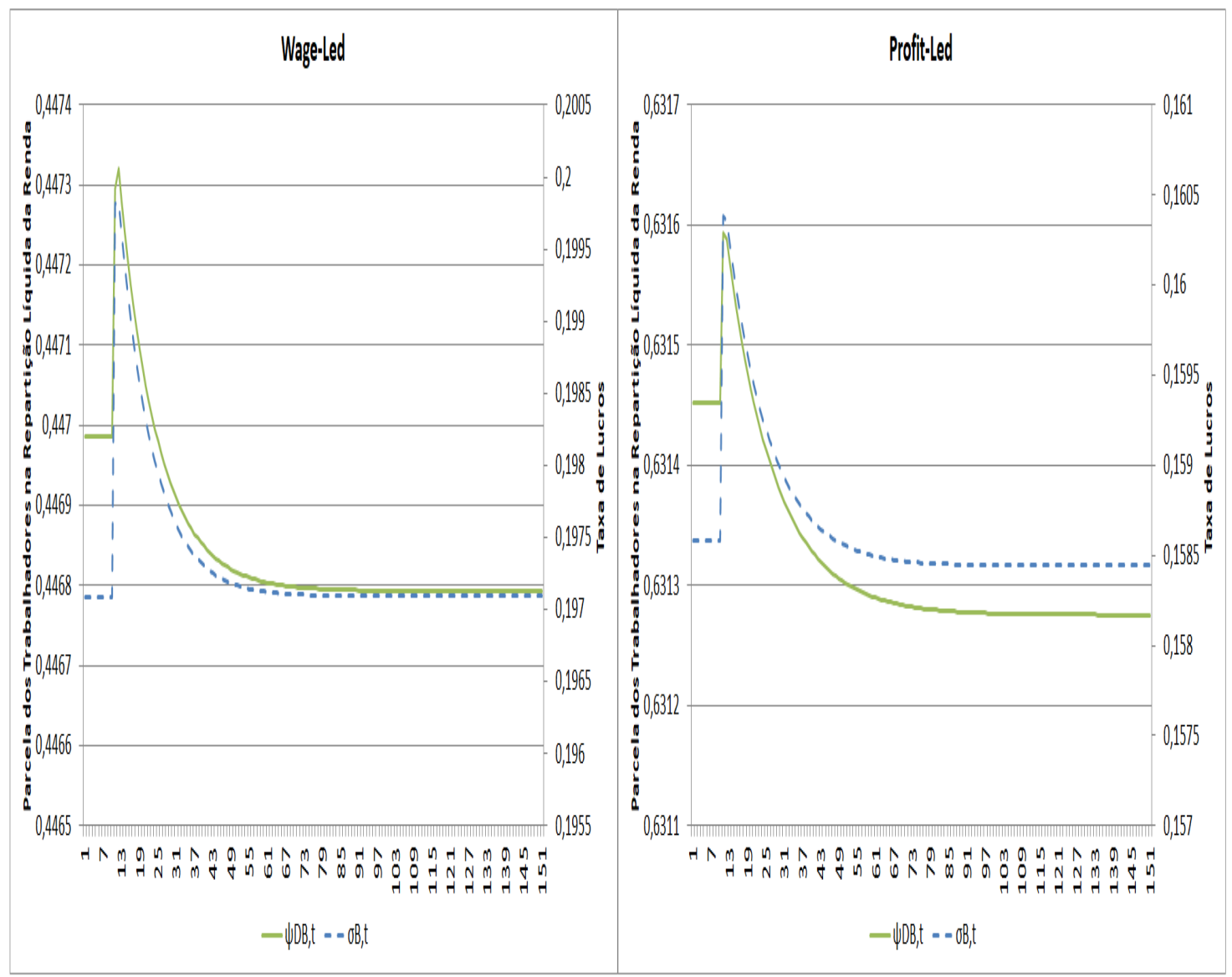

Note ainda que na economia wage-led, há uma correlação negativa nos efeitos de longo prazo na utilização e nas distribuições de riqueza e de renda. No curto prazo, a parcela dos trabalhadores na repartição líquida da renda se eleva como consequência do aumento da utilização, uma vez que a renda dos trabalhadores é mais sensível ao produto do que a renda dos capitalistas. Isso ocorre pois os salários são mais importantes para a renda dos trabalhadores do que os lucros para a renda dos capitalistas. ${ }^{15}$ Por fim, tal qual o choque na propensão a consumir sobre a riqueza dos trabalhadores mais qualificados, também há uma correlação negativa, no curto prazo, nos efeitos entre a parcela dos trabalhadores na repartição líquida de renda e na proporção da riqueza dos trabalhadores mais qualificados na riqueza financeira total. Porém, é justamente a queda da parcela dos trabalhadores mais qualificados na riqueza que faz com que, no longo prazo, a participação da renda dos trabalhadores na repartição líquida da renda caia.

\section{Robustez}

A dinâmica apresentada no aumento da igualdade na distribuição de salários é

15 Salários são 429 vezes mais relevantes do que a renda financeira dos trabalhadores, enquanto que os lucros são apenas vinte vezes maiores do que a renda financeira dos capitalistas. 
muito parecida com a observada no caso da elevação da propensão a consumir sobre a renda dos trabalhadores mais qualificados. Há um aumento do consumo dos trabalhadores (nesse caso, englobando as duas classes) reduzindo a poupança dos trabalhadores mais qualificados, mas elevando a dos capitalistas, ao aumentar a utilização.

No regime wage-led a redução da propensão a consumir sobre a renda disponível dos trabalhadores mais qualificados para 0,88 (queda de $2 \%$ ) já seria capaz de alterar a dinâmica de modo que a queda na riqueza dos trabalhadores afete significativamente a utilização, passando a reduzi-la no longo prazo. Entretanto, cabe ainda fazer outras alterações nos parâmetros para validar essa questão. Se, por exemplo, a propensão a consumir sobre a riqueza de ambas as classes fosse 0,03 (redução de 50\% para os trabalhadores mais qualificados e de $25 \%$ para os capitalistas), seria necessária que a propensão a consumir sobre a renda disponível dos trabalhadores mais qualificados caísse para 0,82 (redução de $9 \%$ ). Se a queda na propensão a consumir sobre a riqueza dos capitalistas fosse um pouco menor (redução para 0,26), não há queda na propensão a consumir sobre a renda disponível dos trabalhadores mais qualificados que faça com que uma maior igualdade salarial acarrete em um aumento de demanda.

Tal questão mostra a importância da relação entre os fluxos e os estoques da economia. Por um lado, a queda da propensão a consumir sobre a riqueza dos capitalistas eleva a utilização de capacidade, pois aumenta a poupança dos capitalistas. Isso expande a riqueza dessa classe, elevando sua detenção de títulos públicos, ampliando o consumo da renda financeira. Por outro lado, a redução da propensão a consumir sobre a renda financeira dos capitalistas também eleva a utilização, pois também aumenta a poupança dos capitalistas. Essa, ao também aumentar a riqueza, amplia o consumo sobre a riqueza dessa classe. Além disso, a redução de ambas eleva os tributos sobre riqueza e renda financeira. Dado que o governo tem propensão a consumir igual a 1, a utilização também aumenta nesse caso. Assim, supondo um limite inferior da propensão a consumir sobre a renda disponível dos trabalhadores mais qualificados igual a 0,78 (o mesmo observado na economia profit-led), se a propensão a consumir sobre a riqueza dos capitalistas for 0,26 ou menos, é possível garantir a robustez dos resultados analisados na subseção anterior.

Já no regime profit-led, a mudança do resultado para uma maior utilização de capacidade no longo prazo pode ser alcançada reduzindo a propensão a consumir sobre a riqueza dos capitalistas para 0,01 (queda de 75\%). Dessa forma, pode-se concluir que há robustez relativa nos resultados analisados na subseção anterior. No regime wage-led, uma queda pequena na propensão a consumir sobre a renda disponível dos trabalhadores mais qualificados poderia invalidar os resultados. Contudo, tal questão seria revertida com uma queda não muito grande na propensão a consumir sobre a riqueza dos capitalistas. Na economia profit-led, a mudança em um parâmetro seria suficiente para tornar os resultados menos robustos. 


\subsubsection{Política Econômica}

\subsubsection{Imposto sobre a Riqueza Financeira}

O aumento permanente de $10 \%$ na alíquota do imposto sobre a riqueza financeira, $\tau_{V}$, eleva a utilização no curto prazo, mas a reduz no longo prazo, como a Figura 21 mostra. Isso ocorre porque tal aumento eleva o gasto do governo no curto prazo, mas aumenta a tributação tanto sobre trabalhadores mais qualificados como sobre os capitalistas. Dessa forma, a capacidade das classes acumuladoras de riqueza em poupar se reduz, prejudicando o consumo derivado da renda financeira e da riqueza delas no longo prazo. O aumento da tributação é compensado pelo próprio aumento da renda das famílias, em virtude do aumento da utilização no curto prazo. É por esse motivo que a queda na utilização de capacidade é bem pequena, de 0,07\% em ambos os regimes de demanda.

Figura 21 - Efeito do aumento de $10 \%$ na taxa sobre a riqueza $\left(\tau_{V}\right)$ na utilização $\left(u^{*}\right)$ e na proporção da riqueza dos trabalhadores mais qualificados na riqueza financeira total $\left(\varphi_{V}\right)$

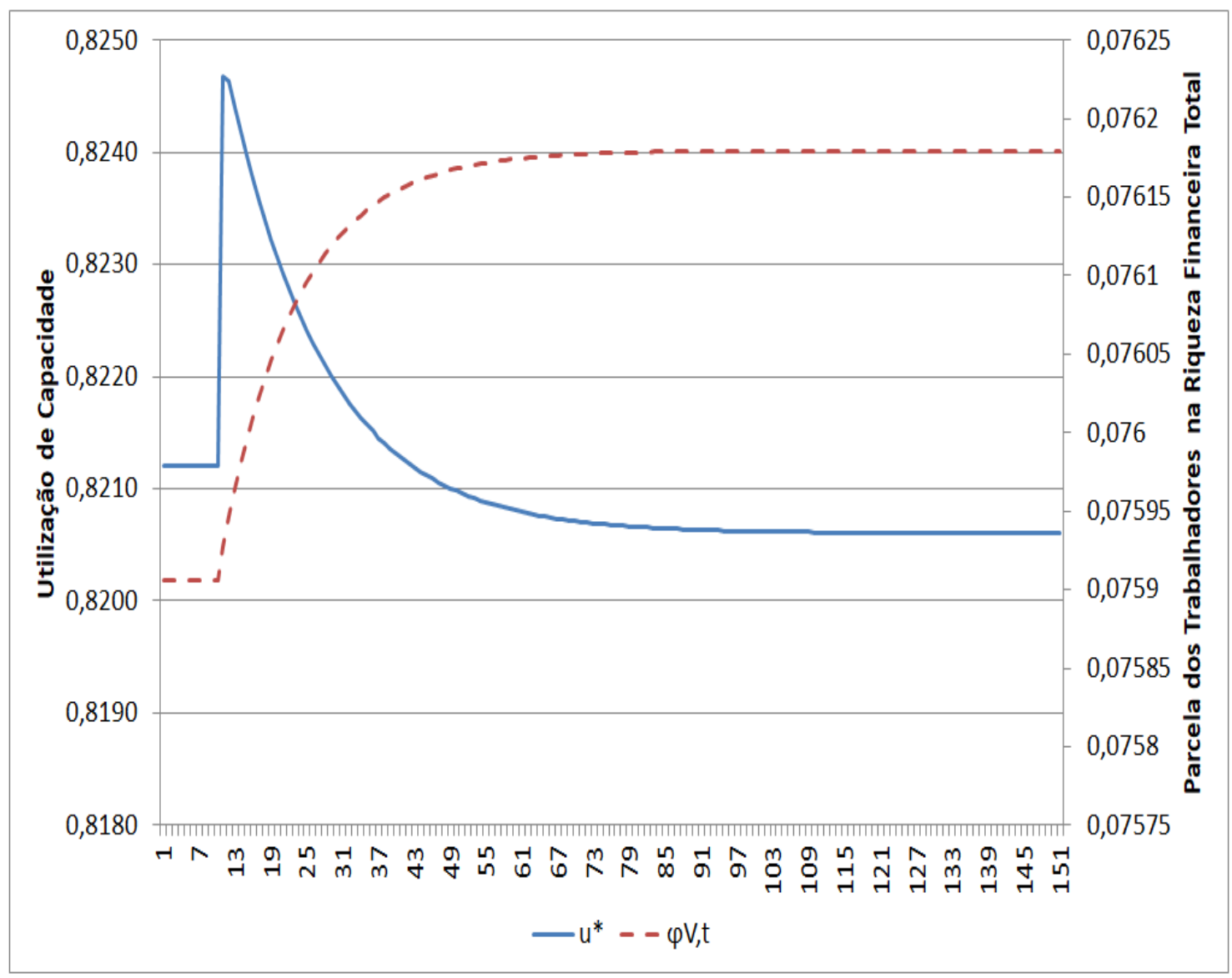

Observa-se também uma maior igualdade na distribuição de riqueza em ambos os regimes, uma vez que os capitalistas detinham inicialmente mais riqueza do que os trabalhadores mais qualificados. Assim, devido ao efeito composição, a riqueza dos primeiros cai mais do que a dos segundos. É por esta razão que no regime wage-led o aumento da 
parcela da riqueza dos trabalhadores na riqueza financeira total é mais significativo do que no regime profit-led $(0,4 \%$ contra $0,1 \%)$, ainda que tais elevações sejam pequenas.

Figura 22 - Efeito do aumento de $10 \%$ na taxa sobre a riqueza $\left(\tau_{V, t}\right)$ na parcela dos trabalhadores na repartição de renda líquida $\left(\varphi_{D L, t}\right)$ e na taxa de lucros $\left(\sigma_{t}\right)$

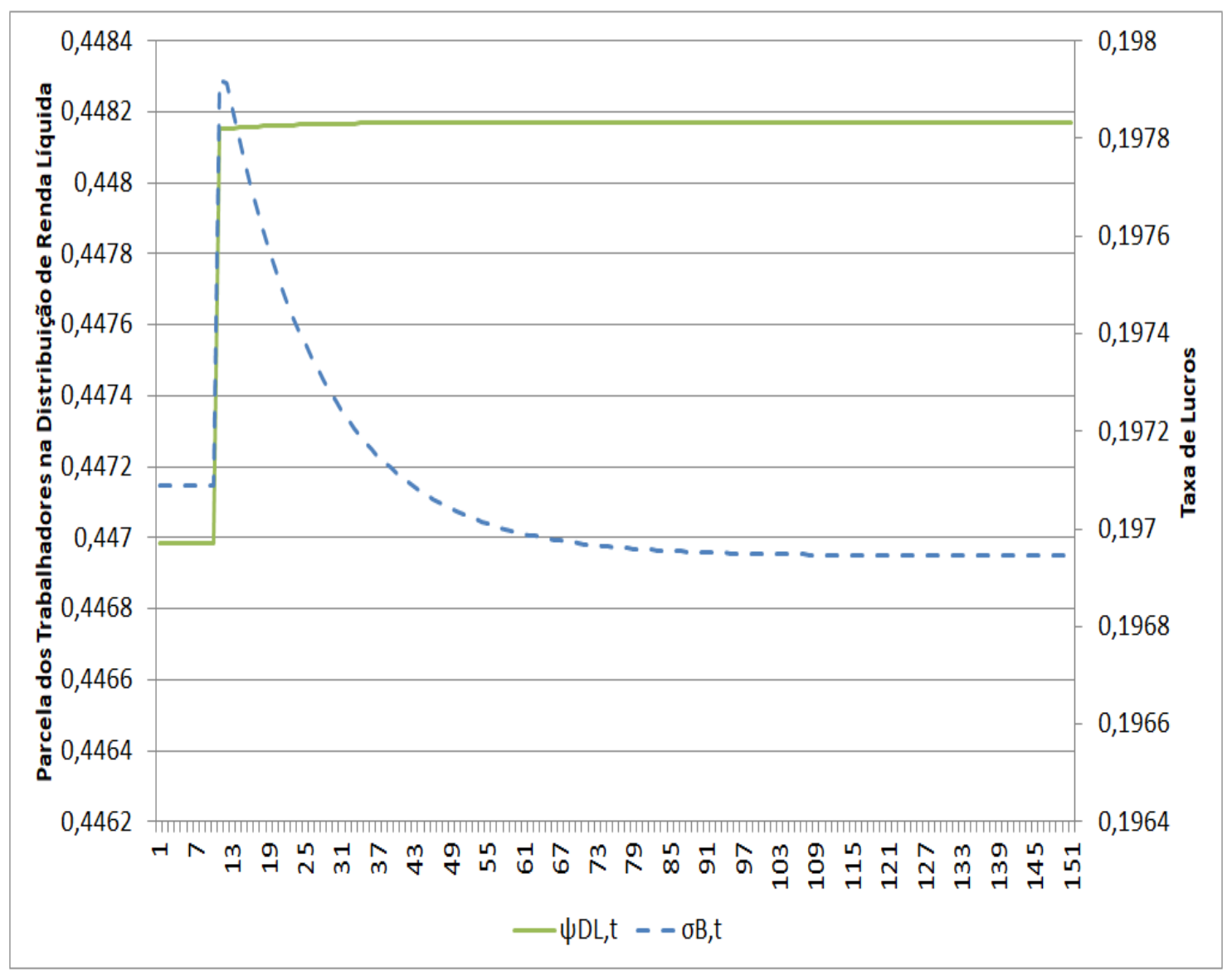

Por fim, a participação dos trabalhadores na repartição líquida de renda também varia positivamente, a despeito da queda na utilização, que onera mais os trabalhadores do que os capitalistas, como visto anteriormente. Isso ocorre porque a mudança na distribuição de riqueza em prol dos trabalhadores mais qualificados afeta também a proporção dos trabalhadores mais qualificados na distribuição de títulos públicos, e por isso, a distribuição de renda financeira também aumenta em prol dos trabalhadores.

\section{Robustez}

Quando aumenta a alíquota da tributação sobre a riqueza, a queda na utilização ocorre devido ao efeito riqueza negativo nas duas classes. Assim, há elevada robustez nos resultados, uma vez que a queda nas propensões a consumir e nos tributos apenas reforçariam a redução na riqueza, em relação ao estoque de capital, de ambas as classes, o que diminuiria ainda mais a utilização de capacidade. Cabe destacar, contudo, que se a propensão a consumir sobre a riqueza e sobre a renda financeira de ambas as classes assim 
como a tributação sobre a renda financeira fossem a zero, o choque teria efeito positivo. Isso aconteceria porque a riqueza só seria impactada pelo gasto do governo.

\subsubsection{Taxa de Juros}

Uma vez que o aumento permanente de $10 \%$ da taxa de juros eleva a renda daqueles que detêm títulos públicos, a utilização de capacidade se eleva no longo prazo em ambos os regimes de demanda. Cabe ressaltar que os gastos do governo não são impactados negativamente, pois é possível elevar o valor da dívida de modo a compensar o aumento do seu custo.

Figura 23 - Efeito do aumento de $10 \%$ na taxa de juros $(r)$ na utilização $\left(u^{*}\right)$ e na proporção dos trabalhadores mais qualificados na distribuição de riqueza financeira $\left(\varphi_{V}\right)$

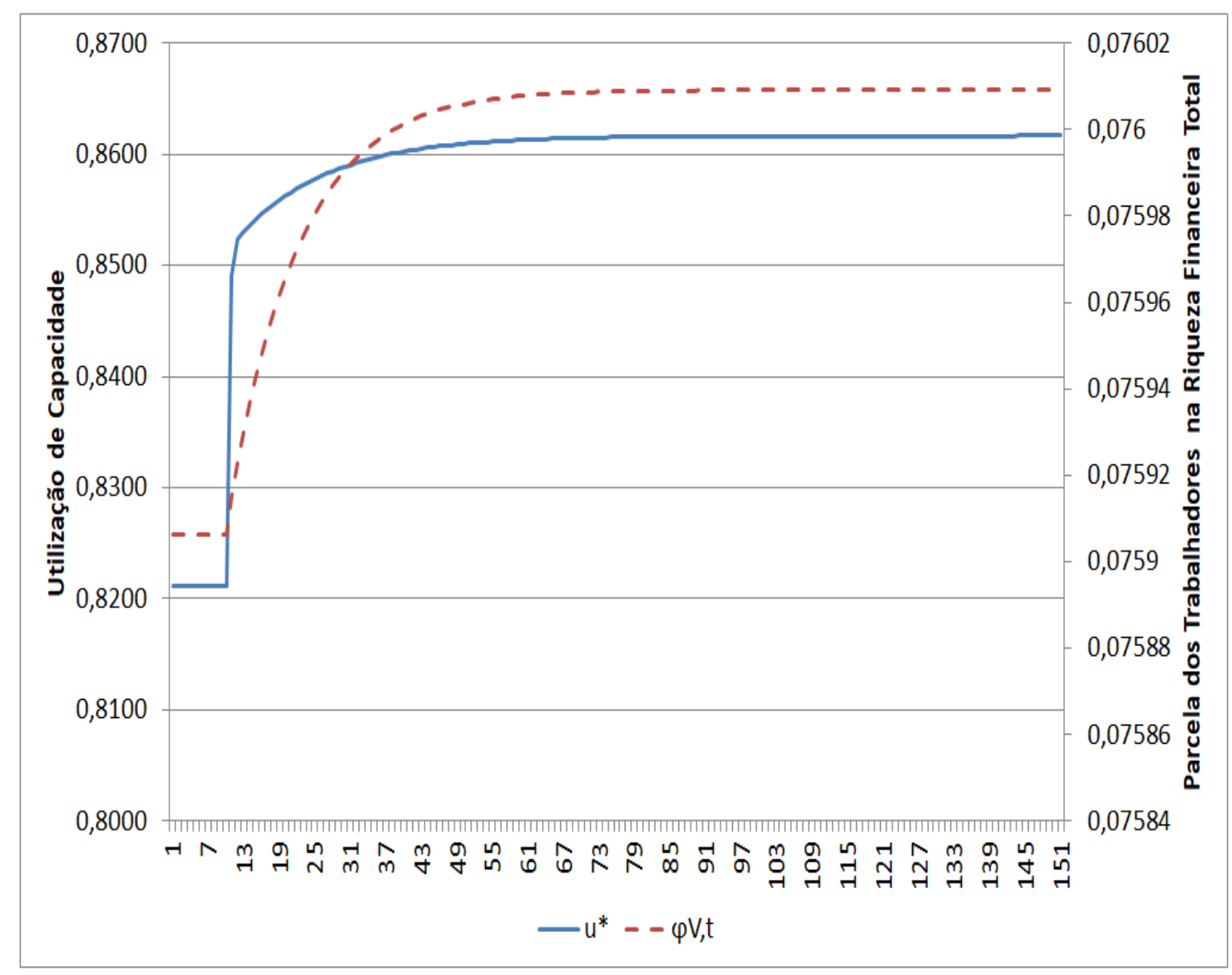

Por outro lado, o efeito na repartição líquida da renda sofre um efeito distinto a depender do regime de demanda. No caso wage-led, como os trabalhadores retêm uma parcela baixa de títulos públicos, a renda disponível desta classe é pouco afetada pela taxa de juros, enquanto que o oposto ocorre no caso profit-led. É por isso que no segundo caso, a parcela dos trabalhadores na repartição líquida da renda tem um leve aumento $(0,3 \%)$ enquanto que no primeiro ocorre uma queda $(0,4 \%)$. Destaca-se que no regime wage-led a renda dos capitalistas é ainda mais dependente dos títulos públicos do que 
a dos trabalhadores qualificados. Portanto, a elevação da proporção dos trabalhadores na repartição líquida da renda deriva-se do aumento de utilização, que impacta mais os trabalhadores do que os capitalistas, como visto anteriormente.

Figura 24 - Efeito do aumento de $10 \%$ na taxa de juros $(r)$ na parcela dos trabalhadores na repartição de renda líquida $\left(\varphi_{D L}\right)$ e na taxa de lucros $(\sigma)$

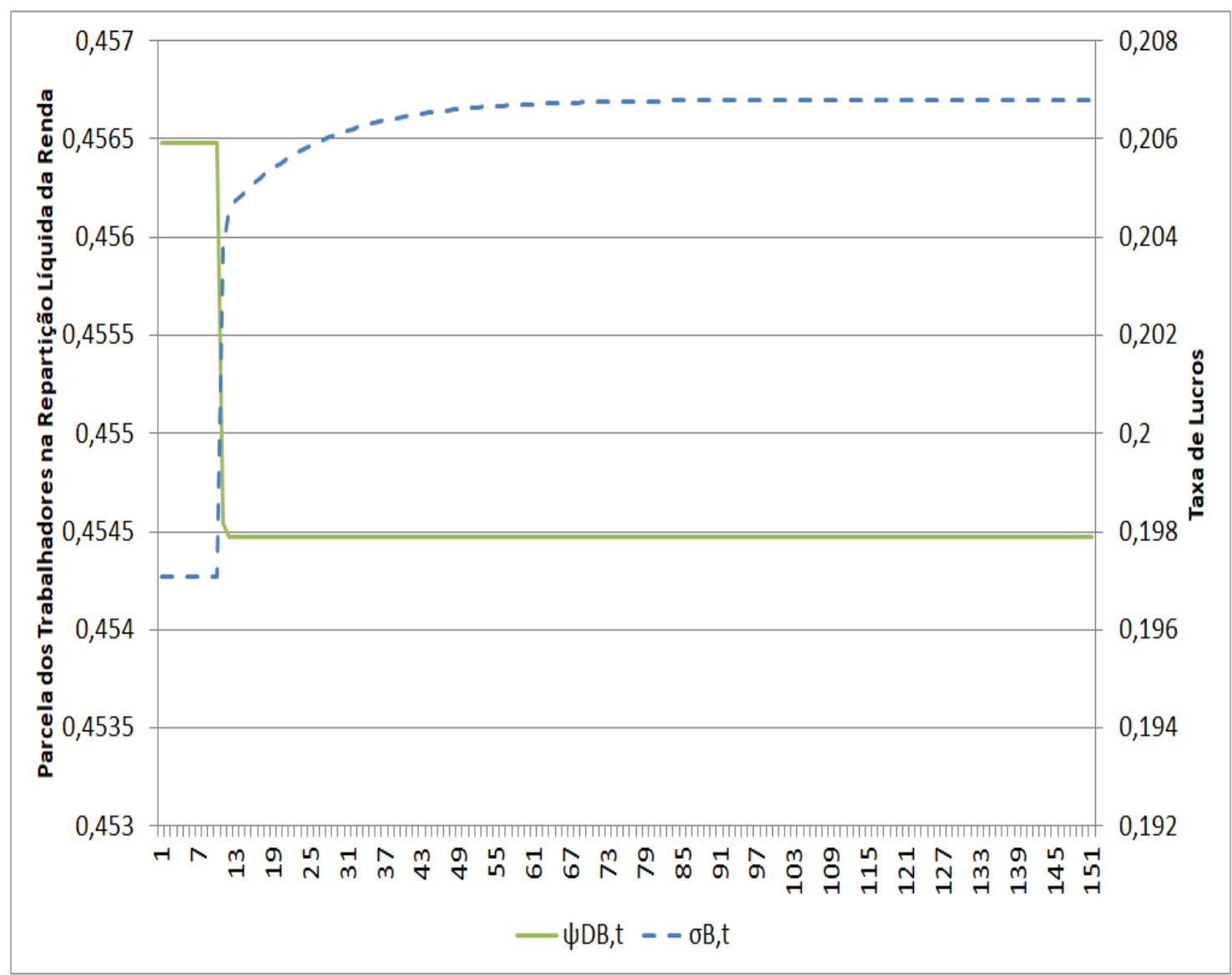

Por fim, como a Figura 23 mostra, a parcela da riqueza detida pelos trabalhadores se eleva em ambos os regimes. Isso se deve ao fato da razão renda disponível sobre riqueza dos trabalhadores ser consideravelmente maior que a dos capitalistas $(0,8$ contra 0,2$)$. Por isso, o aumento da renda disponível tem um impacto maior na acumulação de riqueza. Dessa forma, embora a parcela dos trabalhadores na repartição da renda caia no regime wage-led, o efeito composição renda-riqueza das classes é mais relevante, aumentando a igualdade de riqueza.

Conclui-se que neste choque há correlação positiva entre os efeitos na parcela dos trabalhadores na distribuição de riqueza e na utilização de capacidade. Ademais, no regime profit-led a correlação positiva dos efeitos ainda inclui a parcela dos trabalhadores na repartição líquida da renda.

\section{Robustez}


Uma vez que o aumento da taxa de juros é só injeção de demanda, nenhuma variação nos parâmetros é capaz de alterar o resultado na utilização de capacidade de longo prazo. Contudo, em ambos os regimes, ao supor que a relação entre as propensões a consumir sobre a riqueza das classes, $\frac{\theta_{h}}{\theta_{c}}$, é inferior a 1,5, o efeito da queda da participação dos trabalhadores na renda torna-se mais relevante do que a composição renda-riqueza. Assim, os trabalhadores passam a deter uma parcela menor da riqueza.

\subsubsection{Superavit Primário}

A queda permanente de $10 \%$ da meta de superavit primário, ao aumentar os gastos do governo, expande a demanda, elevando a utilização de capacidade. Ao aumentar a renda das famílias, a capacidade de poupança delas é ampliada fazendo com que o produto tenha um efeito contínuo sobre a demanda, ao elevar a riqueza financeira das famílias. Uma vez que a renda dos trabalhadores mais qualificados é mais suscetível a elevações da utilização, a parcela dos trabalhadores na riqueza e na repartição da renda também se eleva.

Figura 25 - Efeito da queda de $10 \%$ no superavit primário $(\omega)$ na utilização $\left(u^{*}\right)$ e na proporção da riqueza dos trabalhadores mais qualificados na distribuição de riqueza financeira $\left(\varphi_{V}\right)$

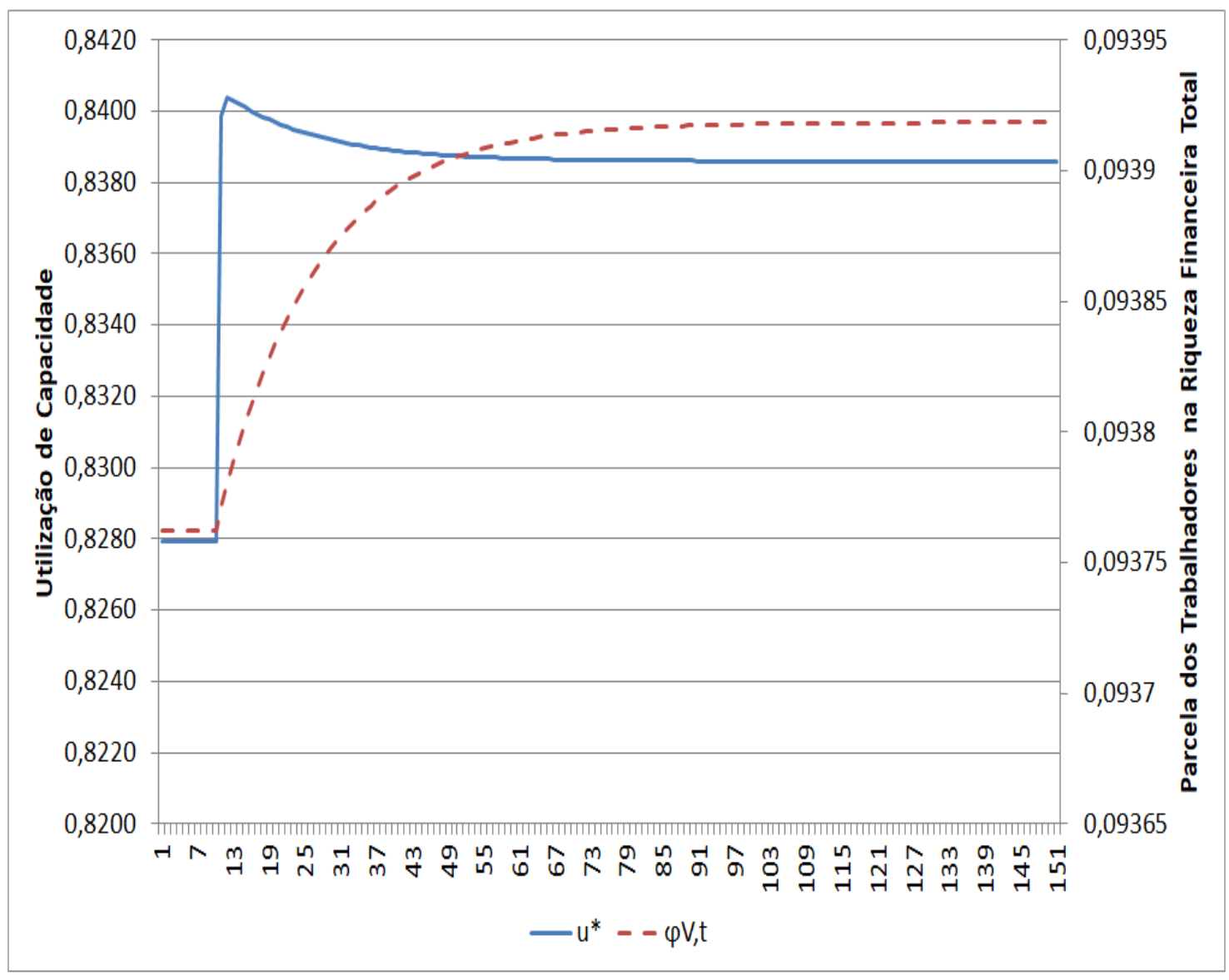

Dessa forma, esse é o único choque que há correlação positiva nos efeitos nas três variáveis: utilização de capacidade, parcela dos trabalhadores na repartição da renda e 
parcela da riqueza dos trabalhadores mais qualificados na riqueza financeira total. Além disso, a cadeia de causalidade é da primeira para a segunda. E a segunda para a terceira possuem um mecanismo de retroalimentação. Inicialmente, o aumento na parcela dos trabalhadores na repartição da renda gera uma elevação da igualdade de riqueza. Esta, ao redistribuir a renda financeira traz uma nova rodada de aumento da proporção dos trabalhadores na repartição da renda e daí em diante. Cabe ressaltar, contudo, que a despeito da utilização ter um aumento considerável (aproximadamente 1,4\% em ambos os regimes), as variáveis de distribuição tem um impacto mais discreto ( $0,3 \%$ na proporção da riqueza dos trabalhadores mais qualificados na riqueza financeira total e $0,01 \%$ na parcela dos trabalhadores na repartição líquida da renda).

Figura 26 - Efeito da queda de $10 \%$ no superavit primário $(\omega)$ na parcela dos trabalhadores na repartição de renda líquida $\left(\varphi_{D L}\right)$ e na taxa de lucros $(\sigma)$

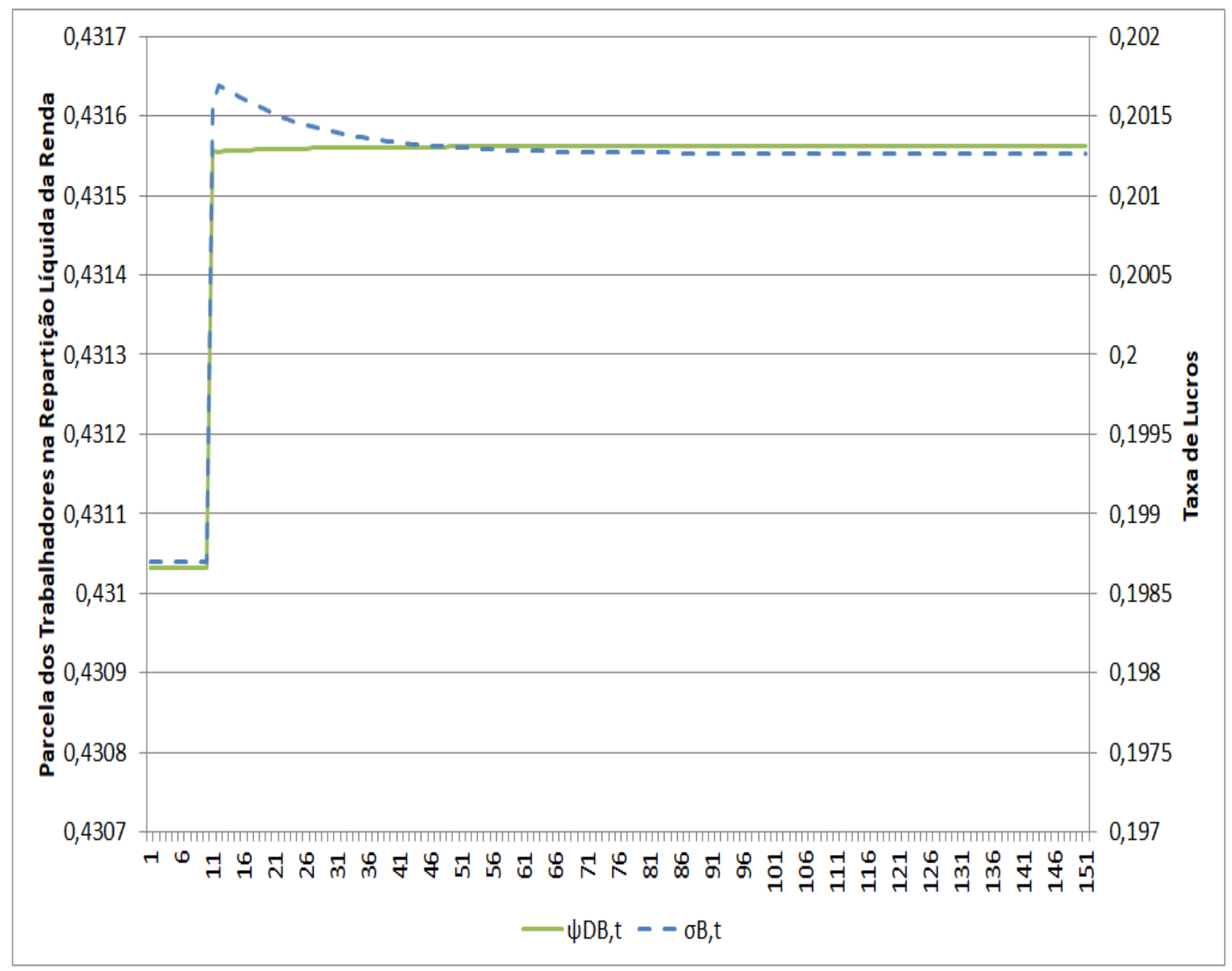

\section{Robustez dos Resultados}

Assim como no choque positivo na taxa de juros, a redução no superávit primário apenas tem efeito positivo na demanda, sem prejudicar a riqueza de nenhuma classe. Além disso, não é nenhuma mudança possível nos parâmetros que possa modificar os efeitos de longo prazo das variáveis distributivas. 


\subsection{Discussão}

Em todos os choques apresentados, os efeitos de longo prazo ou alteraram os resultados de curto prazo ou trouxeram uma nova composição para os mesmos, em alguns acentuando e em outros atenuando. Em uma economia cada vez mais financeirizada, é importante entender a influência da acumulação da riqueza financeira sobre as demais variáveis econômicas, pois esta, diferentemente do que acontece em Pasinetti (1962), não altera a composição do estoque de capital entre trabalhadores e capitalistas.

Como visto no experimento que elevou a parcela de salário na distribuição funcional da renda, ainda que uma economia seja wage-led no curto prazo, o efeito riqueza da classe que mais poupa é tão significativo que a utilização de capacidade se reduz no longo prazo, a despeito do aumento inicial. Ademais, ainda que pelos parâmetros utilizados a economia profit-led de curto prazo também o seja no longo prazo, tal regime de demanda precisa de parâmetros mais plausíveis, comparados à economia wage-led de curto prazo, para ser wage-led no longo prazo. O aumento das propensões a consumir sobre a renda disponível e sobre a riqueza leva a uma queda na utilização, a despeito do modelo ser liderado pela demanda.

Se os parâmetros que determinam a renda disponível e o comportamento dos trabalhadores mais qualificados resultarem em uma pequena poupança, uma maior igualdade salarial eleva a utilização e, assim, a queda da renda e riqueza desses trabalhadores em proporção do estoque de capital não necessariamente leva a uma menor utilização de capacidade. Tal resultado indica que os efeitos diretos no consumo a partir dos salários e lucros, como visto nos modelos da literatura Kaleckiana no Capítulo 1, devem ser somados aos efeitos indiretos sobre a riqueza e renda financeira. Ainda que o efeito riqueza seja relevante na maioria dos casos, ele não é suficiente para entendermos a dinâmica de longo prazo.

Para melhor sintetizar os resultados apresentados, a Tabela 6 indica os efeitos do choque na utilização de capacidade, na parcela dos trabalhadores na repartição da renda líquida e na proporção da riqueza dos trabalhadores mais qualificados na riqueza financeira total. Para melhor entender a intensidade, o número de sinais representa o quão significativo foi o choque ${ }^{16}$.

Uma queda de $20 \%$ no superavit primário e uma elevação de $10 \%$ na taxa de juros acarretam em uma substancial elevação da utilização (7,8\% no regime wage-led e 5,5\% quando é profit-led), mas o impacto é muito reduzido na proporção dos trabalhadores mais qualificados na distribuição de riqueza financeira (menos de $1 \%$ em ambos os regimes) e na

16 Se há apenas um sinal, o efeito é pequeno, na segunda casa decimal ou menor. Com dois sinais, o impacto é menor que 1\%, mas maior que duas casas decimais. Os três sinais representam variações entre $1 \%$ e $10 \%$. Por fim, os quatro sinais mostram efeitos superiores a $10 \%$. Cabe destacar que os aumentos nas propensão a consumir sobre a renda disponível foram metade dos demais, apenas $5 \%$. 
Tabela 5 - Efeito de choques das varáveis exógenas na utilização, u*, na proporção da riqueza dos trabalhadores mais qualificados na riqueza financeira total, $\varphi_{V, t}$ e na proporção dos trabalhadores na repartição líquida da renda, $\psi_{D L, t}$

\begin{tabular}{|l|l|l|l|l|l|l|}
\hline & \multicolumn{2}{|l|}{ Wage-Led } & \multicolumn{3}{|c|}{ Profit-Led } \\
\hline & $u^{*}$ & $\varphi_{V, t}$ & $\psi_{D L, t}$ & $u^{*}$ & $\varphi_{V, t}$ & $\psi_{D L, t}$ \\
$\omega_{t}$ & +++ & ++ & ++ & +++ & ++ & + \\
$\tau_{V, t}$ & - & ++ & ++ & - & ++ & + \\
$\beta_{h, t}$ & -- & --- & -- & -- & --- & -- \\
$\beta_{c, t}$ & --- & ++++ & ++ & --- & +++ & ++ \\
$\theta_{h, t}$ & - & -- & - & - & --- & - \\
$\theta_{c, t}$ & -- & +++ & ++ & -- & +++ & ++ \\
$r_{t}$ & +++ & ++ & -- & +++ & ++ & ++ \\
$\psi_{W, t}$ & --- & ++++ & ++++ & - & ++++ & +++ \\
$\psi_{L, t}$ & + & ---- & - & + & -- & - \\
\hline
\end{tabular}

parcela dos trabalhadores na repartição da renda (próximo a zero em ambos os regimes, sendo que negativo no caso wage-led). Mantendo as alterações anteriores, se o governo deixasse de taxar a riqueza dos trabalhadores mais qualificados, a proporção da riqueza dos trabalhadores mais qualificados na riqueza financeira total aumentaria em ambos os regimes aproximadamente $2 \%$, enquanto que o efeito na parcela dos trabalhadores na repartição da renda seria quase nulo.

Por enquanto todas as mudanças podem ser consideradas de baixa dificuldade política, pois não reduzem a renda ou riqueza de nenhuma classe, ainda que modifiquem as parcelas de tais variáveis entre as classes. Cabe ressaltar que a parcela da riqueza financeira pertencente aos trabalhadores mais qualificados, no caso wage-led, é de 7,6\% e o aumento dado pelas políticas apresentadas anteriormente leva tal variável para pouco menos que 7,8\%. O governo poderia fazer uma reforma tributária e reduzir o imposto sobre os salários em $20 \%$ e elevar a tributação dos lucros em $10 \%{ }^{17}$. Como a riqueza dos capitalistas tem uma importância maior no longo prazo, a utilização deixa de subir como antes e passa a ter uma elevação de 7,4\% no regime wage-led e 4,4\% no profit-led. Além disso, a proporção dos trabalhadores mais qualficados na distribuição de riqueza passa a ter uma elevação bem mais considerável, ao redor de $9 \%$ em ambos os regimes, enquanto que a parcela dos trabalhadores na repartição líquida da renda aumenta aproximadamente $5 \%$.

A riqueza no regime wage-led continuaria muito concentrada na mão dos capitalistas, e mesmo no caso profit-led, se pensarmos que os capitalistas podem ser o $1 \%$ mais rico da população, eles ainda deteriam $30 \%$ da renda líquida e $47 \%$ da riqueza financeira. Dessa forma, é interessante pensar em outras medidas para tentar alterar a distribuição

$\overline{17}$ Essas alterações não foram analisadas anteriormente, mas a dinâmica delas é esperada, dada a redução/aumento na riqueza destas classes 
de riqueza mais significativamente. Uma elevação de 10\% da parcela dos salários na renda, por meio de uma redução na concentração do mercado ou de maior poder aos sindicatos, poderia trazer esse efeito. Isso traria uma queda no aumento da utilização para $6 \%$ e 4,3\% respectivamente nos regimes wage-led e profit-led. A proporção dos trabalhadores na riqueza financeira total aumentaria $32 \%$ no regime wage-led, alcançando 10\%, enquanto que a elevação no caso profit-led seria de $20 \%$, fazendo com que a riqueza na mão dos trabalhadores se aproximasse de $60 \%$ do total. Já a parcela dos trabalhadores na repartição líquida da renda aumentaria $14 \%$ em ambos os regimes.

Ainda assim, no regime wage-led, os capitalistas continuariam a deter altas parcelas da renda e riqueza. Os capitalistas ainda deteriam $90 \%$ de toda a riqueza financeira e mais de $48 \%$ da repartição líquida da renda. Seria, portanto, necessária uma medida muito mais radical. O governo poderia então tomar $0,01 \%$ da propriedade da riqueza financeira dos capitalistas e transferir para os trabalhadores mais qualificados em todo período. Assim, a utilização se elevaria ainda menos (3,9\% no regime wage-led). Contudo, o aumento da proporção dos trabalhadores na riqueza financeira total seria significativo, alcançando $170 \%$ e a parcela dos trabalhadores na repartição líquida da renda aumentaria 17\%. Para melhor sintetizar os efeitos, a Tabela 7 mostra os resultados a cada rodada de política do Estado.

Tabela 6 - Efeito de políticas Estatais na utilização, $u^{*}$, na proporção da riqueza dos trabalhadores mais qualificados na riqueza financeira total, $\varphi_{V, t}$ e na parcela dos trabalhadores na repartição líquida da renda, $\psi_{L D, t}$

\begin{tabular}{|c|c|c|c|c|c|c|c|c|c|c|c|c|}
\hline & \multicolumn{6}{|c|}{ Wage-Led } & \multicolumn{6}{|c|}{ Profit-Led } \\
\hline & \multicolumn{2}{|l|}{$\mathrm{u}^{*}$} & \multicolumn{2}{|c|}{$\varphi_{V, t}$} & \multicolumn{2}{|c|}{$\psi_{B D, t} / \psi_{L D, t}$} & \multicolumn{2}{|l|}{$\mathrm{u}^{*}$} & \multicolumn{2}{|c|}{$\varphi_{V, t}$} & \multicolumn{2}{|c|}{$\psi_{B D, t} / \psi_{L D, t}$} \\
\hline & Elevação (\%) & Valor & Elevação (\%) & Valor & Elevação (\%) & Valor & Elevação (\%) & Valor & Elevação (\%) & Valor & Elevação (\%) & Valor \\
\hline $\mathrm{x}$ Rodada 1 & 7,8 & 0,885 & 1 & 0,076 & $-0,2$ & 0,45 & 5,5 & 0,696 & 0,6 & 0,49 & 0,01 & 0,5 \\
\hline Rodada 2 & 7,8 & 0,885 & 2 & 0,077 & $-0,2$ & 0,45 & 5,5 & 0,697 & 2 & 0,5 & 0,1 & 0,5 \\
\hline Rodada 3 & 7,4 & 0,881 & 10 & 0,084 & 4,4 & 0,47 & 4,4 & 0,689 & 8,8 & 0,53 & 5,2 & 0,7 \\
\hline Rodada 4 & 4,6 & 0,87 & 32 & 0,1 & 15,6 & 0,51 & 4,3 & 0,689 & 21 & 06 & 12,8 & 0,75 \\
\hline Rodada 5 & 3,9 & 0,852 & 168 & 0,2 & 17,1 & 0,52 & 3,1 & 0,681 & 33 & 0,65 & 13,4 & 0,75 \\
\hline
\end{tabular}

Assim, é possível concluir que uma distribuição de riqueza mais igualitária está associada a uma queda na utilização de capacidade (na maioria dos casos) uma vez que a dinâmica da riqueza dos capitalistas é mais forte que a dos trabalhadores mais qualificados, pois estes poupam uma parcela consideravelmente maior da sua renda. Cabe destacar, entretanto, que essa relação é apenas uma correlação e não uma causalidade, uma vez que é possível uma combinação de choques que alterem na mesma direção ambas as variáveis, utilizando o superávit primário e a taxa de juros para compensar a queda na utilização. Além disso, mudanças significativas na proporção dos trabalhadores mais qualificados na distribuição de riqueza financeira e na parcela dos trabalhadores na retenção líquida da renda são muito difíceis. Políticas tributárias têm efeito pouco relevantes em ambas as variáveis. Para as aumentá-las é preciso tomar medidas com maiores dificuldades políticas. A proporção da riqueza financeira nas mãos dos trabalhadores mais qualificados só sofre alteração relevante se há uma apropriação da riqueza dos mais ri- 
cos, repassando aos trabalhadores. Já a parcela dos trabalhadores na repartição líquida da renda só tem alguma elevação após mudanças na distribuição funcional em prol dos salários. Ademais, os parâmetros comportamentais, propensões a consumir sobre a renda disponível e riqueza tem efeitos significativos, acarretando em uma diferença grande nas variáveis distributivas. 



\section{Conclusão}

Esta pesquisa inspira-se nos trabalhos empíricos de Piketty (2014) e Garbinti, Goupille-Lebret e Piketty (2017), que evidenciam que a parcela que os mais ricos detinham sobre a riqueza total aumentou desde o início dos anos 80, contribuindo para uma maior concentração de renda na mão do percentil mais rico da população. Como Piketty e Zucman (2015) destacam, a própria riqueza financeira se tornou extremamente relevante para explicar esse processo.

Esta dissertação partiu da literatura Kaleckiana e de suas extensões para analisar as relações entre o grau de capacidade das firmas, a proporção dos trabalhadores na riqueza financeira e a parcela dos trabalhadores na repartição líquida da renda. No que tange à literatura pós-Keynesiana que tratou da distribuição de riqueza, o trabalho dialoga diretamente com a literatura de Kaldor (1955) e Pasinetti (1962).

O primeiro capítulo revisou o arcabouço teórico Kaleckiano, enfatizando como a distribuição funcional da renda afeta a utilização de capacidade, isto é, qual o efeito de um aumento na parcela de salários na renda sobre a demanda agregada e sobre a taxa de lucros. Ademais, este capítulo buscou exibir como o a riqueza e a sua distribuição podem impactar as variáveis econômicas, apresentando o Teorema de Pasinetti (1962) e suas ramificações, assim como modelos Kaleckianos que transformam a distribuição de riqueza entre as classes em variável endógena e central.

O segundo capítulo desenvolveu o modelo teórico que trata da relação dinâmica entre a rendas das classes, a acumulação de riqueza financeira e o consumo, além da inclusão do governo e de firmas.

O modelo teórico foi desenvolvido a partir de uma economia com três classes, duas de trabalhadores e uma de capitalistas. Os trabalhadores menos qualificados recebem apenas salários, que são inteiramente consumidos, enquanto os trabalhadores mais qualificados receberem salários mais elevados e acumulam parte de sua renda em moeda e títulos públicos. Estes títulos geram pagamentos de juros, que transformam-se em uma renda financeira dos trabalhadores mais qualificados.

Já os capitalistas, ao atuarem como firmas, investem e recebem os lucros. Por pouparem parte da renda, também auferem renda financeira. Tanto os trabalhadores qualificados quanto os capitalistas têm propensão a consumir positiva sobre a sua renda disponível e sobre a riqueza. O governo tributa salários, lucros, renda financeira e riqueza, e utiliza esta tributação como forma de financiar os seus gastos.

Assim, a riqueza pode afetar a demanda agregada por quatro canais: i) pelo con- 
sumo direto sobre a riqueza; ii) pela tributação sobre a riqueza, que eleva o gasto do governo; iii) pelo consumo sobre a renda disponível, pois a riqueza impacta diretamente a renda financeira; iv) pela tributação sobre a renda financeira, que aumenta o gasto do governo. São esses quatro canais que determinam os diferentes efeitos de longo prazo de mudanças nos parâmetros sobre a utilização de capacidade, sobre a distribuição de riqueza e sobre a repartição líquida da renda.

Na solução de curto prazo, os resultados são similares aos encontrados nos modelos Kaleckianos tradicionais, isto é, ocorre o paradoxo da poupança e a ambiguidade do aumento da parcela dos salários na renda e no grau de utilização de capacidade.

Cabe destacar que a ambiguidade da distribuição funcional da renda segue não apenas aquela que foi explorada em Amadeo (1987), dada a inclusão de propensão a poupar positiva dos trabalhadores mais qualificados, como também a inclusão do governo. Ademais, observou-se que uma maior igualdade na distribuição de salários eleva a demanda agregada, pois os trabalhadores menos qualificados têm propensão a consumir sobre a renda disponível superior à dos trabalhadores mais qualificados. Por fim, aumentos da parcela da riqueza dos trabalhadores na riqueza financeira total elevam a utilização de capacidade no curto prazo, pois esta classe tem propensão a consumir sobre a riqueza mais elevada que a dos capitalistas.

No terceiro capítulo, investigou-se como mudanças nas variáveis comportamentais, de distribuição e de política econômica são capazes de alterar a dinâmica dos estoques, e por isso, modificar a utilização de capacidade, a distribuição de riqueza e a repartição líquida da renda.

No equilíbrio de longo prazo, contudo, os resultados alcançados foram divergentes dos modelos Kaleckianos tradicionais. O aumento da propensão a consumir sobre a renda disponível e sobre a riqueza de ambas as classes reduzem a utilização de capacidade no longo prazo, invalidando o paradoxo da poupança, como explorado em Godley e Lavoie (2012)[cap 4]. Assim, pode-se afirmar que a inclusão de um ativo financeiro acumulável por meio de poupança detido por duas classes torna o Teorema de Pasinetti (1962) invalido.

Destaca-se que a não verificação do paradoxo da poupança é mais robusta no caso de elevações nas propensões dos capitalistas do que nas propensões dos trabalhadores mais qualificados, uma vez que os capitalistas têm propensão a consumir mais baixa que os trabalhadores mais qualificados, evidenciando um efeito riqueza mais significativo. Contudo, esse resultado depende de um forte efeito riqueza. Como visto no capítulo anterior, se a fonte de demanda derivada da riqueza for pequena, há validade do paradoxo da poupança no longo prazo. Tal condição é verificada quando a propensão a consumir sobre a riqueza é menor que um certo limiar.

O resultado sobre o paradoxo da poupança encontrado nesta dissertação é dife- 
rente de Brochier e Silva (2018), que fazem um modelo Stock Flow Consistent com o supermultiplicador (Serrano e Freitas (2017)), em que as famílias também alocam sua riqueza em títulos públicos. Em Brochier e Silva (2018), a riqueza só afeta diretamente a demanda agregada por um canal, o consumo direto da riqueza, ou seja, o governo gasta independentemente da sua arrecadação tributária e a propensão a consumir sobre a renda financeira é zero.

Além disso, neste trabalho, não vale o paradoxo dos custos, ao contrário do que ocorre em Brochier e Silva (2018). Este efeito, assim como no caso do paradoxo da poupança, é consequência dos quatro canais pelos quais a riqueza financeira afeta a demanda agregada.

Como no regime de demanda profit-led os trabalhadores mais qualificados têm uma riqueza maior que no regime de demanda wage-led, a importância da riqueza desta classe no primeiro regime é mais relevante. É por esse motivo que, paradoxalmente, no regime profit-led, são necessárias configurações mais plausíveis de parâmetros de forma a validar o paradoxo dos custos no longo prazo. Repare que para o paradoxo dos custos valer no longo prazo há dois caminhos distintos. O primeiro é fortalecer a riqueza dos trabalhadores como fonte importante na demanda. O segundo, da mesma forma que no paradoxo da poupança, é retirar a força da fonte da riqueza na demanda de ambas as classes. Dessa maneira, o aumento da fonte de demanda derivada de salários e lucros é suficiente para compensar a queda na fonte derivada da riqueza.

Uma maior igualdade na distribuição de salários tem efeitos diversos na utilização de capacidade, a depender do regime de demanda. No regime wage-led, a maior parcela dos salários dos trabalhadores menos qualificados na renda de salários eleva a utilização de capacidade, enquanto ocorre o oposto no regime profit-led. Este resultado, contudo, é o menos robusto a alterações nos parâmetros.

Aumentos do gasto público via redução do superávit primário elevam a utilização de capacidade. Aqui, além do impulso inicial na injeção de demanda, o aumento da renda das classes também eleva sua riqueza, impulsionando ainda mais o aumento da demanda. Já aumentos na taxa de juros, assim como em Godley e Lavoie (2012) também ampliam a utilização ao elevar a renda financeira das famílias e, portanto, a riqueza. Tal resultado foi observado uma vez que a taxa de juros apenas eleva a renda. Contudo, é possível contrabalancear esse efeito ao aprimorar o modelo e fazer com que a taxa de juros impacte negativamente o crédito, o investimento ou mesmo o valor dos ativos.

Cabe destacar como essas mudanças nos parâmetros impactam a parcela dos trabalhadores na distribuição de riqueza e a na repartição líquida da renda. Como visto no capítulo 3, aumentos nas propensões a consumir dos trabalhadores mais qualificados reduzem a sua proporção na renda e riqueza financeira totais. Esse resultado é diferente 
de Palley (2016) e Dutt (2016). Nos dois modelos, como a riqueza é apenas de capital produtivo, o efeito no crescimento do estoque de capital pode ser tal que a proporção da riqueza dos trabalhadores se eleva.

Ampliações na parcela de salários na renda e uma maior desigualdade salarial, ao aumentarem a renda dos trabalhadores mais qualificados, elevam a parcela dos trabalhadores na renda e na riqueza financeira. A queda no superávit primário também aumenta a parcela dos trabalhadores na renda e na riqueza financeira totais, pois o aumento da utilização é mais significativo nos rendimentos desta classe.

Por fim, assim como em Taylor et al. (2014) e Piketty et al. (2017), mostrou-se como é difícil aumentar a parcela dos trabalhadores na distribuição de riqueza. Como apresentado na discussão do capítulo 3, elevações na parcela de salários e na tributação sobre a renda e riqueza dos capitalistas têm efeito pouco significativo na distribuição de riqueza. Somente com apropriações da riqueza dos capitalistas e transferência desta para os trabalhadores é possível modificar significativamente a distribuição de riqueza em prol dos trabalhadores. 
Apêndices 



\section{.1 Apêndice}

\section{.1.1 Utilização de Capacidade}

$$
u=\frac{\Phi_{1}}{\Phi_{2}}
$$

So that,

$$
\begin{gathered}
\Phi_{1}=\left(r _ { t } \left(b_{h, t-2}\left(\beta_{h, t}\left(1-\tau_{B, t}\right)+\tau_{B, t}\right)+b_{c, t-2}\left(\beta_{c, t}\left(1-\tau_{B, t}\right)+\tau_{B, t}\right)+v_{h, t-2}\left(\theta_{h, t}+\tau_{V, t}\left(1-\beta_{h, t}\right)\right)\right.\right. \\
+v_{c, t-2}\left(\theta_{c, t}+\tau_{V, t}\left(1-\beta_{c, t}\right)\right)+\gamma_{0, t}\left(1-\beta_{c, t}\right) \\
\Phi_{2}=1-\left\{\psi_{W, t}\left(\psi_{L, t}+\left(1-\psi_{L, t}\right)\left(\beta_{h, t}\left(1-\tau_{W, t}\right)+\tau_{W, t}\right)\right)+\right. \\
\left.\left(1-\psi_{W, t}\right)\left(\beta_{c, t}\left(1-\tau_{\pi, t}\right)+\tau_{\pi, t}+\gamma_{1, t}\left(1-\beta_{c, t}\right)\right)+\gamma_{2, t}\left(1-\beta_{c, t}\right)+\omega_{t}\right\}
\end{gathered}
$$





\section{Referências}

AGHION, P.; BOLTON, P. A theory of trickle-down growth and development. Review of Economic Studies, v. 64, n. 2, p. 151-172, 1997. Citado na página 31.

ALTISSIMO, F. et al. Wealth and asset price effects on economic activity. [S.l.], 2005. Citado 2 vezes nas páginas 41 e 67.

AMADEO, E. Expectations in a steady state model of capacity utilization. [S.1.], 1987. Citado 5 vezes nas páginas 33, 35, 47, 61 e 108.

ANDO, A.; MODIGLIANI, F. The life cycle hypothesis of saving: Aggregate implications and tests. American Economic Review, n. 53, p. 55-84, 1963. Citado na página 39.

BANERJEE, A. V.; NEWMAN, A. F. Risk-bearing and the theory of income distribution. The Review of Economic Studies, v. 58, n. 2, p. 211-235, 1991. Citado na página 31.

BARBA, A.; PIVETTI, M. Rising household debt: Its causes and macroeconomic implications - a long-period analysis. Cambridge Journal of Economics, CPES, v. 33, n. 1, p. 113-137, 2009. Citado na página 37.

BARBOSA-FILHO, N. H.; TAYLOR, L. Distributive and demand cycles in the us economy - a structuralist goodwin model. Metroeconomica, Wiley Online Library, v. 57, n. 3, p. 389-411, 2006. Citado na página 39.

BARRELL, R.; COSTANTINI, M.; MECO, I. Housing wealth, financial wealth, and consumption: New evidence for italy and the uk. International Review of Financial Analysis, v. 42, n. C, p. 316-323, 2015. Citado na página 67.

BHADURI, A.; LASKI, K.; RIESE, M. A model of interaction between the virtual and the real economy. Metroeconomica, v. 57, n. 3, p. 412-427, 2006. Citado na página 41.

BHADURI, A.; MARGLIN, S. Unemployment and the real wage: the economic basis for contesting political ideologies. Cambridge journal of Economics, JSTOR, v. 14, n. 4, p. 375-393, 1990. Citado 4 vezes nas páginas 35, 36, 49 e 61.

BIVENS, J.; MISHEL, L. The pay of corporate executives and financial professionals as evidence of rents in top 1 percent incomes. Journal of Economic Perspectives, v. 27, n. 3, p. 57-78, 2013. Citado na página 50.

BLECKER, R. A. Open economy models of distribution and growth. A Modern Guide to Keynesian Macroeconomics and Economic Policies, Edward Elgar Cheltenham, UK, p. 215-39, 2011. Citado na página 37.

BOONE, L.; GIORNO, C.; RICHARDSON, P. Stock Market Fluctuations and Consumption Behaviour: Some Recent Evidence. [S.l.], 1998. Citado 2 vezes nas páginas 41 e 67. 
BROCHIER, L.; SILVA, A. C. M. e. A supermultiplier stock-flow consistent model: the "return" of the paradoxes of thrift and costs in the long run? Cambridge Journal of Economics, p. bey008, 2018. Citado na página 109.

CARVAlHO, L.; REZAI, A. Personal income inequality and aggregate demand. Cambridge Journal of Economics, CPES, p. beu085, 2015. Citado 4 vezes nas páginas $31,37,38$ e 39 .

CATTE, P. et al. Housing markets, wealth and the business cycle. n. 394, 2004. Citado 2 vezes nas páginas 41 e 67.

CAVERZASI, E.; GODIN, A. Post-keynesian stock-flow-consistent modelling: a survey. Cambridge Journal of Economics, v. 39, n. 1, p. 157-187, 2015. Citado na página 52.

DAVIS, M. A.; PALUMBO, M. G. A primer on the economics and time series econometrics of wealth effects. [S.1.], 2001. Citado na página 41.

DUESENBERRY, J. H. Book. Income, saving and the theory of consumer behavior. [S.l.]: Harvard University Press Cambridge, 1949. 128 p. Citado na página 39.

DUTT, A. Macroeconomic theory after the crisis. Review of Radical Political Economics, v. 43, n. 3, p. 310-316, 2011. Citado 3 vezes nas páginas 37, 40 e 41.

DUTT, A. Power, uncertainty and income distribution: Towards a theory of crisis. Mimeo, 2011. Citado na página 52.

DUTT, A. Kaleckian growth yheory: an introduction. Metroeconomica, v. 63, n. 1, 2012. Citado na página 33.

DUTT, A. K. Stagnation, income distribution and monopoly power. Cambridge Journal of Economics, v. 8, n. 1, p. 25-40, 1984. Citado 4 vezes nas páginas 33, 34, 36 e 57.

DUTT, A. K. Growth, distribution and capital ownership: Kalecki and pasinetti revisited. Oxford University Press, p. 130-45, 1990. Citado 3 vezes nas páginas 13, 15 e 31.

DUTT, A. K. Unproductive'sectors and economic growth: A theoretical analysis. Review of Political Economy, Taylor \& Francis, v. 4, n. 2, p. 178-202, 1992. Citado na página 37 .

DUTT, A. K. Growth and distribution in heterodox models with managers and financiers. Metroeconomica, v. 67, n. 2, p. 364-396, 2016. Citado 6 vezes nas páginas 31, $37,46,49,51$ e 110 .

FURTADO, C. Aventuras de um economista brasileiro. In: Essencial Celso Furtado. [S.l.]: Penguin, 2013. Citado na página 11.

GALOR, O.; ZEIRA, J. Income Distribution and Macroeconomics. [S.l.], 1989. Citado 2 vezes nas páginas 31 e 40.

GARBINTI, B.; GOUPILlE-LEBRET, J.; PIKETTY, T. Accounting for Wealth Inequality Dynamics: Methods, Estimates and Simulations for France (1800-2014). [S.1.], 2017. Citado 2 vezes nas páginas 29 e 107. 
GODLEY, W.; CRIPPS, F. Book. Macroeconomics. [S.l.]: Oxford University Press, 1983. 320 p. Citado na página 52.

GODLEY, W.; LAVOIE, M. Monetary economics: an integrated approach to credit, money, income, production and wealth. [S.l.]: Springer, 2012. Citado 4 vezes nas páginas $53,57,108$ e 109.

GODLEY, W.; ZEZZA, G. Book. A Simple Real Stock Flow Model Illustrated with the Danish Economy. [S.1.]: University of Cambridge, 1989. Citado na página 52.

GOODWIN, R. M. A growth cycle model. Socialism, Capitalism, and Economic Growth, Cambridge University Press, Cambridge, 1967. Citado na página 46.

GUPTA, K. L. Differentiated interest rate and kaldor-pasinetti paradoxes. Kyklos, v. 29, n. 2, p. 310-14, 1976. Citado na página 44.

HARCOURT, G. C. et al. The Cambridge Post-Keynesian School of Income and Wealth Distribution. 2013. Citado na página 44.

HEIN, E.; VOGEL, L. Distribution and growth reconsidered: empirical results for six oecd countries. Cambridge journal of Economics, CPES, v. 32, n. 3, p. 479-511, 2008. Citado na página 37.

HICKS, J. Book. The crisis in Keynesian economics. [S.l.]: Blackwell Oxford [Eng.], 1974. 85 p. Citado na página 40.

HUNT, E. K. História do Pensamento Econômico - Uma Perspectiva Crítica. [S.1.]: Elsevier - Campus, 1981. Citado na página 39.

IPEA. Equidade fiscal no brasil: impactos distributivos da tributa c ao e do gasto socil. Comunicado do IPEA, n. 92, 2011. Citado na página 30.

KALDOR, N. Alternative theories of distribution. The Review of Economic Studies, JSTOR, v. 23, n. 2, p. 83-100, 1955. Citado 7 vezes nas páginas 13, 15, 31, 32, 42, 43 e 107.

KALECKI, M. Studies in economic dynamic. [S.l.]: G. Allen Unwin ltd, 1943. Citado na página 33.

KALECKI, M. Three ways to full employment. In: The Economics of Full Employment; Six Studies in Applied Economics. [S.l.]: B. Blackwell, 1944. Citado na página 33.

KALECKI, M. Theory of Economic Dynamics: An Essay on Cyclical and Long-Run Changes in Capitalist Economy,. [S.l.: s.n.], 1954. Citado 4 vezes nas páginas 33, 37, 46 e 52 .

KEYNES, J. M. The General Theory of Employment, Interest and Money. [S.1.]: Macmillan, 1936. 14th edition, 1973. Citado 2 vezes nas páginas 33 e 52.

LAVOIE, M. The kaleckian model of growth and distribution and its neo-ricardian and neo-marxian critiques. Cambridge Journal of Economics, v. 19, n. 6, p. 789-818, 1995. Citado na página 33. 
LAVOIE, M. Unproductive outlays and capital accumulation with target-return pricing. Review of Social Economy, Taylor \& Francis, v. 54, n. 3, p. 303-322, 1996. Citado na página 37.

LAVOIE, M. Post-Keynesian economics: new foundations. [S.1.]: Edward Elgar Publishing, 2014. Citado 6 vezes nas páginas 33, 34, 35, 38, 39 e 64.

LEITE, F. P. Como o Grau de Desigualdade Afeta a Propensão Marginal a Consumir? Distribuição de Renda e Consumo das Famílias no Brasil a Partir dos Dados das POF 2002-2003 e 2008-2009. [S.l.], 2014. Citado na página 67.

LETTAU, M.; LUDVIGSON, S. Understanding trend and cycle in asset values: Reevaluating the wealth effect on consumption. American Economic Review, v. 94, n. 1, p. 276-299, 2004. Citado na página 41.

LUDVIGSON, S.; STEINDEL, C. How important is the stock market effect on consumption? Economic Policy Review, n. Jul, p. 29-51, 1999. Citado na página 41.

MARX, K. O capital: Critica da economia política: livro i. $18^{\text {a }}$ edicão. Traducão de Reginaldo Sant'anna. Rio de Janeiro: Civilizacão brasileira, v. 2, p. 966p, 2001. Citado na página 39.

MEdeIROS, M.; CASTRO, F. A Composição Da Renda No Topo Da Distribuição: Evolução No Brasil Entre 2006 E 2012, a Partir De Informações Do Imposto De Renda. [S.1.]: Mimeo, 2016. Citado na página 30.

MEHRA, Y. P. The wealth effect in empirical life-cycle aggregate consumption equations. Economic Quarterly, p. 45-67, 2001. Citado na página 41.

MONTE, A. D. Grado di monopolio e sviluppo económico. Rivista Intemazionale di Scienze, v. 83, n. 3, p. 231-263, 1975. Citado na página 33.

NETO, J. H.; SABOIA, J. Distribuição funcional da renda no Brasil: análise dos resultados recentes e estimação da conta da renda. [S.1.], 2014. v. 18, 483-513 p. Citado na página 68.

PAIELLA, M. The stock market, housing and consumer spending: A survey of the evidence on wealth effects. Journal of Economic Surveys, v. 23, n. 5, p. 947-973, 2009. Citado na página 41.

PALlEY, T. Post Keynesian economics: debt, distribution and the macro economy. [S.1.]: Springer, 1996. Citado na página 44.

PALLEY, T. Wealth and wealth distribution in the neo-kaleckian growth model. Journal of Post Keynesian Economics, v. 34, n. 3, p. 453-474, 2012. Citado 10 vezes nas páginas $13,15,31,37,44,45,46,48,51$ e 53.

PALLEY, T. Cambridge and neo-kaleckian growth and distribution theory: comparison with an application to fiscal policy. Review of Keynesian Economics, v. 1, n. 1, p. 79-104, 2013. Citado 3 vezes nas páginas 31, 42 e 45.

PALLEY, T. The middle class in macroeconomics and growth theory: a three-class neo-kaleckian-goodwin model. Cambridge Journal of Economics, v. 39, n. 1, p. 221-243, 2015. Citado na página 37. 
PALLEY, T. Inequality and Growth in Neo-Kaleckian and Cambridge Growth Theory. [S.l.], 2016. Citado 6 vezes nas páginas 31, 37, 46, 48, 51 e 110.

PALLEY, T. I. Rethinking wage vs. profit-led growth theory with implications for policy analysis. [S.1.], 2014. Citado 2 vezes nas páginas 31 e 64.

PALLEY, T. I. The middle class in macroeconomics and growth theory: a three-class neo-kaleckian-goodwin model. Cambridge Journal of Economics, CPES, v. 39, n. 1, p. 221-243, 2015. Citado 4 vezes nas páginas 31, 38, 39 e 61.

PALLEY, T. I. et al. Inside debt and economic growth: a neo-kaleckian analysis. Chapters, Edward Elgar, 2010. Citado na página 37.

PASINETTI, L. L. Rate of profit and income distribution in relation to the rate of economic growth. Review of Economic Studies, v. 29, n. 4, p. 267-279, 1962 . Citado 9 vezes nas páginas 13, 15, 31, 32, 42, 43, 102, 107 e 108.

PIKETTY, T. Capital in the twenty-first century. Belknap Press of Harvard University Press Cambridge, MA, 2014. Citado 5 vezes nas páginas 13, 15, 29, 50 e 107.

PIKETTY, T. et al. Global Inequality Dynamics: New Findings from WID.world. [S.1.], 2017. Citado 3 vezes nas páginas 29, 30 e 110.

PIKETTY, T.; ZUCMAN, G. Wealth and inheritance in the long run. In: ATKINSON, A. B.; BOURGUIGNON, F. (Ed.). Handbook of Income Distribution. [S.1.]: Elsevier, 2015. v. 2, p. 1303 - 1368. Citado 2 vezes nas páginas 29 e 107.

RICARDO, D. On the Principles of Political Economy and Taxation. [S.1.]: McMaster University Archive for the History of Economic Thought, 1821. Citado na página 39.

ROWTHORN, B. Demand, real wages and economic growth. [S.1.]: North East London Polytechnic, 1981. Citado 5 vezes nas páginas 33, 34, 36, 48 e 57.

RYOO, S. Household debt and housing bubbles: a minskian approach to boom-bust cycles. Journal of Evolutionary Economics, v. 26, n. 5, p. 971-1006, 2016. Citado na página 41.

SALVADOR, E. As Implicações do Sistema Tributário Brasileiro nas Desigualdades de Renda. [S.1.], 2017. Citado na página 30.

SANTOS, C. H. D.; ZEZZA, G. A simplified, benchmark, stock-flow consistent post-keynesian growth model. Metroeconomica, v. 59, n. 3, p. 441-478, 2008. Citado na página 52.

SERRANO, F.; FREITAS, F. The sraffian supermultiplier as an alternative closure for heterodox growth theory. European Journal of Economics and Economic Policies: Intervention, v. 14, n. 1, p. 70-91, 2017. Citado na página 109.

SILVA, A. C. M. e.; SANTOS, C. H. D. Peering over the edge of the short period? the keynesian roots of stock-flow consistent macroeconomic models. Cambridge Journal of Economics, v. 35, n. 1, p. 105-124, 2011. Citado na página 52.

SILVEIRA, F. G. et al. Fiscal Equity: Distributional Impacts of Taxation and Social Spending in Brazil. [S.1.], 2013. Citado na página 30. 
SLACALEK, J. What Drives Personal Consumption?: The Role of Housing and Financial Wealth. [S.1.], 2006. Citado na página 41.

SMITH, A. An Inquiry to the Nature and Causes of the Wealth of Nations. [S.l.: s.n.], 1776. Citado na página 39.

SOUSA, R. M. Wealth effects on consumption: evidence from the euro area. [S.l.], 2009. Citado 2 vezes nas páginas 41 e 67.

TAVANI, D.; VASUDEVAN, R. Capitalists, workers, and managers: Wage inequality and effective demand. Structural Change and Economic Dynamics, Elsevier, v. 30, p. 120-131, 2014. Citado 2 vezes nas páginas 37 e 38.

TAYLOR, L. Book. Reconstructing Macroeconomics: Structuralist Proposals and Critiques of the Mainstream. [S.1.]: Harvard University Press, 2004. 456 p. Citado na página 46.

TAYLOR, L.; OMER, O.; REZAI, A. Wealth Concentration, Income Distribution, and Alternatives for the USA. [S.1.], 2015. Citado na página 30.

TAYLOR, L. et al. Wage Increases, Transfers, and the Socially Determined Income Distribution in the USA. [S.l.], 2014. Citado 2 vezes nas páginas 30 e 110.

TOBIN, J. A general equilibrium approach to monetary theory. Journal of Money, Credit and Banking, v. 1, n. 1, p. 15-29, 1969. Citado na página 41.

TOBIN, J.; BRAINARD, W. C. Asset Markets and the Cost of Capital. [S.1.], 1976. Citado na página 46.

TRIGG, A. B. On the relationship between kalecki and the kaleckians. Journal of Post Keynesian Economics, Routledge, v. 17, n. 1, p. 91-109, 1994. Citado na página 33.

VEBLEN, T. A teoria da classe ociosa: um estudo econômico das instituições. [S.1.]:

Nova Cultural, 1988. Citado na página 39.

ZELDES, S. Consumption and liquidity constraints: An empirical investigation. Journal of Political Economy, v. 97, n. 2, p. 305-46, 1989. Citado na página 67. 